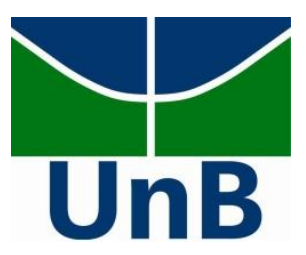

UNIVERSIDADE DE BRASÍLIA - UNB

FACULDADE DE CEILÂNDIA - FCE

PROGRAMA DE PÓS-GRADUAÇÃO EM CIÊNCIA E TECNOLOGIA

MARCELA FONSECA JONAS

AGRICULTURA E SAÚDE: UMA ABORDAGEM SOBRE O PERFIL DE SAÚDE DO AGRICULTOR DA ZONA RURAL DE BRAZLÂNDIA.

BRASÍLIA - DF

2015 
MARCELA FONSECA JONAS

AGRICULTURA E SAÚDE: UMA ABORDAGEM SOBRE O PERFIL DE SAÚDE DO AGRICULTOR DA ZONA RURAL DE BRAZLÂNDIA.

Dissertação de Mestrado apresentada ao Programa de Pós-Graduação em Ciências e Tecnologias em Saúde da Faculdade de Ceilândia - Universidade de Brasília como exigência para obtenção do título de Mestre.

ORIENTADORA: Prof ${ }^{a}$. Dra. MARIA HOSANA CONCEIÇÃO

CO-ORIENTADORA: Prof ${ }^{a}$. Dra. ALDIRA G. DUARTE DOMÍNGUEZ

BRASÍLIA - DF

2015 
MARCELA FONSECA JONAS

\title{
AGRICULTURA E SAÚDE: UMA ABORDAGEM SOBRE O PERFIL DE SAÚDE DO AGRICULTOR DA ZONA RURAL DE BRAZLÂNDIA.
}

Dissertação de Mestrado apresentada pela aluna Marcela Fonseca Jonas do Programa de Pós-Graduação em Ciências e Tecnologias em Saúde, tendo obtido o conceito de , conforme a apreciação da Banca Examinadora.

Aprovado em de 2015.

BANCA EXAMINADORA

Prof $^{\mathrm{a}}$. Dra. Maria Hosana Conceição - UnB

Orientadora

\author{
Prof $^{\text {a }}$. Dra. Eloisa Dutra Caldas - UnB \\ Membro Examinador
}

Prof $^{\mathrm{a}}$. Dra. Clélia Maria Ferreira Parreira - UnB

Membro Examinador
Prof. Dr. João Paulo Chieregato Matheus - UnB
Membro suplente

BRASÍLIA - DF

2015 
Dedico esse trabalho a Deus por me permitir fazê-lo. Aos meus pais Marcelo Menezes Jonas e Clívia Jarvis Fonseca Pereira Jonas, base de tudo. Aos meus familiares e amigos que de forma direta ou indiretamente acreditaram em meu esforço $e$ aos agricultores familiares $e$ moradores da Zona Rural de Brazlândia-DF, objetivo maior de toda atividade científica. 


\section{AGRADECIMENTOS}

Agradeço primeiramente a Deus meu guia protetor, por ter me dado a vida e estar me iluminando em todos os caminhos em que sigo;

Aos Meus pais e Irmãos que são a razão do meu viver, por seu amor e confiança em mim, exemplo de caráter e humildade - meu amor maior;

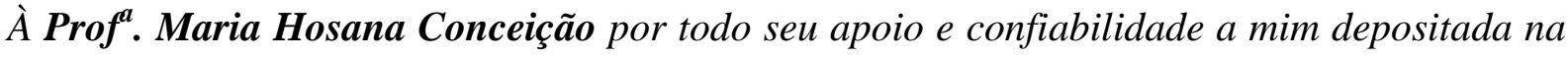
construção e orientação deste trabalho;

À Prof ${ }^{a}$. Aldira Guimarães Duarte Domínguez, por seus ensinamentos e competência;

Aos Meus familiares e Amigos em que sempre tiveram uma palavra de apoio e carinho;

Infinita é minha alegria, por ter Mariana Jonas e Mila Jonas como primas, incentivando-me durante esta caminhada.

Ao presidente da Empresa de Assistência Técnica e Extensão Rural de Brazlândia (Emater/DF) e ao chefe do Núcleo de Saúde Rural do Distrito Federal na pessoa de Marcelo Piccin e Sergio Eduardo Gonçalves, respectivamente, pela permissão e realização da pesquisa.

Acredito que nenhum indivíduo desenvolve-se por si mesmo. Por esse motivo, apresento meus agradecimentos a Todas as pessoas com as quais tive a experiência de uma interação no decorrer da minha vida e por aquilo que me concederam em matéria de enriquecimento;

Nessa caminhada, com muitos obstáculos, encontrei no incentivo deles, esperança, coragem, determinação e fé. 


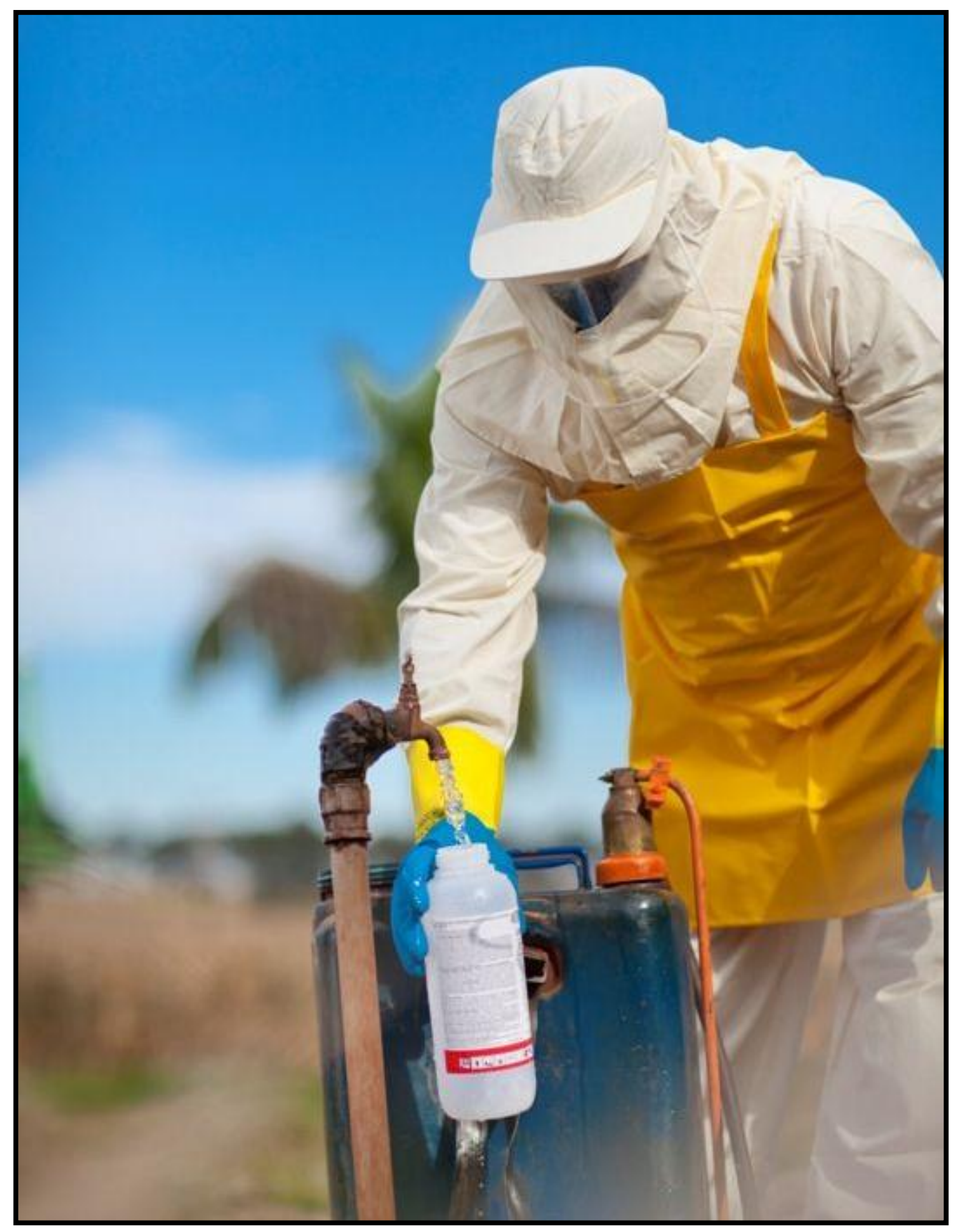


BANCA EXAMINADORA ii

FIGURAS, TABELAS E ANEXOS vii

SÍMBOLOS, SIGLAS E ACRÔNIMOS viii

RESUMO ix

1 INTRODUÇÃO 12

1.1 CONTEXTUALIZAÇÃO, JUSTIFICATIVA E OBJETIVOS DA PESQUISA 13

2 REFERENCIAL TEÓRICO 17

2.1 AGROTÓXICOS: ASPECTOS LEGAIS, DEFINIÇÃO E CLASSIFICAÇÃO 18

2.2 PRINCIPAIS AGROTÓXICOS UTILIZADOS NAS CULTURAS DA REGIÃO DA

CHAPADINHA, ZONA RURAL DE BRAZLÂNDIA - DISTRITO FEDERAL 24

2.3 OS EFEITOS DOS AGROTÓXICOS 27

2.4 PERCEPÇÃO DE RISCOS À SAÚDE NO USO DE AGROTÓXICOS 33

3 METODOLOGIA $\quad 38$

3.1 TIPO DE PESQUISA 39

3.2 PARTICIPANTES, LOCAL E PERÍODO DA PESQUISA 39

3.3 INSTRUMENTO PARA A COLETA DE DADOS E PROCEDIMENTOS DA PESQUISA

3.4 ANÁLISE DOS DADOS

3.5 ASPECTOS ÉTICOS DA PESQUISA 43

3.6 FINANCIAMENTO DA PESQUISA

4 RESULTADOS E DISCUSSÃO 44

4.1 CARACTERIZAÇÃO DOS SUJEITOS DA PESQUISA 45

4.2 NÚCLEO DE SENTIDO I: O TRABALHADOR RURAL E O CONTATO COM AGROTÓXICOS 46

4.3 NÚCLEO DE SENTIDO II: SAÚDE DO AGRICULTOR 53

5 CONSIDERAÇÕES FINAIS

REFERÊNCIAS

$\begin{array}{ll}\text { APÊNDICES } & 77\end{array}$

$\begin{array}{ll}\text { ANEXOS } & 80\end{array}$ 
Figura 1. Região da Chapadinha, em Brazlândia 16

Figura 2. Tríplice lavagem das embalagens dos agrotóxicos _ 23

Figura 3. Concentraçäo da enzima colinesterase plasmática 55

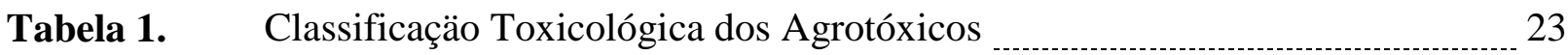

Tabela 2. Dados sóciodemográficos dos entrevistados. Brazlândia. Brasil, $2012 \quad 46$

Tabela 3. Agrotóxicos Utilizados Pelos Agricultores da Chapadinha - Zona Rural de Brazlândia - DF

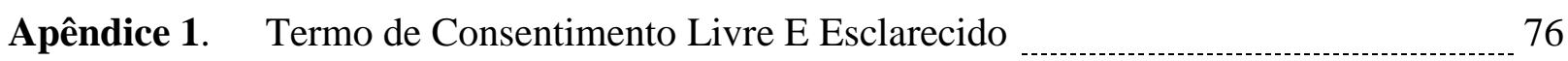

Apêndice 2. Entrevista Semi-estruturada 77

Anexo A Parecer do comitê de ética 79

Anexo B - Publicação 82 


\section{SÍMBOLOS, SIGLAS E ACRÔNIMOS}

AChE -Acetilcolinesterase

Anvisa - Agência Nacional de Vigilância Sanitária

BChE - Butirilcolinesterase

CIAT/DF - Centro de Informação e Assistência Toxicológica do Distrito Federal

DDT- Dicloro DifenilTricloroetano

DF - Distrito Federal

DL - Dosagem Letal

Emater/DF - Empresa de Assistência Técnica e Extensão Rural do Distrito Federal EPI - Equipamento de Proteção Individual

ETU - Etilenotiouréia

Ibama - Instituto Brasileiro do Meio Ambiente e Recursos Naturais Renovaveis

PARA - Programa de Análise de Resíduos de Agrotóxicos em Alimentos

PPA - Potencial de Periculosidade Ambiental

SINITOX - Sistema Nacional de Informação Tóxico Farmacológico 


\section{RESUMO}

JONAS, M. F. Agricultura e saúde: uma abordagem sobre o perfil de saúde do agricultor da zona rural de Brazlândia. Brasília, 2015. 98 f. Dissertação de Mestrado - Programa de Pós-Graduação em Ciências e Tecnologias em Saúde da Faculdade de Ceilândia Universidade de Brasília. Brasília-DF, 2015.

O uso de agrotóxico aumentou significativamente no Brasil, na última década, crescendo duas vezes mais que o restante do mundo e ocupando o lugar de maior consumidor desde 2008. A Associação Brasileira da Indústria Química destacou um aumento de 10,3\% nas vendas de agrotóxicos no Brasil em 2013. O uso destes compostos agrícolas promoveu a modernização do campo conhecida como Revolução Verde, o que legitima o Brasil como um dos maiores países agroexportadores. Um dos grandes desafios desta realidade consiste em reduzir os efeitos do agrotóxico na saúde dos agricultores em particular e da população em geral. Objetivo: Compreender a percepção do agricultor familiar da zona rural da Chapadinha sobre a relação entre o manuseio do agrotóxico e a saúde. Metodologia: Pesquisa quali-quantitativo de natureza transversal, desenvolvido na Zona Rural de Brazlândia - região da Chapadinha. A amostra foi constituída, desde a perspectiva da pesquisa qualitativa, por dez entrevistados e na quantitativa por 66 amostras sanguíneas dos trabalhadores da região. O instrumento de coleta de dados contemplou perguntas objetivas e subjetivas relacionadas à temática do estudo. Para o tratamento qualitativo dos dados utilizou-se a técnica de análise de conteúdo na modalidade temática. Foi realizado também estudo dos exames toxicológicos para a determinação da Butirilcolinesterase (BChE) nos trabalhadores. Os resultados obtidos das amostras de sangues foram tabelados no Software Excel 2007. A pesquisa foi submetida e aprovada pelo Comitê de Ética em Pesquisa com Seres Humanos da Faculdade de Ciências da Saúde da UnB sob o Parecer número 943.423. Resultados: A análise do conteúdo das entrevistas possibilitou a elaboração dos núcleos de sentido: 1) "O trabalhador rural e o contato com agrotóxicos"; 2) "Saúde do agricultor". Para possibilitar uma discussão mais aprofundada acerca dos referidos núcleos, mediante a técnica de Análise de Conteúdo na Modalidade Temática, desta emergiram quatro categorias, sendo duas provenientes de cada núcleo permitindo assim um melhor direcionamento do estudo, são elas: "As percepções dos agricultores sobre a exposição ao agrotóxico"; "Cuidados individuais e coletivos adotados pelos trabalhadores"; "Concepção dos agricultores sobre a saúde"; "Sinais e sintomas relatados pelos trabalhadores". Conclusão: Percebeu-se entre os agricultores da Chapadinha a necessidade de mais sensibilização para o manuseio correto do agrotóxico nas lavouras, sendo necessário desenvolver ações mais assertivas para evitar possíveis contaminações e intoxicações. Intensificar os debates sobre o uso correto dos EPI's ainda faz-se necessário, tendo em vista que muito deste trabalhadores apresentam sinais e sintomas próprios da contaminação por agrotóxico.

PALAVRAS-CHAVE: Saúde pública, população rural, butirilcolinesterase. 
The use of pesticides has increased significantly in Brazil over the past decade, growing twice as fast as the rest of the world and taking over for most consumers since 2008. The Brazilian Association of Chemical Industry highlighted an increase of $10.3 \%$ in pesticide sales in Brazil in 2013. the use of agricultural compounds promoted the modernization of the countryside known as the Green Revolution, which legitimizes Brazil as one of the largest agro-exporting countries. One of the great challenges of this reality is to reduce the effects of pesticides on the health of farmers in particular and the general population. Objective: To understand the perception of family farmer from rural Chapadinha on the relationship between the handling of pesticides and health. Methodology: qualitative and quantitative research, developed in the Rural Area of Brazlândia - Chapadinha the region. The sample , from the perspective of qualitative for 10 respondents and quantitative for 66 blood samples of workers in the region. The data collection instrument included objective and subjective questions related to the topic of study. For the qualitative data processing we used the content analysis technique in thematic modality. It was also conducted study of toxicology tests to determine the butyrylcholinesterase ( $\mathrm{BChE}$ ) in workers. The results of bloods samples were tabulated in Software Excel 2007. The study was submitted to and approved by the Ethics Committee on Human Research of the Health Sciences Faculty of UNB. Results: The content analysis of the interviews allowed the drafting of core meanings: 1) "The rural worker and contact with pesticides"; 2) "Health farmer". To enable further discussion of these cores through the content analysis technique in the Thematic mode, this four categories emerged, two from each core thus allowing better targeting of the study, they are: "The perceptions of farmers on exposure to pesticides "; "Individual and collective Care adopted by the workers"; "Received support and the perception of farmers on health"; "Signs and symptoms reported by workers." Conclusion: It was noticed among farmers in Chapadinha the need for more awareness of the proper handling of pesticides in crops, being necessary to develop more assertive action to prevent possible contamination and poisoning. More intense discussions on the proper use of PPE still it is necessary, given that much of this workers have own signs and symptoms of contamination by pesticides.

KEYWORDS: Public health, rural population, butyrylcholinesterase. 
1 INTRODUÇÃO 


\subsection{CONTEXTUALIZAÇÃO, JUSTIFICATIVA E OBJETIVOS DA PESQUISA}

O avanço científico e tecnológico empregado como processo de desenvolvimento econômico, impulsionado pela globalização mundial tem favorecido vários setores da economia, dentre eles o setor do agronegócio. O Brasil ocupa desde 2008 o primeiro lugar no mundo em consumo de insumos agropecuários, graças ao desenvolvimento das indústrias químicas, com a utilização de agrotóxicos e fertilizantes (RIGOTTO; ROCHA, 2014).

A Confederação da Agricultura e Pecuária do Brasil informa que em 2013 o agronegócio foi responsável por 22,8 \% do Produto Interno Bruto brasileiro e que nesse ano atingiu aproximadamente 1,5 trilhões de reais (CNA, 2014). Esses números só são possíveis devido à utilização de insumos agrícolas em grande escala.

Em termos conceituais, os agrotóxicos são compostos sintetizados em laboratórios ou de origem natural, utilizados, principalmente, na agricultura para controlar pragas e doenças provocadas por insetos e fungos que causam danos às plantações, contribuindo assim para o crescimento e o desenvolvimento da agricultura moderna (BRASIL, 2002). No entanto, as utilizações indevidas desses compostos químicos podem causar desequilíbrio no meio ambiente, além de serem responsáveis por vários problemas na saúde humana e animal (MATOS, 2010).

O emprego de compostos químicos para o controle de pragas na agricultura não é fato recente, pois há relatos da utilização desses produtos pelas antigas civilizações chinesas, gregas e romanas. Nesse período, esses povos já haviam percebido o poder do pó de enxofre no controle de insetos e ervas daninhas (SANTOS, 2002). Há indícios também do uso de compostos sulfurados, e compostos de arsênio antes do século XVII (BRAIBANTE; ZAPPE, 2012).

Porém o grande marco na história do agrotóxico ocorreu durante a Segunda Guerra Mundial (1939 - 1945), quando os inseticidas orgânicos sintéticos foram utilizados pra proteger os soldados localizados na África e Ásia, dos vetores transmissores de doenças como a doença-do-sono e malária. Nesse mesmo período, foram estimuladas novas pesquisa para o desenvolvimento de vários agrotóxicos que são usados ainda hoje (BRANCO, 2003).

Outro fato histórico envolvendo o uso indevido dos agrotóxicos aconteceu durante a Guerra do Vietnã (1975), quando aviões americanos despejaram 83 milhões de litros da substância desfolhante sobre as vegetações que camuflavam os soldados vietnamitas (SANTOS, 2002). 
Apesar dos agrotóxicos sintéticos terem sidos apresentados ao mundo na década de trinta, somente após a década de cinquenta, com o início da "Revolução Verde", foi que o consumo aumentou de maneira significativa, impulsionando o agronegócio para os patamares da atualidade. Também foi nesse período que os estudiosos começaram a analisar os efeitos negativos que os agrotóxicos causavam sobre o meio ambiente e a saúde humana (PINGALI, 2012).

Vale salientar que em meio ao arsenal tecnológico oferecido nos dias de hoje, o agrotóxico é a alternativa mais acessível para o aumento da produção agrícola, tendo em vista as necessidades sempre crescentes do consumo humano de produtos alimentícios (MASCARENHA; PESSOA, 2013).

Com a alegação de que os agrotóxicos seriam a "tábua da salvação" para o controle de pragas e doenças na agricultura, as fronteiras brasileiras foram abertas para utilização massiva de tais produtos (PINGALI, 2012). Como consequência o consumo de agrotóxico aumentou significativamente no Brasil, diante disso, o mercado brasileiro de agrotóxicos cresceu $190 \%$, enquanto o mercado mundial de agrotóxicos cresceu $93 \%$.

A Associação Brasileira da Indústria Química destacou um aumento de 10,3\% nas vendas de agrotóxicos no Brasil em 2013 e nos anos de 2011 e 2012 tais compostos foram responsáveis pela movimentação de US\$ 9,4 bilhões e US\$ 8,5 bilhões, respectivamente, no comércio brasileiro (ABIQUIM, 2014).

Embora esses compostos movimentem a economia do Brasil, não se pode negar que a utilização intensiva de agrotóxicos tem causado inúmeros problemas, tais como os impactos sociais e ambientais. Aliando a esses fatores está a falta de preparo dos trabalhadores rurais para lidar com estes compostos, o que contribui para sua exposição contínua ao agrotóxico (JACOBSON ; HACON; ALVARENGA et al., 2009).

No Distrito Federal, durante o período de julho de 2004 a dezembro de 2007, foram registrados 1.085 casos de intoxicações por agrotóxico ao Centro de Informação e Assistência Toxicológica do Distrito Federal - CIAT/DF, sendo registrados principalmente nos hospitais da zuna rural, onde o manuseio do produto é mais frequente devido aos riscos de pragas e doenças a que estão sujeitas as plantações (REBELO; CALDAS; HELIODORO et al., 2011).

A Chapadinha é uma região localizada na Zona Rural Brazlândia (Figura 1), se destaca no cultivo de morangos, ocupando o $6^{\circ}$ lugar no ranking brasileiro dos municípios 
produtores da fruta. Além disso, possui o mais importante agrossistema olerícola e frutífera do Distrito Federal - DF (BALLA; SANTOS; OLIVEIRA et al., 2011).

Considerando que a produção do morango tem grande importância econômica para região e por se tratar de uma cultura que necessita de grande dedicação e intensa mão de obra, parte significativa da população local tem a sua ocupação no trabalho agrícola, tornando essa região vulnerável à incidência de casos de intoxicação por agrotóxicos (LORENA, 2012). Deste modo reconhece-se a relevância e pertinência deste estudo tendo em vista os reais riscos a que os agricultores familiares e moradores da Zona Rural de Brazlândia estão expostos.

Para tanto, visamos responder o seguinte questionamento: Qual a percepção dos agricultores familiares sobre a relação entre o manuseio do agrotóxico e a saúde?

Nesse contexto, o presente trabalho teve como objetivo principal: Compreender a percepção do agricultor familiar da zona rural da Chapadinha sobre a relação entre o manuseio do agrotóxico e a saúde. Em relação aos objetivos específicos buscou-se: -Verificar os cuidados realizados pelos trabalhadores para proteger a saúde individual e coletiva; Identificar os sinais e sintomas relatados pelos trabalhadores rurais da Chapadinha; - Estudar a correlação dos resultados dos exames de sangue da butirilcolinesterase e o contato contínuo com o agrotóxico.

A partir do conhecimento da opinião dos usuários, possam ser sugeridas, desenvolvidas e implementadas estratégias para melhorar a realidade no que refere ao foco do estudo. Isso tornará possível subsidiar tanto o poder público, nas instituições municipais de saúde, agricultura e meio ambiente; como o setor privado e a sociedade civil na tomada de decisões que garantam a saúde desses trabalhadores, além de poder tornar-se referência para outras cidades e regiões brasileiras que se encontram em situação semelhante.

Além disso, esta pesquisa visou contribuir para o acervo de informações sobre a saúde dos trabalhadores e de seus familiares, da Zona Rural de Brazlândia, que praticam o uso de agrotóxicos.

Finalmente, neste trabalho, abordaram-se inicialmente questões específicas e correlatas ao manuseio do agrotóxico pelos agricultores familiares, os cuidados realizados pelos trabalhadores para proteger a saúde assim como os sinais e sintomas característicos do contato frequente com o produto químico. Posteriormente seguem os capítulos referentes à metodologia, resultados e discussões e as considerações finais obtidas nesta pesquisa. 


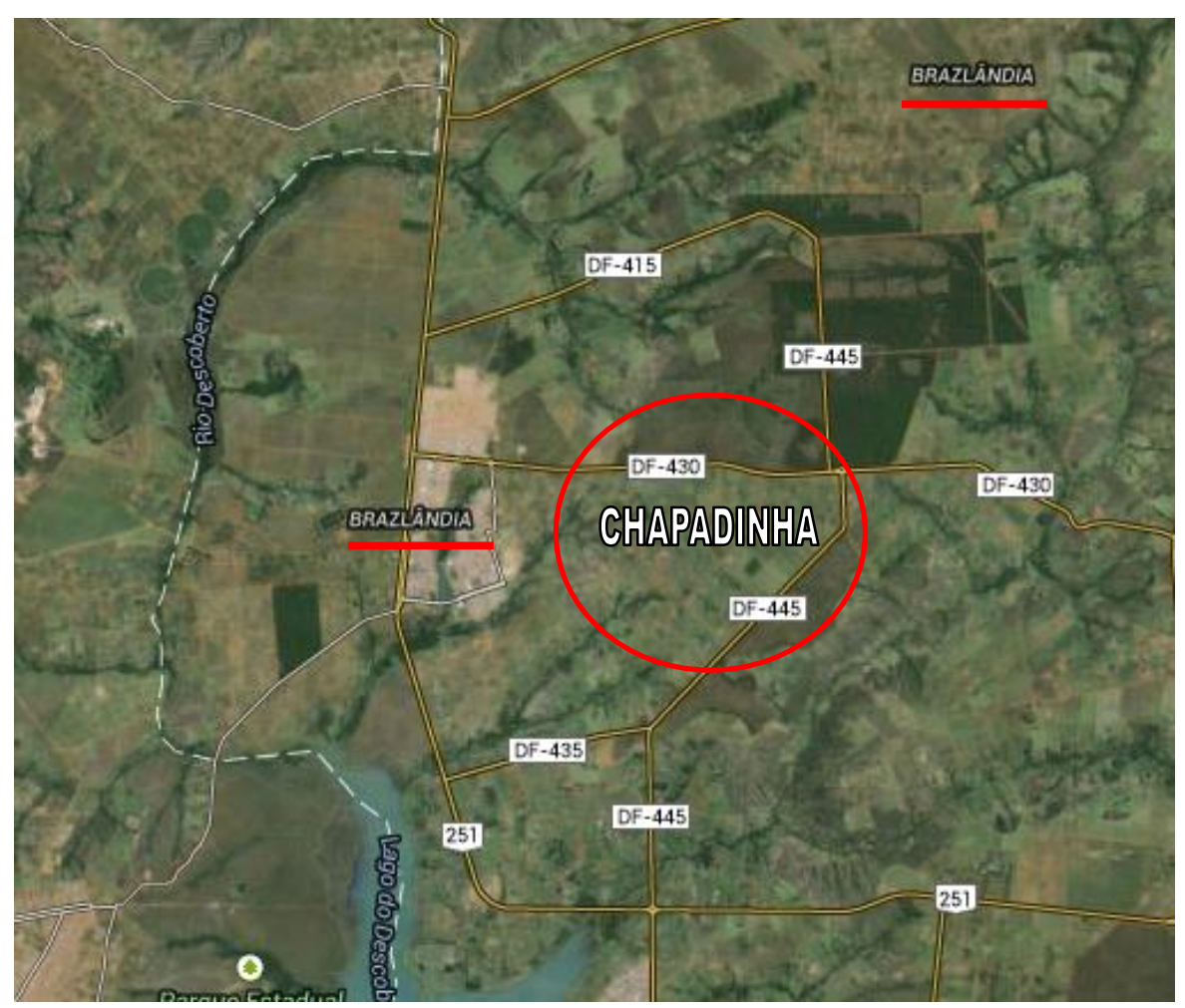

Figura 1. Região da Chapadinha, em Brazlândia. Fonte: Google Maps 
2 REFERENCIAL TEÓRICO 


\subsection{AGROTÓXICOS: ASPECTOS LEGAIS, DEFINIÇÃO E CLASSIFICAÇÃO}

No Brasil existem leis e regras a serem cumpridas para utilização adequada do agrotóxico. A Lei Federal nº 7.802 de 11 de julho de 1989, dispõe sobre os vários processos referentes à produção, embalagem e rotulagem, o transporte, o armazenamento, comercialização, utilização, importação, exportação, o destino final dos resíduos e das embalagens, o registro, a classificação, o controle, inspeção, fiscalização e dá outras providências (BRASIL, 2002).

A Lei foi regulamentada através do Decreto 98.816, no seu Artigo $2^{\circ}$, Inciso I, e define do termo agrotóxico como:

Os produtos e os componentes de processos físicos, químicos ou biológicos destinados ao uso nos setores de produção, armazenamento e beneficiamento de produtos agrícolas, nas pastagens, na proteção de florestas nativas ou implantadas e de outros ecossistemas e também em ambientes urbanos, hídricos e industriais, cuja finalidade seja alterar a composição da flora e da fauna, a fim de preservá-la da ação danosa de seres vivos considerados nocivos, bem como substâncias e produtos empregados como desfolhantes, dessecantes, estimuladores e inibidores do crescimento (BRASIL, 2002, p.1).

A mesma Lei define os componentes como "Os princípios ativos, os produtos técnicos, suas matérias primas, os ingredientes inertes e aditivos usados na fabricação de agrotóxicos e afins" e definem ainda afins como "os produtos e os agentes de processos físicos e biológicos que tenham a mesma finalidade dos agrotóxicos, bem como outros produtos químicos, físicos e biológicos, utilizados na defesa fitossanitária e ambiental, não enquadrados no Inciso" (BRASIL, 2002).

No período anterior à Constituição de 1988, esse grupo de produtos químicos era conhecido como defensivo agrícola, essa denominação excluía outros compostos, tais como os agentes utilizados nas campanhas sanitárias urbanas, para o controle de insetos e vetores causadores de doenças e epidemias.

Os defensivos agrícolas faziam parte da Portaria 3.214, de 8 de junho de 1978, que aprova as Normas Regulamentadoras relativas à Segurança e Medicina do Trabalho, especificamente da Norma Regulamentadora Rural $n^{\circ} 5$, que tratava da utilização de produtos químicos no trabalho rural. A mesma Norma, alterada durante o processo constituinte passa a tratar, a partir da data de sua promulgação, esse grupo de produtos químicos por agrotóxicos. Essa simples alteração na nomenclatura coloca em evidência a possibilidade de toxicidade desses produtos ao meio ambiente e à saúde humana (BRASIL, 2008). 
Segundo Organização das Nações Unidas para Alimentação e Agricultura (FAO), órgão das Nações Unidas os agrotóxicos são definidos como:

Qualquer substância, ou mistura de substância, usadas para prevenir, destruir ou controlar qualquer praga - incluindo vetores de doenças humanas e animais, espécies indesejadas de plantas ou animais, causadoras de danos durante (ou interferindo na) produção, processamento, estocagem, transporte ou distribuição de alimentos, produtos agrícolas, madeiras e derivados - ou que deva ser administrada para o controle de insetos, aracnídeos e outras pestes que acometem os corpos de animais de criação (FAO, 1999, p.4).

Para os agrotóxicos serem produzidos, exportados, importados, comercializados e utilizados torna-se necessário o registro prévio nas Instituições Governamentais juntamente com a necessidade do receituário agronômico prescrito e orientado por um profissional legalmente habilitado, de acordo com as diretrizes e exigências dos órgãos federais responsáveis pelos setores da saúde, do meio ambiente e da agricultura (BRASIL,2011).

Diante disso, a Legislação atribui como competência do Ministério da Agricultura Pecuária e Abastecimento realizar a avaliação da eficácia agronômica; à Agência Nacional de Vigilância Sanitária (Anvisa), de executar a avaliação e classificação toxicológica e ao Instituto Brasileiro do Meio Ambiente e dos Recursos naturais Renováveis (Ibama) avaliar e classificar o potencial de periculosidade ambiental. Os órgãos estaduais e do Distrito Federal, dentro de sua área de competência, devem realizar o controle e a fiscalização da comercialização e uso desses produtos na sua jurisdição (BRASIL, 2002).

Vale destacar que são realizados testes toxicológicos e físico-químicos com os agrotóxicos a fim de fundamentar qualquer alteração, restrição ou não registro, sendo dessa forma avaliados e classificados quanto a sua toxicidade ambiental e toxidade humana e em classes que variam de I a IV (PERES; MOREIRA; DUBOIS, 2003).

\subsubsection{Classificação dos agrotóxicos: ação ao organismo-alvo e composição química}

a) Inseticidas

Antigamente, para combater insetos eram utilizadas substâncias como o arsênio, o mercúrio e o tabaco; com a Segunda Guerra Mundial, foram produzidos gases bélicos, onde foi possível observar seu efeito contra insetos, surgindo assim os inseticidas. No ano de 1948, o cientista Paul Muller ganhou o Prêmio Nobel de Medicina por descobrir a arma mais eficaz de combate à malária, o DDT (Dicloro Difenil Tricloroetano) (ALVES FILHO, 2002). 
REFERENCIAL TEÓRICO

Os inseticidas são comumente classificados de acordo com sua estrutura química, tendo como principais grupo os Organoclorados, Organofosforados, Carbamatos e Piretróides (ECOBICHON, 2001).

Os Organoclorados são compostos que apresentam átomos de cloro em sua composição química. Por serem substâncias altamente tóxicas, de grande poder de acumulo na cadeia alimentar, de toxidade crônica, insolúveis em água e lipofílicos, os organoclorados passaram a ter uso proibido, não são mais produzidos no Brasil e em vários outros países.

Os Organofosforados apresentam ésteres do ácido fosfórico, com menor teor de toxidez comparado aos organoclorados, no entanto, são absorvidos pelo organismo humano através de todas as vias possíveis (respiratória, gastrointestinal, dérmica, por membranas de mucosas). Não são cumulativos, insolúveis em água, apresentam toxidade aguda (efeitos aparecem rapidamente no organismo) (EDDLESTON; BUCKLEY; EYER et al., 2008)

Quando o inseticida possui ésteres do ácido carbâmico são conhecidos como Carbamatos. Apresenta toxidade aguda média, baixo acúmulo no meio ambiente, são insolúveis em água, pouco absorvidos pelo organismo humano e bastante utilizados no controle de insetos (CLARK, 2006).

Os inseticidas conhecidos até os anos 80 possuíam um alto potencial tóxico, então surgiram os piretróides que possuem baixa toxicidade aguda em mamíferos e não são tão persistentes no ambiente. São inseticidas sintético similar às substâncias naturais piretrinas produzidas pelas flores do "filo" Chrysanthemum cinerariaefolium e $C$. coccineum (HIRATA, 1995).

De maneira geral, os inseticidas são compostos químicos apropriados para o combate de insetos que devastam as plantações e o meio ambiente. São usados constantemente em lavouras e em menor frequência em casas e indústrias.

b) Fungicidas

Os produtos responsáveis pelo controle de fungos fitopatogênicos, são os fungicidas. Podem ser classificados de acordo com o grupo químico em Inorgânicos, Ditiocarbamatos, Dinitrofenóis, Organomercuriais, Antibióticos, Trifenil estânico e Compostos Formilamina (ECOBICHON, 2001).

Os ditiocarbamatos são derivados do ácido ditiocarbâmico, que existem sob a forma de um pó branco ou amarelo-claro, de baixa toxicidade aguda, baixa volatilidade e 
REFERENCIAL TEÓRICO

solubilidade em solventes orgânicos. Como exemplo destes produtos encontram-se o Mancozeb, Maneb, Propineb, Ziram, Tiram e Zineb (THORN; LUDWIG, 1962).

O Mancozebe é uma mistura contendo $20 \%$ de manganês e 2,5\% de zinco e começou a ser utilizado em 1961, sendo indicado no controle de doenças de hortaliças e frutíferas em geral, aumentando substancialmente a produção do alimento (RUESS; URECH; EBERLE et al. 1989).

As intoxicações por ditiocarbamatos ocorrem através das vias oral, respiratória e dérmica. Os estudos realizados com animais de laboratório, destacam que os fungicidas ditiocarbamatos provocam ataxia, seguida de debilidade com perda do tono muscular (THORN; LUDWIG, 1962).

c) Herbicidas

Os herbicidas são substâncias que destroem ou inibem o crescimento de ervas daninhas, afetando os constituintes morfológicos ou sistemas bioquímicos das plantas, provocando efeitos que podem levá-las à morte parcial ou total. Assim, os herbicidas favorecem o desenvolvimento das plantações agrícolas (ECOBICHON, 2001).

Segundo Glusczak, Miron, Moraes et. al. (2007), existem diversas formas de classificar os herbicidas, dentre as quais a maioria abordam aspectos relacionados ao comportamento dos produtos ou às suas características.

As principais classificações envolvem os seguintes aspectos: Classificação segundo a seletividade (herbicidas seletivos e herbicidas não seletivos); Classificação segundo a translocação (herbicidas com ação de contato e herbicidas de ação sistêmica); Classificação quanto à época de aplicação (herbicidas aplicados em pré-plantio incorporado, herbicidas aplicados em pré-emergência e herbicidas aplicados em pós-emergência); Classificação quanto à estrutura química e Classificação segundo o mecanismo de ação (GLUSCZAK; MIRON; MORAES et. al., 2007).

Em 1970 foi desenvolvido o herbicida glifosato, que tem se tornado um dos pesticidas mais utilizados no mundo, sendo de característica não seletiva e muito efetivo (DUKE; POWLES, 2002).

Apesar do glifosato ser citado como o mais vendido em todo o mundo e de possuir elevada eficiência na eliminação de ervas daninhas, existem evidências de seus efeitos negativos para a saúde ambiental e humana como, por exemplo, a destruição do habitat de 
REFERENCIAL TEÓRICO

animais e, em seres humanos, como edema pulmonar e dificuldade respiratória (DUKE; POWLES, 2002; BENACHOUR; SÉRALINI, 2008).

O paraquat é um herbicida, de ação rápida e com excelente efeito dentro de células vegetais, que é amplamente utilizado em todo o mundo. No entanto, a solubilidade no solo e a absorção aquosa deste composto podem causar problemas de toxicidade em organismos que não são alvos (GAWARAMMANA; BUCKLEY, 2011).

\subsubsection{Classificação dos agrotóxicos: potencial de periculosidade ambiental e efeitos à saúde}

Como referido anteriormente, de acordo com a atual Legislação, cabe ao Ministério do Meio Ambiente realizar a avaliação ambiental dos agrotóxicos, seus componentes e afins, estabelecendo suas classificações quanto ao potencial de periculosidade ambiental (PPA) (BRASIL, 1996).

A análise dos agrotóxicos para classifica-los quanto ao PPA é baseada em estudos físico-químicos, toxicológicos e ecotoxicológicos. Diante desses testes, os agrotóxicos podem ser distribuídos em classes que variam de I a IV, sendo a Classe I, de maior risco e a IV de menor risco (BRASIL, 1996).

A outra forma de classificar os agrotóxicos leva em consideração os efeitos à saúde, decorrentes da exposição humana a esses agentes, que pode resultar em diferentes classes toxicológicas. Essa classificação obedece a testes ou estudos realizados em laboratório que tentam estabelecer a Dosagem Letal (DL) do agrotóxico em 50\% dos animais utilizados naquela concentração, ou seja, a dose necessária para provocar a morte de 50\% de um lote de animais submetidos ao protocolo experimental (BRASIL, 2003).

Sendo assim, os agrotóxicos também são classificados quanto a DL em quatro classes distintas, a classe I (extremamente tóxico), classe II (altamente tóxicos), classe III (moderadamente tóxicos) e classe IV (pouco tóxicos) (BRASIL, 2003).

A Lei Federal n 7.802 de 11 de julho de 1989 determina que todos os produtos devem possuir, no rótulo, uma faixa colorida indicando a classe toxicológica, cujo propósito básico é distinguir entre os de maior e os de menor periculosidade (BRASIL, 2002). De tal modo os agrotóxicos com a faixa vermelha, são considerados extremamente tóxicos (Classe I); faixa amarela, altamente tóxicos (Classe II); faixa azul, medianamente tóxicos (Classe III) e a faixa verde, são pouco ou muito pouco tóxicos (Classe IV) (Tabela 1) (BRASIL, 2003). 
REFERENCIAL TEÓRICO

Tabela 1. Classificaçäo Toxicológica dos Agrotóxicos

Classe toxicológica

\begin{tabular}{cc}
\hline I & Extremamente tóxico \\
\hline II & Altamente tóxico \\
\hline III & Medianamente tóxico \\
\hline IV & Pouco tóxico
\end{tabular}

Fonte: Dados da Pesquisa (2015).
Cor da faixa

\begin{tabular}{c} 
Vermelho \\
Amarelo \\
\hline Azul \\
\hline Verde \\
\hline
\end{tabular}

Algumas classes de agrotóxicos possuem grande efeito toxicológico tanto para o homem como para o meio ambiente, sendo assim, tornou-se necessário adotar um sistema de descarte e destino final adequado para as embalagens vazias (BRASIL, 2000).

O descarte correto de embalagens vazias de agrotóxicos não é apenas uma atitude consciente, trata-se de obedecer a Lei 9.974/2000 e o Decreto 4.074/2002, que dispõe sobre o tempo máximo de um ano a partir da compra, para o descarte adequado das embalagens de agrotóxicos (BRASIL, 2000).

O descarte incorreto ou fora do prazo determinado em lei pode implicar em multa para o agricultor, o revendedor e até o fabricante do agroquímico. Além da multa, pode ocorrer até a detenção, quando o descaso com o meio ambiente e saúde é muito grave, uma vez que as irregularidades caracterizariam crime ambiental (INPEV; 2007).

Para que a Lei 9.974/2000 possa ser cumprida é necessário seguir alguns passos. Primeiro, esvaziar completamente as embalagens no tanque do pulverizador, depois deve adicionar água limpa em até um quarto do volume do frasco, tampar e agitar por 30 segundos. Esta água também é jogada no tanque do pulverizador. Essa operação tem que ser repetida por três vezes e é chamada de tríplice lavagem (Figura 2) (INPEV; 2007).

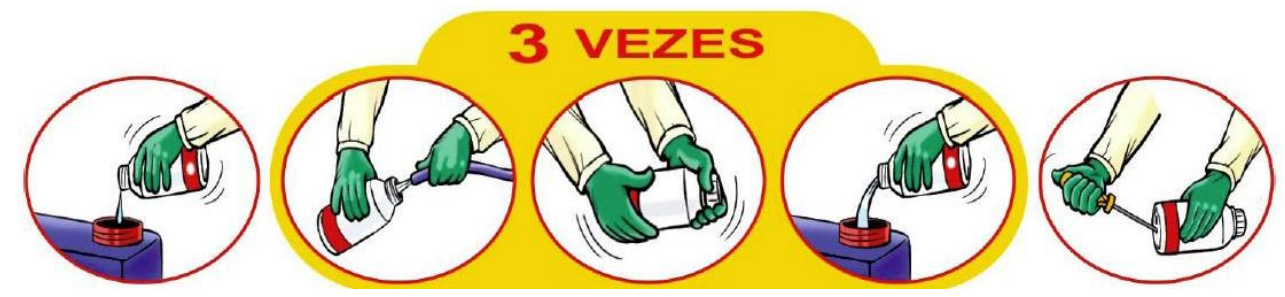

Figura 2.Tríplice lavagem das embalagens dos agrotóxicos

Fonte: Inpev

Após a tríplice lavagem, as embalagens devem ser perfuradas ou cortadas no fundo, com o propósito de evitar a reutilização como recipientes para depósito de outras substâncias. Posteriormente, os frascos lavados e inutilizados devem ser armazenados em um local adequado. A devolução das embalagens pode ser feita pelo próprio agricultor em um posto de recebimento ou na própria loja onde foi adquirido o produto, como também o 
revendedor do produto pode recolher os recipientes. Vale destacar que ao realizar a entrega das embalagens o agricultor recebe um comprovante de devolução, o documento deve ser guardado e apresentado sempre que a fiscalização for até a propriedade (INPEV; 2007).

Todos os recipientes devolvidos são encaminhados para uma central de recebimento, onde as embalagens passam por um novo tratamento e de lá, seguem em blocos compactados e prensados para as indústrias recicladoras (INPEV; 2007).

Seguir a prática do descarte correto é indispensável para cuidar da saúde do ser humano e animais, da terra, do meio ambiente, do país além de contribuir para um mundo melhor.

\subsection{PRINCIPAIS AGROTÓXICOS UTILIZADOS NAS CULTURAS DA REGIÃO DA CHAPADINHA, ZONA RURAL DE BRAZLÂNDIA - DISTRITO FEDERAL}

A Chapadinha localiza-se na Zona Rural de Brazlândia. Possui trabalho agrário intenso, sendo uma região de referência agrícola dentro do DF, diante disso a localidade tornou-se o celeiro de abastecimento do DF e entorno. Vale salientar que a região possui registros de consumo de agrotóxicos, sendo descrito e detalhado no texto abaixo os produtos mais utilizados pelos agricultores da Chapadinha.

\subsubsection{Os fungicidas ditiocarbamatos (DC)}

Os fungicidas da classe dos ditiocarbamatos são largamente utilizados na agricultura, principalmente, em culturas de hortaliças. Os DC apresentam baixa toxicidade para os mamíferos, mas por serem aplicados em altas doses e numa grande variedade de culturas, torna-se necessário controlar os seus níveis residuais nos alimentos. No Brasil os DC são um dos principais produtos utilizados contra fungos, sendo o mancozeb o de maior uso nas culturas de tomates em diferentes regiões do país e no Distrito Federal (THORN; LUDWIG, 1962; BASTOS; GOES; CARDOSO, 2007).

Esses pesticidas têm recebido uma atenção especial devido aos riscos associados ao principal produto de degradação e metabólito de alguns DC, o etilenotiouréia (ETU). Adicionalmente, alimentos tratados com os fungicidas ditiocarbamatos quando processados ou cozidos, podem favorecer as reações de decomposição dos seus resíduos em ETU (GUERRERO; VELANDIA, 2013). 
REFERENCIAL TEÓRICO

São muitos os trabalhos citados na literatura sobre os possíveis efeitos tóxicos da ETU; comprovadamente, a ETU tem a capacidade de induzir tumor na glândula tireóide e no fígado de camundongos (BELPOGGI et al., 2002). A ETU provoca uma diminuição na circulação dos níveis de hormônios tireoidianos e um aumento compensatório da secreção pela hipófise do hormônio estimulante da tireóide (TSH), além de diminuir a capacidade de captação de iodo pela tireóide levando a uma hiperplasia tireoidiana. Os possíveis efeitos agudos são descritos como convulsão, diarréia e insuficiência renal aguda em trabalhadores expostos (BELPOGGI et al., 2002).

\subsubsection{Inseticidas organofosforados (OF)}

Os inseticidas organofosforados são denominados anti-colinesterásicos, pois inibem a ação da enzima do tecido nervoso acetilcolinesterase (AChE) e butirilcolinesterase (BChE). Os estudos de Reiner e Simeon-Rudolf (2006) informa que muitos organosfoforados inibem a butirilcolinesterase (BChE) mais rapidamente que a $\mathrm{AChE}$, sendo assim a inibição da BChE é um indicador mais sensível de absorção para esses compostos.

A butirilcolinesterase é sintetizada no figado e encontrada em outras partes do corpo como: plasma, músculo liso, adipócitos, pâncreas, pele, massa branca do cérebro e coração; enquanto a AChE é encontrada principalmente na membrana dos eritrócitos (SILVA; BORGES JÚNIOR; FIGUEROA-VILLAR et al., 2012). Devido a localização de cada enzima, os sinais e sintomas de intoxicação são associados apenas à inibição da AChE.

A inibição desta enzima (AChE) provoca acúmulo do neurotransmissor, causando hiperestimulação dos receptores do sistema nervoso parasimpático e subsequente bloqueio dos receptores nicotínicos, causando danos ao sistema nervoso central. Sinais de intoxicação aguda por inseticidas organofosforados incluem transtornos da visão, vômitos, ansiedade, confusão mental e hipertensão arterial, efeitos neurológicos diversos e até morte (MARONI et al., 2000).

A exposição crônica a organofosforados também tem sido relacionada com vários tipos de câncer, efeitos teratogênicos, esterilidade, aborto espontâneo e deficiência cognitiva (CIESIELSKI, 1994).

As doses de referências vigentes do Programa de Proteção a Qualidade dos Alimentos dos Estados Unidos (Food Quality Protection Act) foram reduzidas em até 10 vezes, devido ao efeito da exposição crônica de crianças a inseticidas organofosforados. Num conduzido nos Estados Unidos, concluiu-se que mais de um milhão de crianças abaixo de 5 
REFERENCIAL TEÓRICO

anos naquele país estão expostos diariamente a doses não seguras de inseticidas organofosforados através do consumo de alimentos (WILES; DAVIES; CAMPBELL, 1998).

Porém alterações no níveis de colinesterases podem estar relacionadas a outros fatores como leucemia, cirrose, neoplasia, infecções agudas, anemias, uso de drogas entre outros.

\subsubsection{Inseticidas piretroides}

Os piretróides são compostos sintéticos que apresentam estruturas semelhantes à piretrina, substância existente nas flores do Chrysanthemum (Pyrethrun) cinenarialfolium (MAUND; CAMPBELL; GIDDINGS et al., 2012).

As piretrinas possuem ação sob uma vasta variedade de insetos além de uma baixa toxicidade em mamíferos, quando usadas adequadamente. No entanto, as piretrinas naturais tem pouca eficácia para o controle de pragas da agricultura, pois apresentam grande instabilidade à luz solar e ao ar. Visando solucionar esse problema surgiu na década de 70 os piretróides, novo composto sintético que possui maior estabilidade e potencial inseticida além de manter relativamente baixa a toxicidade aguda em mamíferos (HEUDORF; ANGERER, 2001; MAUND; CAMPBELL; GIDDINGS et al., 2012).

Devido a seus benefícios, os piretróides tornaram-se os inseticidas mais utilizados, pois apresentam baixo impacto ambiental, baixa toxicidade em mamíferos e são efetivos contra um largo espectro de insetos. No entanto, o uso inadequado de piretróides tem aumentado os riscos à organismos não-alvos, como pássaros e mamíferos (NASUTI et al., 2003; SPENCER et al., 2001). Ainda, outros estudos demonstraram que os piretróides são muito tóxicos para peixes, abelhas e artrópodes aquáticos, tais como lagostas e camarões (LÓPEZ-ARRABÉ, 2014). Sendo assim, é notório que os piretróides podem atuar em outras espécies expostas acidentalmente durante a aplicação do produto ou ingestão de alimentos contaminados.

Os piretróides, quando usado demasiadamente podem contaminam o ar, a terra e a água provocando efeitos adversos que atingem desde uma bactéria até o homem. Pesquisas comprovam que estes não sofrem bioacumulação através da cadeia alimentar (LÓPEZARRABÉ, 2014). 
REFERENCIAL TEÓRICO

\subsection{OS EFEITOS DOS AGROTÓXICOS}

Os agricultores consideram os agrotóxicos um grande aliado ao incremento da produção, no aumento da qualidade e da quantidade do produto, e na redução de gastos com mão de obra e energia, sendo estes considerados base da agricultura. A fama adquirida pelos agrotóxicos, como poderoso produto que combate às pragas das plantações, contribuiu para que os estudiosos desenvolvessem novos agrotóxicos, como, por exemplo, os organossintéticos, fortalecendo a grande indústria de compostos químicos presentes nos dias de hoje (SILVA; BORGES JÚNIOR; FIGUEROA-VILLAR et al., 2012)

Os benefícios adquiridos pelo uso dos agrotóxicos não estão baseados apenas nos itens destacados acima, mas também são medidos pelo retorno direto no rendimento financeiro das culturas (BOWLES; WEBSTER, 1995). O investimento de um dólar em agrotóxico retorna aproximadamente quatro dólares nas culturas onde são aplicados os produtos, isso vem reforçar a importância econômica desses compostos (MACÁRIO, 2001).

No entanto a diminuição das perdas dos alimentos nem sempre é justificada pelo uso dos agrotóxicos, pois entre 1945 a 1989 nos Estados Unidos, apesar dos produtores terem aumentado o uso dos pesticidas, os danos à agricultura por insetos se elevaram bastante, destacando que nesse mesmo período os agricultores não compreendiam bem os efeitos colaterais da utilização demasiada dos agrotóxicos e o mau uso dos produtos (BOWLES; WEBSTER, 1995).

O próprio uso indiscriminado dos agrotóxicos contribuiu para o aumento das perdas dos alimentos por pragas e doenças, pois os insetos adquiriram resistência a pesticidas, o que leva o agricultor a aumentar a dose, o numero de aplicações de agrotóxicos ou substituir o produto ineficaz por outro. Este problema pode ser considerado hoje um dos mais sérios enfrentados pela agricultura (DÉLANO-FRIER; MARTÍNEZ-GALLARDO; DE LA VEJA et al., 2004).

Além disso, outro problema enfrentado pelo sistema agrário é o alto custo pago para as formulações dos novos agrotóxicos, pois para as suas sínteses, são necessários vários processos que demandam tempo, testes toxicológicos, ensaios de campos, até chegar ao registro final (DÉLANO-FRIER; MARTÍNEZ-GALLARDO; DE LA VEJA et al., 2004).

O contexto do mundo agrário atual visa retardar a resistência desenvolvida pela praga, e para isso é necessário utilizar medidas que controle, visto que o uso abusivo do 
REFERENCIAL TEÓRICO

agrotóxico apresenta sérios efeitos ao homem e o meio ambiente (HOY; HEAD; HALL, 1998).

A utilização do agrotóxico é uma tecnologia única, considerada eficiente, porém acaba contaminando o ambiente, pois, no intuito de combater as pragas da lavoura, independente de atingir o alvo esperado ou não, os agricultores contaminam o seu ambiente de trabalho, tendo em vista que não há outra tecnologia a ser utilizada para alcançar os seres agressores da plantação (PIGNATI; MACHADO; CABRAL, 2007)

Ao atingir o meio ambiente o agrotóxico passa por um complexo caminho para ser degradado ou desativado, “o destino do agrotóxicos no meio ambiente é governado por um processo de retenção (sorção e absorção), de transformação (degradação química e biológica) e de transporte (deriva, volatilização, lixiviação e carreamento superficial), e por interações desses processos" (SPADOTTO, 2006, p. 4).

Sabe-se que os resíduos derivados dos agrotóxicos podem provocar indesejáveis efeitos no sistema ecológico, visto que os compostos químicos são capazes de alterar a dinâmica biológica, tendo como consequência mudanças na função ecológica do ecossistema, culminando numa degradação ambiental contaminando o solo e os sistemas hídricos (SPADOTTO et al., 2010).

O solo tem a capacidade de absorver grandes quantidades de contaminantes sem sofrer grandes transformações, no entanto, com o passar do tempo e o uso abusivo de compostos químicos poluentes, estas transformações tornam-se quase sempre irreversíveis, causando danos de difícil recuperação (SISINNO, 2003).

Além disso, a poluição por agrotóxicos provoca erosão, pois acabam destruindo ervas daninhas, importantes na fixação do solo; e aumento da desertificação (aceleração da evaporação), como é o caso da desertificação presente em algumas áreas do Rio Grande do Sul (ALTIERI, 2009)

Até o fim da década de 70 acreditava-se na degradação dos agrotóxicos em partículas inofensivas, as quais seriam incapazes de poluírem o sistema hídrico, era efetiva, porém estudos posteriores comprovaram, através das tecnologias analíticas, que o uso intensivo de agrotóxicos contaminam os sistemas hídricos. Com isso, os cientistas descobriram que o poder de contaminação do agrotóxico não se restringe apenas ao solo, afetando também os sistemas hídricos (GILLIOM et al., 1999).

A fauna e a flora também são amplamente afetadas com o uso indiscriminado desses insumos químicos. Vale informar que as terras carregadas pelas águas das chuvas 
REFERENCIAL TEÓRICO

levam para os rios, lagoas e barragens, os resíduos de agrotóxicos, comprometendo a fauna e a flora aquática, podendo causar a extinção de animais (BERTI; DÜSMAN; SOARES, 2009).

Juntamente com a introdução dos produtos químicos no controle de pragas e doenças que afetam a produção agrícola, surgiu a preocupação com a presença de agrotóxicos nos alimentos. Mesmo sendo uma polêmica antiga, foi somente nos anos mais recentes que se conseguiu a avaliação da qualidade dos alimentos que chegam à mesa da população. Essa notícia proporcionou um alívio para o consumidor, pois é impossível diferenciar o alimento com nível de agrotóxicos irregulares na prateleira do supermercado sem antes analisa-los nos laboratórios adequados (SOUZA, 2006).

Visando apresentar os níveis adequados de agrotóxicos nos alimentos, a Agência Nacional de Vigilância Sanitária (Anvisa) criou o Programa de Análise de Resíduos de Agrotóxicos em Alimentos (PARA), onde, nos últimos anos tem monitorado diversas culturas presentes na mesa dos brasileiros, e como resultados observou-se o uso de produtos não autorizados para determinada cultura e resíduos de agrotóxicos encontrados acima dos níveis permitidos pela legislação (SOUZA, 2006; VINHA ET AL., 2013).

A partir dos resultados obtidos do PARA os produtores e autoridades da área agrícola estão mais atentos os níveis de agrotóxicos presentes em alimentos. Mesmo assim, ainda são grandes as irregularidades encontradas no uso de agrotóxico (VINHA et al., 2013).

A Anvisa divulgou o relatório final do Programa de Analise de Resíduos de Agrotóxicos em Alimentos para o ano de 2012. Dentre as amostras coletadas naquele ano 1,9\% apresentaram quantidade de agrotóxico acima do Limite Máximo de Resíduos. Os alimentos monitorados pela Anvisa são a abobrinha, alface, feijão, fubá de milho, tomate e uva, cujos resultados ainda não haviam sido divulgados (BRASIL, 2014).

Em 2010, dentre os alimentos analisados pelo PARA, o pimentão, o morango e pepino foram os alimentos com o maior número de amostras contaminadas por agrotóxico. De acordo com os resultados, mais de $90 \%$ das amostras de pimentão analisadas apresentaram problemas, já o morango e o pepino apresentaram $63 \%$ e 58\%, respectivamente, de amostras irregulares (BRASIL, 2011).

Como referido nos parágrafos anteriores, os agrotóxicos foram encontrados, seja em níveis acima dos limites máximos permitidos ou em culturas para as quais não são autorizados, em muitos dos alimentos analisados pelo programa, o que pode representar riscos à saúde das populações que consomem tais alimentos (MIRANDA; BORGES, 2014). 
São bastante conhecidos e difundidos os benefícios imediatos que advêm da aplicação de pesticidas sobre a produtividade agrícola. No entanto, existe uma inquietação com relação ao efeito prejudicial que estes produtos podem ocasionar sobre a saúde humana e no ecossistema em geral. No ano de 2003 foram notificados no Brasil aproximadamente 8000 casos de intoxicações por agrotóxico (BOCHNER, 2007).

Sabe-se que a produção e consumo de alimentos dentro da agricultura ocupam vastos territórios e envolvem diferentes grupos populacionais, com isso, os agrotóxicos utilizados podem tornar-se problemas de saúde pública (MIRANDA; BORGES, 2014). Dentre todos os seres humanos expostos ao produto químico, o que merece mais atenção é o trabalhador rural. No Brasil, os trabalhadores do campo convivem cada vez mais com os riscos do uso de agrotóxicos, sendo um grupo populacional reconhecidamente mais vulnerável aos efeitos danosos à saúde, principalmente pela sua exposição aguda (BOCHNER, 2007).

A atividade agrícola pode ser considerada uma perigosas fonte de trabalhao, se observado o alto risco ocupacional que os trabalhadores estão expostos aos pesticidas. Como exemplo pode-se citar as intoxicações agudas, doenças crônicas, problemas reprodutivos, entre outros (VINHA et al., 2013).

Os estudos de Pingali (2012) fazem a correlação entre problemas de saúde e exposição ao composto químico agrícola. Os autores descobriram que duas aplicações de inseticidas por safra aumentou a probabilidade de problemas nos olhos em $22 \%$, quando se refere aos problemas de pele o problema aumentou em $30 \%$ para aqueles que faziam uma aplicação por safra, e em $50 \%$ para os que faziam duas aplicações. Já a incidência de problemas gastrointestinais mostrou que aumentos de uma dose de herbicida para duas ou três, elevaram a probabilidade de anomalias gastrointestinais em $85 \%$ e $167 \%$, respectivamente.

Outro estudo realizado em oito municípios do Mato Grosso encontrou 100\% a mais de ocorrência de malformação congênita entre as crianças de mães expostas aos agrotóxicos durante o período periconcepcional em relação às demais (OLIVEIRA et.al., 2014).

Um estudo para avaliar a associação entre contato com agrotóxicos e prevalência de doenças crônicas em população rural do Sul do Brasil constatou que indivíduos em contato com agrotóxicos apresentaram 2,5 vezes mais chances de relatar doenças neurológicas e 2 
REFERENCIAL TEÓRICO

vezes mais chances de relatarem síndromes dolorosas do que os que não estão em contato com os produtos (SOUZA et al., 2011).

Em Nova Friburgo, Rio de Janeiro, também destaca a possibilidade de associação entre exposição a agrotóxicos e doenças crônicas não-transmissíveis, tais como câncer, endocrinopatias, doenças neurológicas e outras. Nesse mesmo estudo foi verificado respostas alteradas ao exame neurológico periférico do sistema motor e sensitivo em uma amostra de 102 pequenos agricultores, de ambos os sexos, sugerindo neuropatia tóxica, com provável degeneração axonal (ARAÚJO et al., 2007).

\subsubsection{Exposição a agrotóxicos: Processo de produção rural e os impactos na saúde do trabalhador}

Os estudos dos impactos negativos à saúde humana, advindos da relação entre trabalho, saúde e ambiente são consequências de uma evolução do conhecimento em diversos campos ao longo do tempo. O tema é de natureza global e interdisciplinar e inesgotável, se apresentando como desafio a ser interpretado.

Levando em consideração essa temática, os estudos entre a relação dos fatores de risco associados ao uso de agrotóxicos e saúde do trabalhador rural, são da grande importância para a saúde pública, uma vez que, a aplicação indiscriminada desses produtos vem afetando tanto a saúde humana quanto os ecossistemas naturais.

O trabalho agrícola difere dos trabalhos existentes em uma unidade de produção fabril, onde o ambiente é em geral fechado e assim várias condições podem ser controladas (como ventilação, temperatura, iluminação). Já na ambiente de trabalho do agricultor, a maioria das atividades acontece a céu aberto, impossibilitando o controle direto deste e consequentemente dos fatores que podem trazer prejuízo à saúde do trabalhador (GARCIA, 2005).

Fato que merece ser destacado no trabalho rural brasileiro é a participação de crianças e adolescentes nas atividades de trabalho agropecuário. O Censo Agropecuário (2007) traz a informação de que 18,6\% da população rural ocupada são trabalhadores menores de 14 anos de idade que atua no setor.

Peses, Rosemberg e Lucca (2005) informa que a agricultura de pequeno porte e predominantemente familiar, desenvolve nas relações sociais do campo uma ajuda mútua entre adultos e crianças, expondo estes jovens a uma condição de riscos de contaminação. 
A extensiva utilização dos agrotóxicos vem representando um problema de saúde pública nos países em desenvolvimento, especialmente aqueles que possuem economia baseada em agronegócio, como é o caso do Brasil (ARAUJO et al., 2000).

Cada dia cresce mais o número de pessoas com agravos à saúde decorrentes da utilização de agrotóxicos, sendo os trabalhadores rurais os mais acometidos pelos problemas de saúde (SOARES et al., 2003). A lista de doenças é enorme, a exemplo temos a depressão, mal formações congênitas, infertilidade, alguns tipos de câncer como leucemia e tumores de cérebro, transtornos da imunidade, alterações na qualidade dos espermatozoides, entre outros. As patologias citadas são consequências das intoxicações, seja aguda, subaguda ou crônica, causadas pelo composto químico (MOSTAFALOU; MOHAMMAD , 2013).

$\mathrm{Na}$ intoxicação aguda os sintomas surgem rapidamente, isto é, logo após a exposição excessiva em um curto período a produtos extremamente ou altamente tóxicos, o homem sente sinais clínicos específicos da intoxicação. Dependendo da quantidade de agrotóxico absorvido, o envenenamento agudo pode ocorrer de forma leve, moderada ou grave, com sinais e sintomas nítidos e objetivos, podendo evoluir para o óbito (BRASIL, 1997).

A intoxicação subaguda possui sintomas subjetivos e indefinidos, tais como malestar, dor de estômago, dor de cabeça, fraqueza e sonolência, pois a exposição humana moderada ou leve a produtos altamente ou medianamente tóxicos causam o aparecimento mais lento dos sintomas (BRASIL, 1997; ROSS et al., 2001).

Já na intoxicação crônica, que é a pequena ou moderada exposição humana a múltiplos produtos tóxicos ao longo de toda a vida, os sintomas aparecem após meses ou mesmo anos depois do contato, podendo causar danos irreversíveis, como paralisias e neoplasias (BRASIL, 1997).

Apesar das intoxicações agudas serem mais perceptíveis e mais rapidamente associadas à exposição a substâncias químicas como os agrotóxicos, as intoxicações crônicas também ocorrem e merecem atenção especial, além disso, a reversibilidade do quadro clínico, em geral é muito difícil (SOARES et al., 2003).

Os efeitos tóxicos são evidenciados quando o indivíduo fica exposto uma ou várias vezes ao produto, dependendo da toxidade do composto químico. O padrão de exposição (dose, frequiência e duração), absorção, metabolismo, cinética de distribuição e eliminação, toxicodinâmica e toxicinética estão relacionados com o efeito tóxico do produto químico (KEIM; ALAVANJA, 2001). 
Algumas atividades dos agricultores, como a estocar pesticidas no domicílio ou a lavagens de roupas dos familiares juntamente com roupas contaminadas pela aplicação dos agrotóxicos estão diretamente relacionadas às ocorrências de problemas, onde o contato com os agrotóxicos mais estão presentes (ROSS et al., 2001). É importante considerar que as causas descritas nem sempre ocorrem devido à negligência do trabalhador. A questão é muito mais abrangente e envolve uma série de outros fatores.

Segundo Mage e colaboradore (2000) há três fatores na agricultura onde os trabalhadores estão altamente expostos. Estes são a inexperiência do aplicador; eventos inesperado/aleatório, como uma ruptura de mangueira; e quando o trabalhador não segue as recomendações que acompanham as embalagens, isto é as recomendações do fabricante, além da negligência com o uso correto dos Equipamentos de Proteção Individuais.

Vale destacar que estes eventos podem ser causados tanto pelos agrotóxicos mais tóxicos, como pelos compostos que possuem menor caráter tóxico, que dependendo da frequência de exposição podem desenvolver alterações da capacidade psíquica trabalhador (ROSS et al., 2001).

Além de complicações na saúde, o composto químico causa impacto no meio ambiente. Sendo assim, buscou-se métodos para reduzir os efeitos negativos do produto ao meio ambiente tais como indução de resistência das plantas contra às pragas e utilização de produtos químicos naturais e o controle biológico (PICANÇO et al., 2000).

De maneira geral, para diminuir risco ocupacional e ambiental e os casos de acidentes e tentativas de suicídio, é necessário reduzir a disponibilidade e o uso de pesticidas (GUNNELL et al., 2007). Atualmente os meios de vigilância utilizados são insuficientes para caracterizar os problemas relacionados ao uso de agrotóxicos e ás doenças decorrentes desse manejo. Assim, é necessário limitar a exposição do ser humano aos agrotóxicos assim como incentivar a utilização de produtos menos tóxicos (CALLAHAN et. al., 2014).

Embora as pesquisas sobre os impactos do uso dos agrotóxicos na saúde e meio ambiente tenham crescido nos últimos anos, ainda é insuficiente para se conhecer a dimensão dos seus efeitos negativos ao ecossistema. Um dos problemas que contribui para isso é a falta de informações sobre o consumo de agrotóxicos e a insuficiência de dados sobre intoxicações por esses produtos (FARIA et al., 2007).

\subsection{PERCEPÇÃO DE RISCOS À SAÚDE NO USO DE AGROTÓXICOS}


Antes de adentar na temática sobre a percepção de risco à saúde é necessário comentar sobre a saúde. Alguns trabalhos já têm evidenciado a diferença entre conceitos de saúde populares e acadêmicos.

Levando em consideração a ótica da Organização Mundial da Saúde, a saúde é entendida como o estado do mais completo bem-estar físico, mental e social e não apenas a ausência de enfermidade (WHO, 1946).

Marc Lalonde complementa o conceito quando afirma que saúde deve expressar o direito a uma vida plena, sem privações. Segundo o autor, o conceito de saúde abrange a biologia humana, que compreende a herança genética e os processos biológicos inerentes à vida, incluindo os fatores de envelhecimento; o meio ambiente, que inclui o solo, a água, o ar, a moradia, o local de trabalho; o estilo de vida, do qual resultam decisões que afetam a saúde: fumar ou deixar de fumar, beber ou não, praticar ou não exercícios; a organização da assistência à saúde (VERDI; CAPONI, 2005).

O conceito popular de saúde é definido como fruto do viver cotidiano, no qual é exposto aquilo que sentem, percebem, faz parte do seu viver, estando vinculado com suas experiências de vida, seus valores e visão de mundo, ficando, por esta razão, vinculado à sua cultura. Contudo, a saúde é vista por ambos, como um direito de todos e dever do Estado, que deve garantido a redução do risco de doença e de outros agravos.

Garcia (2005) define risco como "a probabilidade de que uma substância produza um dano em condições específicas de uso". Esse conceito guarda relação com a utilização de substâncias químicas. Para o autor o risco associado a uma substância tem relação direta com dois fatores: a capacidade de produzir danos a saúde e ao meio ambiente, ou seja, a toxicidade e as condições que determinam a exposição a essa mesma substância.

Os seres humanos criaram o conceito de risco para ajudá-los a entender os perigos e a conviver com os mesmos e as incertezas da vida (SLOVIC, 1999). O perigo é entendido como uma fonte potencial de dano e o risco é um valor estimado que leva em consideração a probabilidade de ocorrência de um dano e a gravidade de tal dano.

Apesar das análises de riscos auxiliarem a prática epidemiológica, especialmente para estudar fatores que condicionam a ocorrência e evolução de doenças crônicas, essa abordagem nos dias de hoje tem aplicação ampla. Os processos de saúde e doença de uma população obedecem a múltiplas causas e estas têm origem tanto das condições culturais, sociais e econômicas quanto das características físicas e biológicas dos indivíduos e seu ambiente (MEYER; RESENDE; ABREU,2007). 
A saúde, portanto, deve ser entendida em sua dimensão global, levando em consideração a pluricausalidade, onde os elementos "bio-sócio-ambientais e produtivos relacionam-se de maneira "independente e interdefinível” tendo um caráter complexo (AUGUSTO et al., 2002).

Para Soares, Almeida e Moro (2003) a percepção de risco é definida quando o indivíduo possui a habilidade de interpretar uma situação de potencial dano à saúde ou à vida, baseada em experiências anteriores e sua extrapolação para um momento futuro, que varia de uma vaga opinião a uma firme convicção.

Na problemática da contaminação rural por agrotóxicos no Brasil, Peres (2005) afirma que muitos estudos acerca da contaminação rural por agrotóxicos no Brasil não leva em consideração a dimensão do risco representado pela exposição a estes produtos, focalizando suas investigações nas análises técnicas, baseadas nos conhecimentos da toxicologia.

$\mathrm{O}$ autor ainda observa que os produtores rurais enxergam a prática do uso do agrotóxico como atividade voluntária e familiar, pois é comum ao seu cotidiano. Esta familiaridade contribui para que eles tendam a atribuir níveis relativamente baixos de risco ao uso desses agentes.

\subsubsection{Medidas de controle de risco}

A saúde do trabalhador rural é um assunto bastante discutido entre os profissionais de saúde e de extensão rural, visto que a morbidade entre essa classe trabalhadora é perceptível e merece atenção (CALLAHAN, 2014).

Quando se refere aos acidentes de trabalho no meio rural decorrente do uso e manejo dos agrotóxicos, estudos apresentam a negligência como principal fator desencadeante do processo de intoxicação e suas consequências (GREGOLIS; PINTO; PERES, 2012).

O preparar da calda do pesticida possui alto risco de intoxicação, pois é um evento que deixa o trabalhador bem exposto ao produto químico. Nesse processo o agricultor manipula a embalagem, rompe o lacre, retira a tampa e o lacre do bocal da embalagem, dosa a formulação e recoloca a tampa (GREGOLIS; PINTO; PERES, 2012). Essa etapa é mais perigosa do que a própria aplicação em campo, pois nesse segundo momento o composto é diluído em água (LEVESQUE; ARIF; SHEN, 2010). 
REFERENCIAL TEÓRICO

A possibilidade de intoxicação nas situações de contato com o agrotóxico atribuiu às condições de trabalho classificações quanto à segurança. As condições de trabalho seguras são representadas pela probabilidade de não ocorrer lesões e intoxicações com agrotóxicos devido a exposição em condições específicas de trabalho (RIQUINHO; HENNINGTON, 2014).

O meio ambiente onde o trabalhador se encontra e os materiais utilizados para desenvolver a atividade laboral compõe a condição de trabalho. Esta situação deve ser avaliada para selecionar as medidas de segurança mais adequadas e eficientes, visando reduzir os riscos de intoxicações ocupacionais a níveis aceitáveis (RIQUINHO; HENNINGTON, 2014).

A Anvisa agrupa as medidas de segurança em preventivas e de proteção, que podem ser agrupadas em individuais e coletivas. Dentre as medidas de segurança coletiva estão àquelas relacionadas aos ambientes de trabalho para controlar a exposição dos trabalhadores (BRASIL, 2006).

Estudos apontam dificuldades para desenvolver projetos de medidas de engenharia para o controle direto sobre o local de trabalho dos agricultores, o que trona um problema para o tratamento técnico no que se refere aos aspectos de segurança no ambiente rural, visto que normalmente ambientes de trabalho inadequados e devem ser evitados e controlados (MACHADO NETO; COSTA; OLIVEIRA, 2007).

Sob essas condições as medidas individuais, como as práticas de trabalho e o uso de equipamentos de proteção individual, se destacam. Os Equipamentos de Proteção Individual (EPI) são definidos pela Norma Regulamentadora número 6, aprovada pela Portaria no 3.214/78, do Ministério do Trabalho. São as vestimentas e equipamentos individuais, destinados a proteger os trabalhadores contra diversos riscos (BRASIL, 1978).

No Brasil é comum encontrar EPI's inadequado às condições ergonômicas e ambientais, o que favorece a negligência quanto a utilização dos EPIs obrigatórios pelos trabalhadores no momento da manipulação e da aplicação de agrotóxicos. Os agricultores atribuem o fato do desconforto e incômodo, devido a sua inadequação, para justificar a prática incorreta (COLPO; NUNES; ARAÚJO, 2013).

Os EPI's devem possuir um certificado de aprovação, expedido pelo Ministério do Trabalho, pois através deste certificado é possível identificar que o equipamento passou por um processo de registro junto ao órgão controlador. De uma maneira geral um EPI adequado 
REFERENCIAL TEÓRICO

para segurança do trabalhador deve ser composto de luvas e botas, máscara, viseira, touca árabe, avental, calça e camisa (MEIRELLES; GARRIGOU; BALDI, 2007).

O texto de Bonato (2007) informa que várias indústrias realizam campanhas de sensibilização em relação ao uso correto dos agrotóxicos, quanto à importância da utilização dos equipamentos de proteção (EPI) e quanto ao destino das embalagens vazias dos agrotóxicos, visando proteção da saúde e preservação do meio ambiente.

A Empresa de Assistência Técnica e Extensão Rural do Distrito Federal (Emater/DF) realiza um trabalho que promove o desenvolvimento rural e sustentável e a segurança alimentar, por meio de Assistência Técnica e Extensão Rural de excelência, através de ações educativas quanto ao uso correto de agrotóxicos, tendo em vista melhorar a qualidade de vida de pessoas vulneráveis ao agrotóxico (MATOS, 2010).

Além disso, a Emater-DF presta de assistência técnica aos produtores rurais visando assegurar produção e renda das culturas e promove apoio gerencial aos produtores rurais. 
METODOLOGIA

\subsection{TIPO DE PESQUISA}

Tratou-se de um estudo exploratório-descritivo de natureza transversal, com abordagem mista, isto é, na perspectiva qualitativa e quantitativa. Segundo Gil (2005), o estudo descritivo permite ao pesquisador observar, descrever e classificar um determinado fenômeno, esclarecendo sua predominância e características. O estrudo transversal é caracteriazado pela coleta de uma ou mais variáveis em um mesmo período (GUJARATI,2008).

Sobre a pesquisa qualitativa Minayo (2009) enfoca ainda que esta se trata de uma atividade da ciência, a qual visa a construção da realidade, trabalhando com o universo de crenças, valores, significados e outros construtos profundos das relações que não podem ser reduzidos à operacionalização de variáveis. Segundo o mesmo autor, este tipo de pesquisa busca elucidar questionamentos específicos por meio da escuta dos sujeitos, para que sequencialmente possa ser possível a interpretação dos fenômenos cujos significados estão vinculados a um dado contexto.

Dessa maneira, a opção por este tipo de estudo é justificável devido o objeto centrar-se na aquisição de pensamentos coletivos, onde a apreensão dos mesmos torna-se o foco da investigação.

A pesquisa quantitativa considera que tudo pode ser quantificável, o que significa traduzir em números opiniões e informações para classificá-las e analisá-las. Requer o uso de recursos e de técnicas estatísticas (percentagem, coeficiente de correlação, etc.) (KÖCHE, 1997).

\subsection{PARTICIPANTES, LOCAL E PERÍODO DA PESQUISA}

A pesquisa foi realizada na região da Chapadinha, Zona Rural de Brazlândia/DF. Trata-se de uma região de referência agrícola dentro do Distrito Federal, onde o trabalho agrário é intenso, sendo celeiro de abastecimento do entorno. Vale salientar que há registros na região de frequente uso de agrotóxicos, o que instigou à busca de mais informações e questionamentos no que se refere ao manejo do composto químico pelos agricultores e seus efeitos na saúde da população da área estudada ${ }^{7}$.

De acordo com a perspectiva qualitativa, participaram da pesquisa 10 agricultores familiares que têm contato direto ou indireto com os agrotóxicos, sendo esta uma condição 
elencada como critério de inclusão estabelecido para uma melhor homogeneização do grupo amostral. Foram excluídos, aqueles participantes que se recusaram a assinar, previamente, o Termo de Consentimento Livre e Esclarecido (APÊNDICE 1) e não concordaram em participar da pesquisa.

A determinação do número de participantes foi relacionada com o critério de saturação de dados, a qual ocorre quando a coleta de dados para de produzir novas informações ficam redundantes.

Vale salientar que as entrevistas foram realizadas entre os meses de fevereiro e março de 2015, nos turnos matutino (08:00 às 12:00h) e vespertino (13:00 às 17:00h) conforme a disponibilidade do agricultor. Ressalta-se também que foi solicitada, aos participantes do estudo, a autorização para gravar as entrevistas, que posteriormente foram transcritas na íntegra e analisadas.

Para melhor fundamentar a estudo sobre os efeitos do agrotóxico na saúde do trabalhador rural de Brazlândia, a pesquisa preocupou-se também, em contemplar ademais dos dados subjetivos colhidos nas entrevistas, o estudo das análises de sangue dos trabalhadores da região para determinação da Butirilcolinesterase.

Sendo assim, desde a perspectiva quantitativa, trabalhou-se com os dados secundários obtidos de duas campanhas para coletas de sangue dos agricultores, as quais foram realizadas pelo Núcleo de Saúde Rural (NSR) da Secretaria de Saúde do Distrito Federal em parceria com o Laboratório Central de Saúde Pública (LACEN-DF) e a pesquisadora. Todo processo teve o apoio logístico da Empresa de Assistência Técnica e Extensão Rural do Distrito Federal - Emater/DF.

Visando conhecer melhor sobre a saúde dos trabalhadores da região, em outubro de 2013 foi coletado 27 amostras sanguíneas dos agricultores; e em abril de 2014 um segundo evento foi efetivado, do qual participaram mais 39 pessoas, seguindo os mesmos critérios dos exames anteriores. É importante ressaltar que 2 agricultores participaram dos dois momentos de coletas sanguínea. Sendo assim, participaram da pesquisa quantitativa 66 trabalhadores rurais. 
METODOLOGIA

\subsection{INSTRUMENTO PARA A COLETA DE DADOS E PROCEDIMENTOS DA PESQUISA}

Os dados da pesquisa qualitativa foram coletados mediante roteiro de entrevista semi-estruturada, a qual foi gravada e realizada junto aos agricultores familiares. O instrumento roteiro de coleta (APÊNDICE 2) foi composto por questões abertas e fechadas, dividido em duas seções. A primeira, referente à identificação e caracterização sóciodemográfica dos informantes e a segunda, composta por questões subjetivas, cuja finalidade foi abordagem da temática central do estudo. Assim, se procederam os seguintes questionamentos: - O que é saúde pra você?; - O que você acha do uso de agrotóxicos nas lavouras?; - Você utiliza agrotóxico em sua lavoura?; - O que você pensa sobre o uso do agrotóxico nas plantações onde trabalha e a relação com sua saúde?; - Na sua rotina de trabalho, qual a etapa do processo de produção que usa o agrotóxico causa maior risco para saúde?; - Alguma vez foi hospitalizado(a) ou procurou ajuda médica? E devido ao contato com o agrotóxico?; - Qual a sua opinião sobre o uso do Equipamento de Proteção Individual (EPI) para proteger a saúde do agricultor?; - Quais os EPI's que você utiliza?; - Na sua opinião, quais os cuidados realizados pelos trabalhadores para proteger a tanto a sua saúde como a da comunidade?

As perguntas norteadoras tiveram por objetivo buscar respostas sem direcionar os resultados, deixando o entrevistado à vontade para exteriorizar suas experiências e sentimentos.

Para registro da entrevista foi utilizado um aparelho de MP3 player, o qual garantiu maior fidelidade e veracidade das informações coletadas. Após essa etapa, o material foi transcrito na íntegra, sendo posteriormente analisado a luz da literatura pertinente.

Do ponto de vista quantitativo, as amostras de sangue foram coletadas com vacuntainer heparinizados através de punção venosa, em sala adequada e adaptada na região da Chapadinha com a participação de 4 técnicos especializados em coleta, armazenamento e transporte de sangue, com o intuito de preservar a qualidade da amostra. Considerou-se o jejum com pré-requisito para coleta, sendo as amostras colhidas entre 9 e 10 horas da manhã.

Após a coleta os tubos foram centrifugados, sendo que os elementos figurados foram separados do plasma. As amostras de plasma foram estocadas a $-20^{\circ} \mathrm{C}$ até o momento de determinação da atividade enzimática da butirilcolinesterase, que utilizou o kit comercial da Wierner. 
METODOLOGIA

\subsection{ANÁLISE DOS DADOS}

Para o tratamento qualitativo dos dados utilizou-se a técnica de análise de conteúdo na modalidade temática sob a ótica de Minayo (2009), a qual explicita em etapas: a) Entrevista transcrita na íntegra e realização de leitura flutuante do material, com vistas à apreensão do todo. As entrevistas foram numeradas de forma crescente de acordo com a ordem de realização da mesma. Sendo transcritas de forma legítima no Microsoft Office Word para melhor interpretação e categorização; b) Determinação das unidades de análise, registro ou unidades de significados ou temas. Segundo Oliveira (2008, p. 572), "as unidades de registro podem ser: palavras, frases, parágrafos, temas objeto, personagem, acontecimento e documento"; c) Processo de categorização e sub-categorização, caracterizada como grandes enunciados que abarcam um número variável de temas, segundo seu grau de proximidade, e que podem exprimir significados e elaborações importantes que atendam aos objetivos de estudo; e d) Análise propriamente dita do material empírico produzido, chegando à construção do núcleos de sentido: 1) "O trabalhador rural e o contato com agrotóxicos"; 2) "Saúde do agricultor". Para possibilitar uma discussão mais aprofundada acerca dos referidos núcleos, mediante a técnica de Análise de Conteúdo na Modalidade Temática, desta emergiram quatro categorias, sendo duas provenientes de cada núcleo permitindo assim um melhor direcionamento do estudo, são elas: "As percepções dos agricultores sobre a exposição ao agrotóxico"; "Cuidados individuais e coletivos adotados pelos trabalhadores"; "Concepção dos agricultores sobre a saúde"; "Sinais e sintomas relatados pelos trabalhadores".

$\mathrm{Na}$ apresentação dos resultados utilizou-se as letras "TR" para identificar o Trabalhador Rural entrevistado, seguido de uma sub-ordenação dos números 1, 2, 3, 4, 5, 6, 7, 8 que representa a sequencia de realização das entrevistas.

Para a analisar a butiriltiocolina, é necessário entender o processo fisiológico. Sabese que a butiriltiocolina é hidrolisada pela $\mathrm{BChE}$, produzindo ácido carboxílico e tiocolina, a qual reage com o reagente de Ellman (ácido ditionitrobenzóico) para formar uma coloração amarela que é medida espectrofotometricamente a $450 \mathrm{~nm}$. Sendo assim, a taxa de formação da cor é proporcional à quantidade de BChE (REINER; SIMEON-RUDOLF, 2006). Para elaborar o banco de dados, utilizou-se os resultados obtidos das amostras de sangues, que posteriormente foram tabelados pelo Software Excel 2007 e plotados em gráfico para melhor visualização. 
METODOLOGIA

\subsection{ASPECTOS ÉTICOS DA PESQUISA}

Por se tratar de uma investigação envolvendo seres humanos, o projeto foi submetido e aprovado pelo Comitê de Ética em Pesquisa com Seres Humanos da Faculdade de Ciências da Saúde da UnB sob o Parecer número 943.423 e CAAE 36742014.3.0000.0030, como preconiza a Resolução 466/2012 do Conselho Nacional de Saúde (ANEXO A). Os participantes assinaram o Termo de Consentimento Livre e Esclarecido, em duas vias, ficando com uma cópia e a outra sob posse do pesquisador responsável. Com o propósito de atender princípios éticos, os sujeitos envolvidos na pesquisa foram informados e esclarecidos sobre os seus objetivos.

O procedimento ocorreu em dois momentos: o primeiro consistiu de um contato prévio e individualizado com cada agricultor, onde foram explanados os objetivos da pesquisa, a importância de sua participação e a apresentação de todos os itens contemplados no Termo de Consentimento Livre e Esclarecido (TCLE) o qual foi assinado pelo trabalhador rural, sendo inclusive referida a livre opção de aceitar participar da pesquisa sem qualquer prejuízo pessoal, podendo inclusive o participante retirar-se antes, durante ou depois da finalização de coleta de dados.

Sequencialmente, em um segundo momento, após a aceitação de inclusão na pesquisa pelos participantes a entrevista foi iniciada, sendo assegurado o anonimato de sua identidade como explicitado no termo de Consentimento livre e esclarecido. Salientamos ainda que ao participante foi entregue uma cópia do Termo de Consentimento Livre e Esclarecido devidamente assinada pelos pesquisadores envolvidos na referida pesquisa.

As pesquisadoras cumpriram fielmente as diretrizes regulamentadoras emanadas na Resolução 466/2012 do Conselho Nacional de Saúde/MS e suas complementares, assinando também um termo de compromisso, visando assegurar os direitos e deveres que dizem respeito à comunidade científica, aos sujeitos da pesquisa e ao Estado.

\subsection{FINANCIAMENTO DA PESQUISA}

Os itens necessários à execução da pesquisa foram todos da responsabilidade dos pesquisadores envolvidos. Demonstrando-se, portanto, a nulidade de ônus, de qualquer natureza para o participante desse estudo, uma vez que todos os elementos necessários para a avaliação e tratamento classificaram-se como de fácil aquisição e baixo custo. 


\section{RESULTADOS E DISCUSSÃO}


RESULTADOS E DISCUSSÃO

\subsection{CARACTERIZAÇÃO DOS SUJEITOS DA PESQUISA}

Dados socioeconômicos revelaram que os agricultores familiares e moradores da Chapadinha, Zona Rural de Brazlândia-DF participantes do estudo possuem faixa etária variável entre 26 e 63 anos, sendo sete do sexo masculino e três do sexo feminino. A maioria dos participantes (80\%) é casada, apresentando renda familiar entre um e quatro salários mínimos e trabalham na agricultura há mais de oito anos. Dentre os dez participantes, sete são não fumantes e todos utilizam agrotóxicos na sua plantação. Em relação à escolaridade, oito possuem o ensino fundamental incompleto e dois, ensino médio completo (Tabela 2).

\begin{tabular}{ccccc}
\hline \multicolumn{4}{c}{ Tabela 2: Dados sóciodemográficos dos entrevistados. Brazlândia. Brasil, 2012. } \\
\hline Trabalhador Rural & Idade & Estado civil & Escolaridade & Sexo \\
\hline TR1 & 55 & Casado(a) & Ens. fund. incompleto & Masculino \\
\hline TR2 & 30 & Solteiro(a) & Ens. fund. incompleto & Masculino \\
\hline TR3 & 26 & Casado(a) & Ens. fund. incompleto & Feminino \\
\hline TR4 & 28 & Solteiro(a) & Ens. fund. incompleto & Masculino \\
\hline TR5 & 55 & Casado(a) & Ens. fund. Incompleto & Feminino \\
\hline TR6 & 37 & Casado(a) & Ensino médio completo & Masculino \\
\hline TR7 & 42 & Casado(a) & Ensino médio completo & Masculino \\
\hline TR8 & 40 & Casado(a) & Ens. fund. incompleto & Masculino \\
\hline TR9 & 35 & Casado(a) & Ens. fund. Incompleto & Feminino \\
\hline TR10 & 63 & Casado(a) & Ens. fund. incompleto & Masculino \\
\hline
\end{tabular}

Fonte: Dados da Pesquisa (2015).

No decorrer das entrevistas, os agricultores relataram sobre os agrotóxicos que utilizavam em sua plantação, dentre os 12 produtos mais citados, metade classifica-se entre altamente e extremamente tóxico para a saúde humana de acordo com a Tabela 3. Sendo assim, os agricultores podem estar sob-risco de exposição química mesmo que apenas um desses produtos seja utilizado na agricultura em alguma das propriedades visitadas. Também foi perceptível nas falas o uso concomitante entre agrotóxico extremante tóxico e outros com menos teor toxicológico.

A tabela 3 também ilustra os principais agrotóxicos utilizados pelos agricultores do estudo, o grupo químico e a classe a qual pertencem, e o numero de propriedades que faz uso do composto. É importante mencionar que uma chácara faz uso de mais de um agrotóxico. 
RESULTADOS E DISCUSSÃO

\begin{tabular}{cccc}
\hline \multicolumn{4}{c}{ Tabela 2. Agrotóxicos utilizados pelos agricultores da Chapadinha } \\
\hline Grupo Químico & Classe & Classificação Toxicológica & $\begin{array}{c}\mathrm{N}^{\circ} \text { propriedade que } \\
\text { faz uso }\end{array}$ \\
\hline Piretróide & Inseticida & Altamente tóxico - II & 6 \\
\hline Organofosforados & Inseticida & Medianamente tóxico - III & 3 \\
\hline Bipiridílios & Herbicida & Extremamente tóxico - I & 3 \\
\hline Glicina substituída & Herbicida & Pouco tóxico - IV & 2 \\
\hline Estrobilurinas & Fungicida & Medianamente tóxico - III & 2 \\
\hline Benzimidazol & Fungicida & Altamente tóxico - II & 2 \\
\hline Triazól & Fungicida & Extremamente tóxico - I & 2 \\
\hline Avermectina. & Inseticida & Extremamente tóxico - I & 3 \\
\hline Ditiocarbamatos & Fungicida & Pouco tóxico -IV \\
\hline
\end{tabular}

Fonte: Dados da Pesquisa (2015).

As Unidades Temáticas Centrais ou Núcleos de Sentido definiram-se a partir da análise detalhada dos discursos dos participantes, intitulando-se " $\mathrm{O}$ trabalhador rural e o contato com agrotóxicos"; "Saúde do agricultor".

Para possibilitar uma discussão mais aprofundada acerca dos referidos núcleos, mediante a técnica de Análise de Conteúdo na Modalidade Temática, emergiram duas categorias de cada núcleo, permitindo assim um melhor direcionamento do estudo.

\subsection{NÚCLEO DE SENTIDO I: O TRABALHADOR RURAL E O CONTATO COM AGROTÓXICOS}

A análise do conteúdo das entrevistas possibilitou o agrupamento das percepções das participantes com relação às implicações sofridas pelos agricultores em relação à exposição ao agrotóxico, assim como os cuidados adotados pelos trabalhadores para proteger dos possíveis riscos que a exposição ao agrotóxico pode causar, constituindo as categorias: "As percepções dos agricultores sobre a exposição ao agrotóxico"; "Cuidados individuais e coletivos adotados pelos trabalhadores", as quais serão apresentadas e discutidas a seguir.

\subsubsection{Categoria I: As percepções dos agricultores sobre a exposição ao agrotóxico}

O ambiente de trabalho dos agricultores possui fatores prejudiciais à sua saúde, como a exposição aos agrotóxicos, os quais podem causar desordem do sistema reprodutivo, 
infertilidade, baixo desempenho cognitivo, problemas psicológicos, dentre outros (PASIANI, 2012; BENEDETTI et al., 2013) .

Além disso, esses compostos são capazes de desencadear o desenvolvimento de doenças crônicas, doenças degenerativas e malformações congênitas (RIBEIRO et al., 2013). É importante mencionar que a intensidade dos sinais e sintomas de intoxicação pelo agroquímico pode variar dependendo do grau de intoxicação, via de absorção, características específicas dos pesticidas, práticas de cultivo; e fatores individuais, tais como: idade, sexo, estado nutricional e saúde geral (CORRÊA; SALGADO, 2011; SOBREIRA; ADISSI, 2003).

Karunamoorthi, Mohammed e Wassie (2011) evidenciam em seu estudo, que para manter a produção, os trabalhadores rurais fazem uso excessivo do agrotóxico, tendo como consequência sinais e sintomas típicos da intoxicação.

Situação semelhante foi encontrada no estudo da Chapadinha/DF, visto que os entrevistados abordaram a necessidade do uso do agrotóxico na lavoura para atender a demanda de mercado.

A dificuldade de produzir e conservar a lavoura sem o produto químico foi uma das principais reclamações dos agricultores, pois, de acordo com os participantes, o agrotóxico é fundamental na proteção das lavouras contra as pragas, além de aumentar a produção visando suprir as necessidades alimentares da população. Tais aspectos contribuíram para aderência dos agricultores à uma tecnologia baseada no agrotóxico como pode ser constatado nas falas a seguir.

Bem, eu acho que se não usar fica mais difícil para a gente produzir, [...] aí quando você começa a plantar, que faz aquele espaço todo daquela planta, as praga começam a atacar, e você tem que usar agrotóxico nele (TRI).

É importante usar sim, porque eu acho que o alimento orgânico ele não consegue alimentar a população, que é muita gente (TR2).

De acordo com Fassa ${ }^{20}$, os trabalhadores rurais do sul do Brasil explicitam o sacrifício e o grande empenho que a produção sem agrotóxico exige. Segundo eles, para obtenção de maior produção de tabaco exigida pelo mercado consumidor, é preciso uso de agrotóxicos. O composto químico é o recurso mais acessível utilizado para tentar controlar o aparecimento de pragas e compensar a perda de produção (FASSA , 2014).

A preocupação dos trabalhadores é observada durante os relatos sobre a pulverização. Segundo os entrevistados, este é o momento que mais estão expostos ao composto, surgindo daí a possibilidade de intoxicar-se ou adoecer. Nesse sentido, evidencia- 
se que quando este tipo de situação desenvolve-se, como no presente estudo, os trabalhadores rurais experimentam conflitos e sentimentos de angústia; pois a redução da produção é uma forma de prejuízo vivenciada pelos agricultores.

[...] a hora que eu estou pulverizando a roça, porque tem a questão do vento. [...] acha que é brincadeira e adoece (TR1).

[...] quando a pulverização é feita fica muito exposto [...] e a pulverização é importante pra lavoura, se não a gente não dá conta de plantar o tanto que o comprador pede. [...] mas se a gente ficar por muitos anos na pulverização, a gente pode ter intoxicação no sangue, a doença do câncer (TR2).

Na pulverização, que ventando pode vim o veneno, mesmo que você estiver com a roupa pode pegar no seu corpo [...] ]é dor de cabeça na certa [...] ficar sem trabalhar no outro dia atrasa tudo (TR3)

Assim, na hora que a gente tá pulverizando e o vento vem e pode jogar o veneno na cara da gente, né? Ai a gente pode adoecer, pode até ter o câncer no futuro[...] no outro dia a gente não vai poder trabalhar e é uma pessoa a menos [...] ai cai a produção (TR4)

Bom, eu acho que na pulverização a gente fica mais exposto, porque o vento muda muito de direção e também porque a gente fica muito tempo pulverizando a plantação, fica em contato por muito tempo com o agrotóxico. [...] as informações que chegam para a gente é que pode causar câncer, pode causar vários tipos de doença (TR6).

Os estudos de Gregolis, Pinto e Peres (2012) fazem uma associação entre o fato dos trabalhadores rurais fazerem referência a pulverização como a etapa de maior perigo do processo produtivo, com a visibilidade dos riscos, pois é durante essa etapa que o maior volume de agrotóxicos é visto e aplicado em áreas grandes.

Um estudo realizado em Bangladesh informa que $87 \%$ dos seus agricultores que usam os agrotóxicos na pulverização em culturas comerciais são altamente vulneráveis a várias doenças (MIAH et al., 2014). Independentemente do trabalho envolver ou não, a utilização direta de pesticidas, a presença de tais produtos químicos no ambiente de trabalho já consiste na potencial exposição ocupacional. Evidentemente, grupos de trabalhadores que estão envolvidos na pulverização são normalmente considerados de maior exposição e, portanto, com maior risco de possíveis intoxicações (GIL; SINFORT et al., 2008).

Em suma, esta categoria de análise demonstrou as percepções apresentadas pelos agricultores sobre a necessidade do agrotóxico para o aumento da produção agrícola e também destacaram a pulverização como a etapa do processo de produção em que mais estão expostos ao produtos químicos e suas consequências. 
RESULTADOS E DISCUSSÃO

\subsubsection{Categoria II: Cuidados individuais e coletivos adotados pelos trabalhadores}

A proteção individual e coletiva contra os agrotóxicos no processo de produção é algo perceptível em muitos estudos (BURKETT et al., 2013; LESMES-FABIAN et al., 2013). As medidas de proteção individual são as atitudes adotadas pelos trabalhadores visando evitar que eventos indesejáveis ofereçam perigo à integridade física e à saúde do agricultor (KELLEY et al., 2013; BROWN et al., 2012).

Entretanto, os participantes do estudo associaram à proteção individual apenas o uso do Equipamento de Proteção Individual (EPI), um entrevistado relacionou a proteção individual ao cuidado com a direção do vento. Nas falas a seguir também percebeu-se a utilização inadequada dos EPI's, visto que eles não fazem o uso de todos os itens do EPI, o que seria o ideal para ter a proteção total.

"praticamente eu não cuido de mim, eu uso calça, uso botas, e procuro estar sempre do lado do vento" (TR1).

"Eu uso a Bota, calça, camisa, avental, luvas, mascara [...] quando não está ventando a gente não usa a viseira que embaça" (TR6).

"Uso a máscara, tem aquela viseira, e a camisa de mangas compridas, a calça com a parte que não deixa passar o veneno [...]” (TR7).

"A gente usa as roupas que tem aquela EPI [...] e ainda usa máscara, ainda usa um pano também para cobrir o rosto, a camisa, luvas, botina" (TR10).

Os EPI's, na maioria das vezes, não são desejados pelos os agricultores familiares da Chapadinha, pois os entrevistados mencionam o incômodo causado por estes, tais como falta de ar e calor intenso, além de alguns atrapalharem suas atividades laborais.

"[...] aquilo incomoda, demora você... Eu trabalhava numa chácara que o rapaz lá forneceu para a gente bota, a roupa, a máscara, mas o jeito que a gente trabalhava não aguentava, abafa aquele calor, a bota sua, se bota a máscara, a máscara, devido ao movimento que você faz cansa, começa a cansar e a respiração não fica solta, então prende a respiração" (TR1).

"[...] é um pouco desconfortável, mas a gente tem que usar, é quente, como eu falei, embaça, mas a gente está aos poucos se conscientizando, a gente passou muito tempo sem usar [...] a gente vai se conscientizando, ele é essencial" (TR4).

"[...] mas é porque é muito ruim ficar sem respirar direito e morrendo de calor com a roupa" (TR9). 
RESULTADOS E DISCUSSÃO

Um estudo desenvolvido no Município de Pelotas (RS) apresenta dados semelhantes. Os fumicultores do estudo de Silva (2013) relataram a utilização de algum item do EPI, visto que, há relatos de desconforto quando utilizam o EPI por completo. De acordo com Oliveira e Machado Neto (2005), muitos agricultores realizam a pulverização sem as proteções necessárias, principalmente nos meses mais quentes do ano, visto que o mal-estar e o desconforto desencorajam os trabalhadores rurais.

Uma pesquisa desenvolvida por Almeida et al. (2011) com fumicultores demonstrou a rara utilização dos equipamentos de proteção recomendados, diante disso a pesquisadora relaciona a não utilização desses meios de proteção, de suma importância para a saúde dos agricultores, à intoxicações decorrente do contato direto com o agrotóxico. BlancoMunoz e Lacasana (2011) também pesquisaram as restrições laborais, dificuldades e obstáculos que inviabilizam à utilização dos EPI's, e constataram que os equipamentos, geralmente, são inadequados às condições ergonômicas e ambientais.

Esses dados corroboram como as informações colhidas neste estudo, tendo em vista que há divergência e contradições quanto a importância do uso do EPI pelos trabalhadores nas atividades que envolvem contato com o agrotóxico. Alguns relataram que o EPI deve ser utilizado em todos os momentos que manuseia o produto, no entanto outros agricultores mencionaram não utilizar os EPI's em algumas atividades como, por exemplo, o preparo da calda de pulverização, alegando que os EPI's dificultam o manejo retardando o preparo do produto e consequentemente atrasando o processo de produção.

"[...] em tudo que a gente for mexer que tiver veneno tem que estar com o equipamento de segurança, pra fazer a calda, pra pulverizar, pra tudo" (TR3).

“[...] na hora da calda não tenho muito cuidado com isso não [...] Às vezes eu fico sem as luvas, porque a gente vem com pressa e as luvas atrapalham um pouco para manusear os frascos" (TR7).

De acordo com a análise das falas, percebeu-se que a via dérmica dos agricultores da Chapadinha frequente é exposta ao agrotóxico durante o preparo da calda de pulverização. Existem basicamente três formas de exposição: inalatória, dérmica e a digestiva. Das três, a via dérmica corresponde a 99\% da exposição total aos agrotóxicos (PASIANI, 2012).

Diante desses dados, constata-se a importância do uso do EPI durante todo o processo de manuseio dos agrotóxicos, incluindo etapas que vão desde a preparação da calda, pulverização no cultivo e retiradas dos resíduos dos equipamentos e roupas utilizadas (VEIGA et al., 2007). 
Outras medidas de proteção individual foram relatadas pelos entrevistados, tais como a limpeza dos EPI's e o banho após o término do manuseio, retirando os eventuais resíduos do corpo. Vale ressaltar que outros cuidados como a lavagem da roupa utilizada para o manejo do agrotóxico e a limpeza de locais da casa contaminados por resíduos químicos levados pelo vento, são realizadas pelas mulheres.

"E a minha roupa eu levo pra casa e minha mãe lava. [...] Ela colocar só a minha roupa na máquina, coloca sabão e muita água, pra diminuir o agrotóxico" (TR8).

"Eu gosto de lavar e esfregar á casa [...] fico de chinelo, mas eu tenho a bota” (TR9).

Os estudos de Biazon e Baccon (2014) apresentam resultados parecidos com o deste estudo, já que os autores também apontam as mulheres como responsáveis pela lavagem das roupas contaminadas, além disso a pesquisa informa que a dificuldade de visualização dos riscos enfrentados pelas mulheres ao desenvolver esta atividade, contribuindo assim para sua exposição somatória. Desta maneira são necessárias ações educativas voltadas para o público, principalmente o feminino, visto que indiretamente estão expostas aos mesmos riscos que acometem os aplicadores do produto.

Sabe-se que existem alguns critérios a serem seguidos no que tange a prevenção das intoxicações dos trabalhadores rurais, tais como: lavar as roupas contaminadas separadamente das roupas comuns, logo após o dia de trabalho; utilizar luvas e avental para manusear as roupas e EPI's contaminados e realizar a pré-lavagem dos insumos contaminados antes da lavagem propriamente dita (VEIGA et al., 2007).

É importante mencionar que a lavagem da roupa deve ser feita apenas com água e sabão, que será suficiente para diluir e neutralizar os resíduos do produto. Destaca-se também a necessidade da limpeza adequada do tanque e da máquina de lavar (VEIGA et al., 2007).

Os agricultores estudados ainda demonstram em suas falas atitudes voltadas para o cuidado com a saúde da comunidade e o meio ambiente. Um informante relatou fazer a leitura do rótulo antes da aplicação do produto, pois ao seguir tais instruções, o participante da pesquisa acredita estar protegendo o meio ambiente e a saúde da comunidade, pois o consumidor pode adquirir o alimento com resíduos de agrotóxico caso não respeite o período de carência.

O rótulo contém informações sobre as culturas específicas para o agrotóxico; as dosagens para cada situação; a época em que o agrotóxico deve ser usado e o período de 
carência, ou seja, o intervalo de tempo, em dias, que deve ser observado entre a aplicação do agrotóxico e a colheita do produto agrícola (BRASIL, 2005).

"[...] a gente tem que respeitar o prazo do veneno, do agrotóxico, e se é três dias, vamos colocar três dias para poder colher, e muitas vezes o produtor não respeita, e você vai fazer uma pesquisa está lá o produto com agrotóxico, porque faltou respeitar o prazo" (TR2).

"[...] cuidado pra pulverizar na estação certa [...] tem produto que é pra aplicar só no início da plantação, outros só podem quando tem uma situação mais grave, essas coisas a gente deve seguir, pra não prejudicar os outros animais [...]” (TR5).

"[...] sempre a dosagem aquilo que pede na bula, pra não ficar forte... Quando eu fiz o curso da Emater, eles mostraram como o ambiente fica contaminado se a gente não tiver cuidado... [...] não colocar o veneno que é de uma planta em outra [...], por exemplo, tem vez que sobra o veneno da abobrinha e o produtor pega e coloca no morango, pra não estragar" (TR7).

Nota-se que apesar de muitas vezes esses agricultores negligenciarem o cuidado especifico com a sua saúde, através do uso parcial dos EPI's, eles demonstram preocupação no que diz respeito a outros cuidados específicos para o ambiente e população em geral, como exemplo, seguir a risca as informações contidas nos rótulos. Respeitar as orientações contidas na bula pode significar produtos agrícolas com menos resíduos químicos, respeitando o limite máximo permitido pelo Ministério da Saúde (UYEDA et al., 2012).

Sobre esse assunto, um estudo realizado por Vinha et al. (2011) evidenciou alto percentual de irregularidades no uso de agrotóxicos no Brasil, que são comprovadas pela presença de resíduos de agrotóxicos proibidos ou acima dos limites permitidos em frutas e hortaliças. Deste modo esses pesquisadores apontaram a necessidade da sensibilização dos agricultores para importância de seguir a risca as informações da bula.

O armazenamento e o descarte das embalagens de agrotóxicos vazias também foram itens apresentados pelos agricultores quando questionados sobre os cuidados de proteção à saúde da comunidade. No entanto, as falas revelam sentimento de dúvidas quanto ao tema e diante da situação, foi observado que as ações de descarte dessas embalagens nem sempre são realizadas de forma correta.

Verificou-se que parte dos agricultores realiza a devolução das embalagens de agrotóxicos, sendo aspecto positivo, tendo em vista que a reutilização destas pode prejudicar tanto a saúde das pessoas, como o meio ambiente. 
"Têm um postinho perto de Brazlândia que a gente devolve, junta ali mais ou menos seis meses, um ano e aí vai lá e devolve [...] A gente lava com água, só com água, três vezes... e fura o fundo" (TR6).

"eu junto todas as vasilhas [...] faço aquela lavagem de três vezes, guardo e depois deixo lá no lugar certo pra receber [...] que enviam pra reciclagem” (TR 7)

Apesar de devolverem os recipientes, muitas vezes, não são adotados alguns cuidados necessários e de suma importância como a tríplice lavagem e a perfuração no fundo dos vasilhames, conforme pode ser observado nas falas que seguem: “As embalagens eu entreguei para o pessoal que veio recolher [...] o
restante está tudo guardada lá dentro da sacola [...] longe de casa. [...] lavo
com água [...] só uma vez" (TR1).

"A gente junta e devolve lá em Brazlândia [...] eu guardo no quarto ali, longe da casa. [...] a gente só joga água dentro e balança, passa uma água para tirar o forte e depois fura" (TR4).

“[...] coloca dentro de um saco e joga lá no meio do mato [...]” (TR9).

Um estudo realizado no Paraná no ano de 2013 observou um aumento significativo nas devoluções das embalagens vazias de agrotóxicos, depois de que o governo desenvolveu campanhas educativas utilizando a mídia como ferramenta de divulgação (SOUZA et al., 2013).

A Lei $\mathrm{n}^{\circ}$ 7.802, de 11 de julho de 1989 determina as responsabilidades compartilhadas entre agricultores, canais de distribuição, cooperativas, industrias e poder público quanto ao destino final das embalagens vazias de agrotóxicos. A devolução das embalagens vazias dos produtos devem ser realizadas de acordo com as instruções previstas nas bulas, no prazo de até um ano, contado da data de compra (BRASIL, 2002).

Em suma, essa categoria de análise aponta para a necessidade de ações educativas capazes de sensibilizar os agricultores para o uso correto e completo dos EPI's. Ademais, ampliar o olhar desses profissionais para outros cuidados com a comunidade, meio ambiente e população como um todo.

\subsection{NÚCLEO DE SENTIDO II: SAÚDE DO AGRICULTOR}

A partir da análise dos relatos obteve-se um núcleo de sentido intitulado "Saúde do agricultor”. Para possibilitar uma discussão mais aprofundada acerca do referido núcleo 
emergiram duas categorias as quais referem-se sobre os sinais e sintomas relatados pelos agricultores, como também retratam acerca da percepção dos agricultores sobre a saúde.

São elas: "Concepção dos agricultores sobre a saúde"; "Sinais e sintomas relatados pelos trabalhadores".

\subsubsection{Categoria I: "Concepção dos agricultores sobre a saúde"}

A visão de saúde expressa nas falas desses agricultores entrevistados está vinculada remetem a uma associação da saúde com a ausência de doença, referindo-o como um de seus principais determinantes. Para eles os parâmetros de saúde há, necessariamente, relação com a doença, sua ausência ou cura. Como pode ser observado nas falas a seguir:

"Saúde para mim é quando não tenho doença... eu não sinto nada... eu acho que tenho saúde sim."(TR2)

"Eu acho que é você estar se sentindo bem, sem dor nenhuma, sem febre."(TR5)

Outros estudos apontam relatos sobre o conceito de saúde baseado na explicação biomédica. Percebe-se que a visão do problema de saúde e os comportamentos de busca de saúde se ativam unicamente quando a dor, a infecção ou a moléstia estão presentes (BUDÓ; GONZALES; BECK, 2003).

Outro aspecto observado nas entrevistas está ligado ao conseguir cumprir o dever, através da realização de seu trabalho. Desta forma, o trabalho possui relevância como um indicador de saúde para esse público participante do estudo.

"Para mim saúde é poder jogar bola, dormir bem, comer bem, para mim estou com saúde.” (TR2)

"Saúde é umas partes mais importantes que nós temos na nossa vida, sem ela, a gente não consegue trabalhar, não consegue cuidar da roça e nem fazer quase nada."(TR3)

"Saúde é poder trabalhar... pra sustentar minhas filhas." (TR8)

Assim como no presente trabalho, os estudos de Gomes e Aguiar (2006), desenvolvidos com trabalhadores rurais de Lafaiete Coutinho-BA, apresentam a saúde como uma máquina produtiva, capaz de gerar o sustento familiar, pois segundo as autoras, a ausência de um corpo sadio significa na falta de disposição para o trabalho, isto é, falta de produtividade. 
Segundo Bedor et al. (2009) o conceito de saúde, sob a ótica dos agricultores de Maringá, também é atribuído ausência ou presença de doença, pois de acordo com este trabalhadores rurais a doença astá relacionada à incapacidade para o trabalho.

A saúde é representada como uma sensação de bem estar adquirida pela inexistência de sintomas que impossibilite o trabalhador de realizar suas atividades cotidianas. Segundo os agricultores, saúde é sentir-se útil para família, o que parece estar fortemente relacionado com uma concepção de corpo produtivo e ao valor que tem para uma comunidade da zona rural que atua na provisão da subsistência própria e da família.

Nessa categoria captaram-se, também, os significados atribuídos às ações do Estado com relação à saúde. Os comentários demonstraram críticas nas ações das políticas públicas da Saúde, que estão distantes das necessidades dessa população entrevistada, informa a necessidade na melhoria da assistência à saúde.

"A gente não tem saúde para nos ajudar... você chega num posto e você mora numa área que eles não querem atender... então isso é difícil para a gente, é complicado."(TR4)

"Saúde é eu poder ter um acompanhamento, aonde eu chegar, no posto, no hospital... que cuide de mim quando eu precisar.... E aqui não tem."(TR6)

"Saúde .... Deveria ser uma coisa melhor... esses governos deveriam cuidar melhor da saúde da gente, porque é uma tristeza, é um sofrimento mesmo .... a gente aqui não tem quase prioridade em nada.... Eu não consigo tratamento pra ela e nem pra mim, quando tô com depressão. ”(TR9)

Uma pesquisa realizada entre trabalhadores rurais na região serrana do Rio Grande do Sul revelou vários riscos ocupacionais (riscos relacionados ao uso do agrotóxico) e altas prevalências dos problemas de saúde, esses dados alertaram para a necessidade de se priorizar ações públicas para proteção da saúde do trabalhador rural (FARIA; FACCHINI; FASSA, 2000).

Segundo o autor acima, deveriam ser promovidas ações que contribuam com a formação dos profissionais de saúde sobre problemas de saúde de origem ocupacional em populações rurais, assim como melhoria na assistência ambulatorial e hospitalar para os trabalhadores rurais. 
RESULTADOS E DISCUSSÃO

\subsubsection{Categoria II: Sinais e sintomas relatados pelos trabalhadores}

Os sinais e sintomas do processo de adoecimento dos trabalhadores rurais geralmente não são correlacionados ao contato frequente com agrotóxicos, o que contribui pra as subnotificações. Corroborando com esse fato, a Pesticide Action Network (2014) informa que o número de intoxicações por agrotóxicos em todo o mundo não pode ser estimado, visto que sua notificação é abaixo do esperado. No entanto, o referido estudo conjectura que o número de pessoas afetadas anualmente no planeta pode chegar a 41 milhões.

No Distrito Federal, durante o período de julho de 2004 a dezembro de 2007, foram registrados 1.085 casos de intoxicações ao Centro de Informação e Assistência Toxicológica do Distrito Federal, Brasil, esses registros foram principalmente nos hospitais da zuna rural (REBELO; CALDAS; HELIODORO et al., 2011).

No presente estudo os trabalhadores entrevistados relataram alguns sintomas, como prurido e rubor na pele após o manuseio com algum objeto contaminado ou o próprio composto químico.

"Eu ficava espirrando que dentro do nariz incha [...] dá muito pigarro, esse Decis ele dá muito isso, o Polytrin também, [...]eu ganhei uns herbicidas do meu pai e eu fui com a mão, eu passei assim mais ou menos uns dois dias com a mão assim, queimando e coçando" (TRl).

"[...] quando lavei a roupa dele, essa parte aqui da minha mão e essa aqui do braço ficou vermelho" (TR3).

"[...] toda vez que entro com a roupa da pulverização minha mulher começa a arder o olho [...]" (TR6).

"[...] muita vezes eu sinto dor no estômago, depois da aplicação [...] Ardência no olho, fico tonto, minha garganta fica seca, ardendo" (TR10).

De acordo com o Ministério da Saúde o quadro clínico da intoxicação aguda leve é caracterizado por cefaleia, irritação cutaneomucosa, dermatite de contato irritativa ou por hipersensibilidade, náusea e discreta tontura (BRASIL, 1997). Já a intoxicação aguda moderada apresenta a cefaleia intensa, náusea, vômitos, cólicas abdominais, tontura mais intensa, fraqueza generalizada, parestesias, dispneia, salivação e sudorese aumentadas. $\mathrm{Na}$ intoxicação aguda grave os sintomas são mais bem definidos, como a miose, hipotensão, arritmias cardíacas, insuficiência respiratória, edema agudo de pulmão, pneumonite química, convulsões, alterações da consciência, choque, coma, podendo evoluir para óbito (REBELO; CALDAS; HELIODORO et al., 2011). 
RESULTADOS E DISCUSSÃO

Estudo realizado na comunidade rural de Campo Mourão, Paraná, demonstrou que quando os agrotóxicos são aplicados nas lavouras através da pulverização, $54 \%$ dos trabalhadores apresentam sintomas, como dor de cabeça, lacrimejamento, tontura e problemas dermatológicos (BIAZON; BACCON, 2014). Outro estudo aponta dados semelhantes ao informar que mais da metade dos entrevistados tiveram algum problema de saúde relacionado à pulverização dos agrotóxicos, tendo como sintomas agudos mais frequentes os problemas estomacais e dores de cabeça (SOUZA; SOUZA; VOSGERAU, 2013).

Todos os agricultores entrevistados responderam nunca terem procurado assistência médica devido a problemas relacionados ao agrotóxico. No entanto, todos responderam positivamente ao serem questionados sobre algum tipo de hospitalização ou internação em algum momento da sua vida no campo. Relataram a busca pelo serviço de saúde devido a sintomas como tosse persistente, dor de cabeça intensa e problemas gástricos, o que pode estar relacionado a intoxicação pelo agrotóxico.

"Quando eu tava com uma tosse, essa tosse não passava de jeito nenhum, pensava que era gripe, daquelas forte, mas o médico disse que era tosse alérgica" (TR4).

"porque eu senti dor de cabeça, ai fu no medico, ai deu enxaqueca" (TR6).

"Eu já fui no postinho porque sentia muita dor no estômago [...] acabei indo no médico que mexe com isso e ele falou em gastrite[...] tomo o remédio, mas mesmo assim, ainda sinto uma coisinha aqui outra ali" (TR10).

No entanto, os sintomas apresentados nas falas merecem atenção, pois podem estar relacionados ao contato com o agrotóxico. Porém os agricultores familiares e os trabalhadores da saúde da região não fizeram associação entre os sintomas apresentados e o contato contínuo com os compostos químicos. Corroborando com os dados supracitados um estudo realizado na comunidade ribeirinha do Rio dos Sinos destaca que $93 \%$ dos trabalhadores não relacionam seus problemas de saúde à exposição ao agrotóxico, além de relatar não apresentar problema de saúde decorrente do uso de defensivos (RAMBOW; PANICHI; FIGUEIREDO, 2014).

Problemas relacionados à saúde mental também foram identificados nesta pesquisa, quando uma participante relatou ter recebido um diagnóstico de depressão. A entrevistada também demonstrou um sentimento de inutilidade na produção, visto que a doença gera incapacidade laborativa e consequente perda na produção. 
RESULTADOS E DISCUSSÃO

"[...] o médico me disse que é depressão. [...] é difícil eu dormir de noite, aí todo dia eu fico cansada e não dá vontade de você fazer nada, aí quando eu tô ruim, meu marido deixa de fazer as coisas na roça pra fazer as coisas dentro de casa, isso é ruim, porque atrasa o serviço dele lá na roça [...] já fiquei no hospital por causa dessa depressão" (TR9).

Pesquisas relatam associações entre o contato com pesticidas e depressão (SCARDOELLI et al., 2012). Associado a isso vários estudos trazem o suicídio como uma das consequências mais graves. Investigação realizada por Gunnell et. al. (2007) informa que aproximadamente 258 mil mortes por auto-envenenamento de agrotóxicos por anualmente, sendo responsável por $30 \%$ de suicídios no mundo.

No estado do Paraná foi desenvolvido um estudo, que analisou 425 casos de intoxicações no período de 1997 a 2006. As intoxicações foram mais prevalentes no sexo masculino (75,3\%) e na faixa etária de 15 a 49 anos (83\%), tendo como circunstância principal as tentativas de suicídio, com $49 \%$ dos casos, seguidas da exposição ocupacional, com 42,1\% dos casos (SCARDOELLI et al., 2012).

Para melhor abordar a temática, a pesquisa desenvolveu o estudo das amostras sanguíneas, contatando que do total de 66 análises realizadas, somente um exame apresentou o valor abaixo do valor de referência que estabelece 4620 U/L a $11500 \mathrm{U} / \mathrm{L}$ para homens e $3930 \mathrm{U} / \mathrm{L}$ a $10800 \mathrm{U} / \mathrm{L}$ para mulheres como faixa de concentração considerada normal para a colinesterase plasmática. Os demais 65 exames apresentaram os valores dentro da faixa de concentração normal.

Sabe-se que a diminuição da atividade da colinesterase plasmática se dá quando há disfunção hepática (cirrose), baixa concentração da enzima (má nutrição), neoplasia, insuficiência cardíaca, reações de hipersensibilidade, infecções agudas e agudas e em decorrência de exposição aos agrotóxicos das classes dos organofosforados e carbamatos $^{44}$. Sendo que a ação desses agrotóxicos no organismo pode permanecer, em media, por trinta dias em caso de intoxicação aguda (PASIANE, 2012).

Os organosfosforados atuam no organismo humano através da inibição das enzimas colinesterásicas ( $\mathrm{AChE}$ e $\mathrm{BChE}$ ), devido a localização das enzimas, a $\mathrm{AChE}$ na membrana eritrocitária e a $\mathrm{BChE}$ no plasma, os sintomas de intoxicação são associados apenas à redução da $\mathrm{AChE}$. Com a enzima em concentrações baixas, o tempo de permanência da acetilcolina nos terminais nervosos é prolongado, o que acarreta em problemas no impulso nervoso (MARONI et al., 2000).

Quanto às manifestações clínicas provocadas pelo excesso de aceticolina, pode-se citar: a) efeitos muscarínicos - anorexia, náuseas, vômitos, dores abdominais, aumento da 
amplitude das contrações e peristaltismo gastrointestinais, diarréia, aumento da secreção das glândulas exócrinas com sudorese excessiva, sialorréia, lacrimejamento e distúrbios respiratórios como dispnéia, cianose e acúmulo de secreções 11 nos brônquios, podendo levar ao edema pulmonar agudo; b) efeitos nicotínicos - tremores de língua, lábios, olhos, espasmos e fasciculações musculares, seguidas por flacidez e paralisia; c) Sistema Nervoso Central cefaléia, tontura, tremores, ataxia, distúrbios da palavra, convulsões tônico-clônicas e coma (PASIANE, 2012).

A função da BChE ainda são desconhecidos, parecendo estar relacionada ao metabolismo de lipídios, condução nervosa lenta, controle da permeabilidade de sódio e outros íons pela membrana e regulação dos níveis de colina e acetilcolina, que podem inibir a AChE. Desta forma, a BChE também é considerado um biomarcador de efeito da exposição à agrotóxicos inseticidas organofosforados e carbamatos (PASIANE, 2012).

Corroborando com o parágrafo anteior, um estudo populacional, realizado anteriormente no laboratório de Polimorfismos e Ligação - UFPR foi demonstrado que a variabilidade da $\mathrm{BChE}$, determinada geneticamente, influencia na susceptibilidade à inibição da Acetilcolinesterase eritrocitária (AChE) (SILVA; MAIA, 1996).

No Brasil, a Norma Regulamentadora $n^{\circ} 7$ do Ministério do Trabalho (NR7) que normaliza os parâmetros laboratoriais no monitoramento biológico e estabelece o biomarcador de 26 agentes químicos, incluindo os organosfosforados e carbamatos. Quando há inibição maior que $30 \%$ da $\mathrm{AChE}$ e maior que 50\% da BChE indica exposição excessiva, com potencial risco à saúde. Em casos como este, o trabalhador deve ser afastado do local até normalizar o indicador biológico (BRASIL, 1978).

Aconselha-se o monitoramento biológico das colinesterases em manipuladores de agrotóxicos deve ser realizado periodicamente, a cada 6 meses e, para cada resultado encontrado, os exames deverá ser quinzenais (FUNASA, 2001).

É importante ressaltar que a análise da atividade das colinesterases não deve ser usada de maneira isolada, sendo útil quando usada como exame auxiliar, tanto para o diagnóstico clínico quanto para as ações de vigilância e acompanhamento clínico. Medidas gerais e de suporte são, como em todas as intoxicações agudas, imprescindíveis para salvar vidas (ALMEIDA, 2002).

A Figura 3 e 4 ilustram a concentração de colinesterase plasmática, em unidades/L, das agricultoras e agricultores participantes do estudo da Chapadinha, respectivamente, nos meses de outubro de 2013 e nos meses de abril de 2015. 


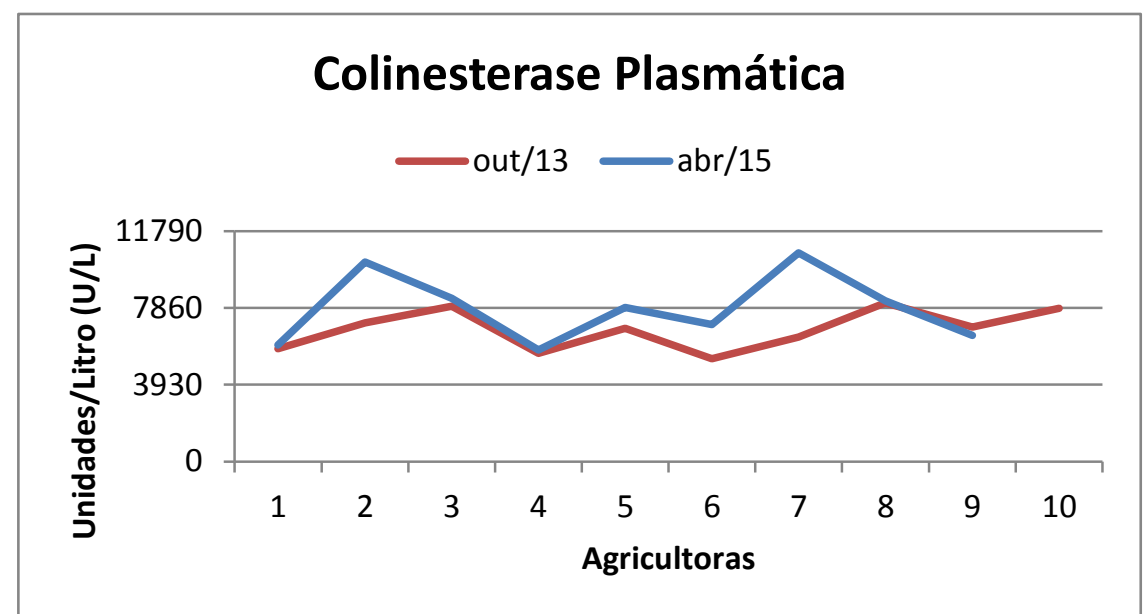

Figura 3. Concentração da enzima colinesterase plasmática nas mulheres Fonte: dados da pesquisa (2015)

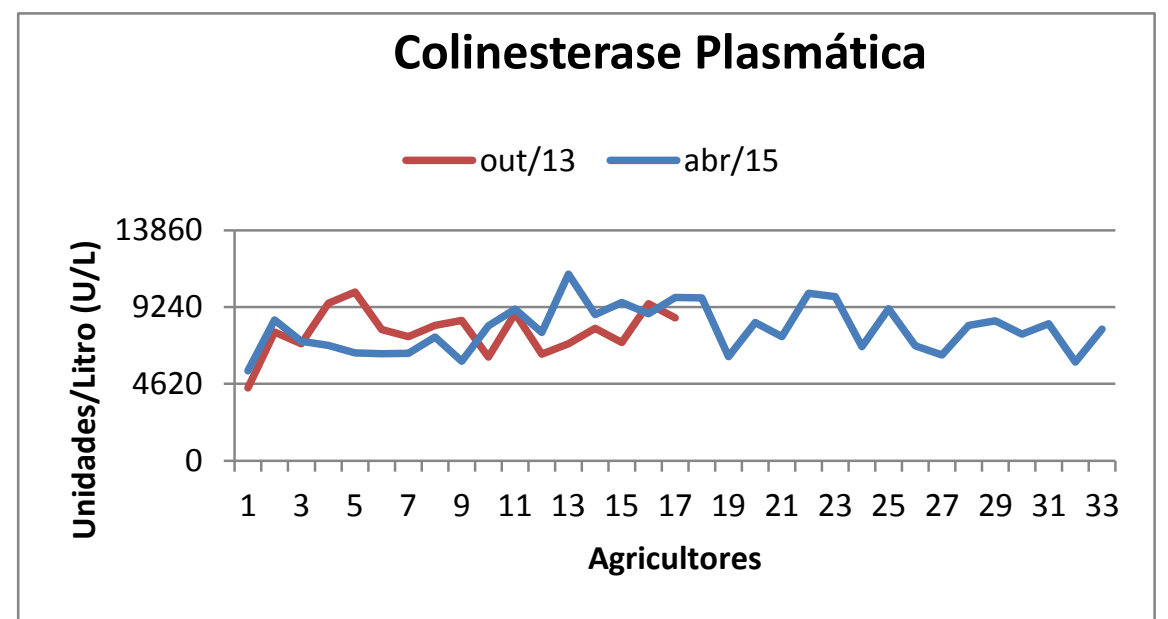

Figura 4. Concentração da enzima colinesterase plasmática nos homens Fonte: dados da pesquisa (2015)
Valor de Referência

$3930 \mathrm{U} / \mathrm{L}$ a $10800 \mathrm{U} / \mathrm{L}$

Valor de Referência $4620 \mathrm{U} / \mathrm{L}$ a $11500 \mathrm{U} / \mathrm{L}$

Os resultados destes exames toxicológicos devem ser sempre considerados em conjunto com a avaliação clínica para o diagnóstico de intoxicação e para o estabelecimento de relação de causa e efeito. Apesar de ter sido identificado nos exames laboratoriais somente um trabalhador da Chapadinha com a concentração de BChE abaixo do valor de referência, estudos diversos apontam que em várias regiões do Brasil fatos como este são mais frequentes.

Uma destas pesquisas foi realizada nos Projetos de Irrigação do Vale do São Francisco, onde foram identificados $7 \%$ de casos de intoxicação de agrotóxicos em uma amostra de 283 trabalhadores rurais (TEIXEIRA et al., 2014).

Outro estudo realizado em uma comunidade agrícola localizada em Nova Friburgo, com 102 pequenos agricultores, demostrou que a avaliação clínica realizada por 
RESULTADOS E DISCUSSÃO

profissional habilitado, diagnosticou que $72,5 \%$ dos agricultores apresentavam Efeitos muscarínicos; $68,7 \%$, Efeitos nicotínicos e 72,5\% manifestaram efeitos no Sistema Nervoso Central. Nesse mesmo estudo, a colinesterase plasmática estava reduzida em catorze agricultores do total que participou do estudo (ARAÚJO et al., 2007).

Um fato curioso é que muitos destes trabalhadores da Chapadinha referiram vários sinais e sintomas característicos da intoxicação pelo contato com o agrotóxico, porém essa intoxicação não é diagnosticada nos exames laboratoriais como pode ser constatado nas figuras 3 e 4 . Desta forma, fica nítida a importância do exame clínico associado ao exame laboratorial. 


\section{CONSIDERAÇÕES FINAIS}


No cotidiano do trabalho agrícola dos participantes da pesquisa, percebeu-se o contato entre agricultores e agrotóxico. Quando tais produtos são utilizados indiscriminadamente, evidencia-se desorganização na dinâmica natural do meio ambiente, uma vez que o agrotóxico é não seletivo e é capaz de afetar os seres não alvos, a exemplo o agricultor.

Perante a atual condição vivenciada pela relação entre a agricultura e saúde do trabalhador, são indispensáveis ações de caráter emergencial, tendo em vista melhorias nas ações fiscais para auxiliar no processo de produção agrícola, englobando aspectos como a saúde, agrotóxico e ambiente. Não defende-se neste estudo barrar o desenvolvimento científico e tecnológico alcançado até o momento no agronegócio, mas intensificar o debate e ampliar a discussão sobre seus efeitos na saúde dos trabalhadores que lidam diretamente com o agrotóxico e a população em geral.

No estudo realizado na Chapadinha-DF foi possível observar apercepção que os agricultores familiares e moradores possuem em relação ao contato com o agrotóxico. A dificuldade de produzir e manter a lavoura sem o produto químico foi uma das principais aspectos pontuados pelos entrevistados. O momento de maior exposição a riscos ocupacionais em sua atividade laboral também reflete sentimentos diversos entre os agricultores do estudo, especialmente entre os que estão à frente do processo de pulverização da plantação.

A preocupação dos trabalhadores é observada na possibilidade de adquirir uma intoxicação ou uma doença, através do contato com o produto e assim limitar a produtividade. Nesse sentido, evidencia-se que quando este tipo de situação se desenvolve, como no presente estudo, os trabalhadores rurais experimentam conflitos e sentimentos de angústia, pois a redução da produtividade é uma forma de prejuízo vivenciada pelos agricultores.

A proteção individual é associada apenas ao uso dos EPI's; apesar de terem consciência da necessidade dos EPI's para o manejo com agrotóxicos, a pesquisa apontou a falta do uso de alguns itens que compõe os EPI's, observando o incômodo causado por estes equipamentos, além de alguns atrapalharem as atividades laborais. Tendo em vista proteger a saúde da comunidade em geral, os agricultores do estudo mencionaram atitudes cuidadosas referentes à leitura do rótulo do agrotóxico, armazenamento e o descarte correto das embalagens de agrotóxicos vazias.

Todavia, as falas revelam sentimento de dúvidas quanto ao tema e diante da situação, foi observado que as ações nem sempre são realizadas de forma correta. Defende-se que as mesmas pesquisas que impulsionaram o avanço científico e tecnológico para produção 
do agrotóxico possa também ser direcionada para melhoria da qualidade do arsenal tecnológico de proteção dos agricultores.

Ainda no estudo, foi abordado também sobre a assistência à saúde recebida pelos agricultores da região e sobre a percepção dos agricultores sobre a saúde. Os trabalhadores relataram sintomas compatíveis com intoxicação por agrotóxicos após o manuseio com algum objeto contaminado ou o próprio composto químico. Todos os agricultores que participaram do estudo, responderam nunca terem procurado assistência médica devido a problemas relacionados ao agrotóxico.

No entanto, todos responderam positivamente ao serem questionados sobre hospitalizações ou internações relacionados a outros fatores; referiram a busca pelo serviço de saúde em situações como tosse persistente, dor de cabeça intensa e problemas gástricos, sinais característicos de intoxicação.

Além disso, foi discutido o adoecimento desses trabalhadores com sintomas semelhantes ao da intoxicação por agrotóxicos, no entanto os exames de colinesterase sérica apresentam-se dentro da normalidade. Essa divergência demonstra a importância do exame clínico por um profissional da saúde habilitado associado a exames complementares, como as análises laboratoriais para determinação da colinesterase.

Sugere-se que sejam pensadas ações que incentivem e estimule os agricultores a buscar com frequência os serviços de saúde para submeter-se a exames laboratoriais, como o exame de sangue que determina os níveis da butirilcolinesterase, e passar pela avaliação da equipe profissional habilitada no tema.

Ações fiscalizadoras eficientes e políticas públicas governamentais direcionadas a essas populações devem ser contínuas e podem resultar em mudanças concretas nas atitudes dos trabalhadores rurais da Chapadinha relacionadas aos agrotóxicos, além de melhorar a qualidade de vida dessas pessoas e de suas famílias.

Por último constata-se a necessidade de mais pesquisas que envolvam a saúde do trabalhador rural, pois existe um público grande de agricultores envolvidos e expostos ao perigo de intoxicações, que precisam de estratégias para minimizar os riscos e proteger sua saúde. Espera-se com este estudo ampliar o debate e gerar novas reflexões sobre o tema. 
REFERÊNCIAS

ABIQUIM [internet]. Brasil: Associação Brasileira da Indústria Química; 2014. [actualizado 07 fev. 2015; citado 10 fev. 2015]. Available from: URL: <www.abiquim.org.br/comissao/setorial/corantes-pigmentos/especificidade/historicoaplicacao $>$.

ALMEIDA, E. D.; ZIMMERMAN, M.; GONÇALVES, C. D. S; GRDEN, C.; MACIEL, M.; BAIL, L.; ITO, C. et al. Agrotóxicos e o risco à saúde entre fumicultores. Publ. UEPG Ci. Biol. Saúde, Ponta Grossa, v. 17, n. 2, p. 57-63, 2011.

ALMEIDA, Pedro José. Intoxicação por Agrotóxicos. [s. 1.]: Andrei, 2002.

ALTIERI, Miguel. Agroecologia: a dinâmica produtiva da agricultura sustentável. $5^{\text {a ed. Porto }}$ Alegre: UFRGS, 2009. 117p.

ALVES FILHO, José Prado. Uso de agrotóxicos no Brasil: controle social e interesses corporativos. Annablume, 2002.

ARAÚJO, A. C. P.; NOGUEIRA, D. P.; AUGUSTO, L. G. S. Impacto dos praguicidas na saúde: estudo da cultura de tomate. Revista de saúde pública, São Paulo, v. 34, n. 3, p. 309$13,2000$.

ARAÚJO, A. J. D.; LIMA, J. S. D.; MOREIRA, J. C.; JACOB, S. D. C.; SOARES, M. D. O.; MONTEIRO, M. C. M.; MARKOWITZ, S. et al. Exposição múltipla a agrotóxicos e efeitos à saúde: estudo transversal em amostra de 102 trabalhadores rurais, Nova Friburgo, RJ. Ciência \& Saúde Coletiva, v. 12, n. 1, p. 115-130, 2007.

AUGUSTO, L. G. S. et al. Exposição ocupacional aos agrotóxicos e riscos sócio-ambientais: subsídios para ações integradas no estado de Pernambuco. In: AUGUSTO L. A., FLORENCIO L. CARNEIRO R. M. Pesquisa (ação) em saúde ambiental: contextocomplexidade-compromisso social. Recife: Ed.Universitária, 2001. p.41-45.

BALlA, J. V. Q.; DA SILVA SANTOS, D.; OLIVEIRA, C. E. B. 12283 - Transição agroecológica na produção de morangos no Assentamento Betinho-Distrito Federal. Cadernos de Agroecologia, v. 6, n. 2, 2011.

BASTOS, L. H. P.; GOES, H. C. A.; CARDOSO, M. H. W. M.; GOUVÊA, A. V.; DIAS, D. P.; ALMEIDA, R. R. R.; et al. Ensaio de proficiência para análise de ditiocarbamatos em polpa de banana. Quimica Nova, v. 30, n. 1, p. 32, 2007.

BEDOR, C. N. G.; RAMOS, L. O.; PEREIRA, P. J.; RÊGO, M. A. V.; PAVÃO, A. C.; AUGUSTO, L. G. D. S. Vulnerabilidades e situações de riscos relacionados ao uso de agrotóxicos na fruticultura irrigada. Rev bras epidemiol, v. 12, n. 1, p. 39-49, 2009.

BELPOGGI, F.; SOFFRITTI, M.; GUARINO, M.; LAMBERTINI L, CEVOLANI D, MALTONI C. Results of Long-Term Experimental Studies on the Carcinogenicity of Ethylene-bis-Dithiocarbamate (Mancozeb) in Rats. Annals of the New York Academy of Sciences, v. 982, n. 1, p. 123-136, 2002. 
REFERÊNCIAS

BENACHOUR, N.; SÉRALINI, G. E. Glyphosate formulations induce apoptosis and necrosis in human umbilical, embryonic, and placental cells.Chemical research in toxicology, v.22, n.1, p.97-105, 2008.

BENEDETTI, D.; NUNES, E.; SARMENTO, M.; PORTO, C.; DOS SANTOS, C. E. I.; DIAS, J. F.; DA SILVA, J. Genetic damage in soybean workers exposed to pesticides: evaluation with the comet and buccal micronucleus cytome assays. Mutation Research/Genetic Toxicology and Environmental Mutagenesis, v. 752, n. 1, p. 28-33, 2013.

BERTI, Alessandra Paim; DÜSMAN, Elisângela; SOARES, Lilian Capelari. Efeitos da contaminação do ambiente aquático por óleos e agrotóxicos.SaBios-Revista de Saúde e Biologia, v. 4, n. 1, 2009.

BIAZON, Ana Carla Broetto; BACCON, Bruno Gaio. EXPOSIÇÃO A AGROTÓXICOS: PERFIL DOS TRABALHADORES DE UMA COMUNIDADE RURAL DE CAMPO MOURÃO-PR. SaBios-Revista de Saúde e Biologia, v. 9, n. 2, p. 13-19, 2014.

BLANCO-MUNOZ, Julia; LACASANA, Marina. Practices in pesticide handling and the use of personal protective equipment in Mexican agricultural workers.Journal of agromedicine, v. 16, n. 2, p. 117-126, 2011.

BOCHNER, R. Sistema Nacional de Informações Tóxico-Farmacológicas-SINITOX e as intoxicações humanas por agrotóxicos no Brasil. Cien Saude Colet, v. 12, n. 1, p. 73-89, 2007

BONATO, A. A. A fumicultura no Brasil e a convenção-quadro para controle do tabaco. DESER - Departamento de Estudos Sócio-Econômicos Rurais. Curitiba (PR), jan. 2007.

BOWLES, R. G.; WEBSTER, J. P. G. Some problems associated with the analysis of the costs and benefits of pesticides. Crop Protection, v. 14, n. 7, p. 593-600, 1995.

BRAIBANTE, M. E. F.; ZAPPE, J. A. A química dos Agrotóxicos. Química Nova na Escola, v.34, n.1, p.10-15, 2012.

BRANCO, S.M. Natureza e agroquímicos. 2. ed. São Paulo: Moderna, 2003.

BRASIL, Comissão de seguridade social e família. Câmara dos Deputados. Subcomissão especial sobre o uso de agrotóxicos e suas consequências à saúde. Brasília, DF, 2011.

BRASIL. Decreto n. 4.074, de 04 de janeiro de 2002. Regulamenta a Lei $\mathrm{n}^{\mathrm{0}} 7.802$, de 11 de julho de 1989. Brasília: Diário Oficial da União; 2002.

BRASIL. Lei n. 9.974, de 06 de junho de 2000. Altera a Lei no 7.802 , de 11 de julho de 1989 E dispõe sobre o Regimento de Custas e adota outras providências. Brasília: Diário Oficial da União; 2000.

BRASIL. Ministério da Saúde. Agência Nacional de Vigilância Sanitária. RE/ANVISA no 2606, de 11 de agosto de 2006. Dispõe sobre as diretrizes para elaboração, validação e 
implantação de protocolos de reprocessamento de produtos médicos e dá outras providências. Brasília: Diário oficial da União; 2006.

BRASIL. Ministério da Saúde. Anvisa. Programa de Análise de Resíduos de Agrotóxicos em Alimentos. Relatório complementar relativo à segunda etapa das análises de amostras coletadas em 2012. Brasília: Agência Nacional de Vigilância Sanitária; 2014.

BRASIL. Ministério da Saúde. Anvisa. Programa de Análise de Resíduos de Agrotóxicos em Alimentos. Relatório de atividades de 2010. Brasília: Agência Nacional de Vigilância Sanitária; 2011.

BRASIL. Ministério da Saúde. Levantamento dos ensaios realizados por laboratórios prestadores de serviços na área de agrotóxicos, seus componentes e afins. Pesquisa elaborada pela Gerência Geral de Laboratórios de Saúde Pública - GGLAS. Brasília, 2003.

BRASIL. Ministério da Saúde. Secretaria de Vigilância Sanitária. Manual de Vigilância da Saúde de Populações Expostas a Agrotóxicos. Brasília: Organização Pan-Americana de Saúde/Organização Mundial de Saúde; 1997.

BRASIL. Ministério da Saúde. Secretaria de Vigilância Sanitária. Manual de Vigilância da Saúde de Populações Expostas a Agrotóxicos. Organização Pan-Americana de Saúde/Organização Mundial de Saúde. Brasília: Ministério da Saúde; 1997.

Brasil. Ministério do Trabalho e Emprego - MTE. Portaria no 3.214, de 08 de junho de 1978. NR 6 - EQUIPAMENTO DE PROTEÇÃO INDIVIDUAL - EPI. Brasília: Diário Oficial da República Federativa do Brasil; 1978.

BRASIL. Ministério do Trabalho e Emprego. Norma Regulamentadora 7 - PROGRAMA DE CONTROLE MÉDICO DE SAÚDE OCUPACIONAL, 1978.

BRASIL. Ministério do Trabalho e Emprego. Portaria no 191, de 15 de abril de 2008. Norma Regulamentadora Rural 5 - Produtos Químicos. Diário Oficial da União, Brasília, 2008.

BRASIL. Ministério do Trabalho e Emprego. Norma Regulamentadora 31 - Segurança e saúde no trabalho na agricultura, pecuária silvicultura, exploração florestal e agricultura. Portaria GM n 86, de 03 de março de 2005. Brasília, DF, 2005.

BRASIL. Portaria Normativa IBAMA no 84 de 15 de outubro de 1996. Estabelece procedimentos a serem adotados junto ao Instituto Brasileiro do Meio Ambiente e dos Recursos Naturais Renováveis - IBAMA. 1996.

BROWN, Amy E.; RAMSAY, Carol; FOSS, Carrie. Pairing Epidemiological Research Results with a Practical Message to Improve Pesticide Applicators' Personal Safety Practices. Journal of Pesticide Safety Education, v. 14, p. 23-32, 2012.

BUDÓ, M. L. D.; GONZALES, R. M. B.; BECK, C. L. C. Saúde e trabalho: uma correlação de conceitos na perspectiva de uma população rural e de Christophe Dejours. Rev Gaúcha Enferm, Porto Alegre (RS), v.24, n.1, p.43-52, 2003. 
REFERÊNCIAS

BURKETT, Douglas A. et al. The Deployed Warfighter Protection (DWFP) Research Program: developing new public health pesticides, application technologies, and repellent systems. Journal of Integrated Pest Management, v. 4, n. 2, p. A1-A7, 2013.

CALLAHAN, C. L.; AL-BATANONY, M.; ISMAIL, A. A.; ABDEL-RASOUL, G.; HENDY, O.; OLSON, J. R.; BONNER, M. R. et. al.. Chlorpyrifos Exposure and Respiratory Health among Adolescent Agricultural Workers. International journal of environmental research and public health, v. 11, n. 12, p. 13117-13129, 2014.

CIESIELSKI, S.; LOOMIS, D. P.; MIMS, S. R.; AUER, A. Pesticide exposures, cholinesterase depression, and symptoms among North Carolina migrant farmworkers. American journal of public health, v. 84, n. 3, p. 446-451, 1994.

CLARK, R. F. Inseticides: Organic phosphorus compounds and carbamate. In: Goldfrank's Toxicologic Emergencies. Edited by: Flomenbaum N.E.; Goldfrank LR; Hoffman R.S.; Howland M.A.; Lewin N.A.; Nelson L.S. McGraw-Hill, pp. 1497-1512, 2006.

CNA [internet]. Brasil: Confederação da Agricultura e Pecuária do Brasil (CNA). Agronegócio acumula alta de 1,22\% no primeiro quadrimestre, CNA Biblioteca publicações; 2014. [citado 25 nov. 2014]. Available from: URL: < http://www.canaldoprodutor.com.br/sites/default/files/PIB_abril.pdf>

COLPO, Julio Cesar; NUNES, Rodolfo Navarro; ARAÚJO, Wildo Navegantes. Conhecimentos, atitudes e práticas sobre saúde do trabalhador na Coordenação de Portos, Aeroportos, Fronteiras e Recintos Alfandegados do Pará, Brasil, 2008. Vigilância Sanitária em Debate, v. 1, n. 2, p. 44-52, 2013.

CORREA, J. C. R.; SALGADO, H. R. N. Atividade inseticida das plantas e aplicações: revisão. Revista Brasileira de Plantas Medicinais, Botucatu, v. 13, n. 4, p. 500-506, 2011.

COSTA, Glauberto Moderno. Segurança do trabalhador em aplicações de herbicidas com pulverizadores de barra em cana-de-açúcar. 2007. xiii, 62 f. Dissertação (mestrado) Universidade Estadual Paulista, Faculdade de Ciências Agrárias e Veterinárias, 2007.

DA SILVA SOUZA, Cleversom; SOUZA, Cristiane Carolina Sehnem; DA SILVA VOSGERAU, Milene Zanoni. Conhecimentos e práticas na utilização de agrotóxicos e seu impacto na saúde de assentados de Jardim Alegre/PR. Divers@!, v. 6, n. 1, 2013.

DEL GRANDE, M.; REZENDE, M. O. O.; ROCHA, O. Distribuição de compostos organoclorados nas águas e sedimentos da bacia do rio Piracicaba/SP - Brasil. Quím. Nova, v.26, n.5, p.678-686, 2003.

DÉLANO-FRIER, J. P.; MARTÍNEZ-GALLARDO, N. A.; DE LA VEGA, O. M.; SALASARAIZA, M. D.; VARGAS, P.; BORODANENKO, A. The effect of exogenous jasmonic acid on induced resistance and productivity in amaranth (Amaranthus hypochondriacus) is influenced by environmental conditions. Journal of Chemical Ecology, New York, v. 30, n. 5, p. 1001-1034, May 2004.

DUKE S. O.; POWLES, S. B. Glyphosate: a once-in-a-century herbicide. Pest management Science, v.64, n.4, p.319-325, 2008. 
ECOBICHON, D. J. Toxic effects of pesticides. In: Klaassen, C.D. (Ed.) Casarett and Doull's Toxicology: The Basic Science of Poisons. McGraw-Hill, New York, pp. 763-810, 2001.

EDDLESTON, M.; BUCKLEY, N. A.; EYER, P.; DAWSON, A. H. Management of acute organophosphate pesticide poisoning. Lancet, 371: 597-607, 2008.

FAO [internet]. Roma: Food and Agriculture Organization of the United Nations (FAO). Guidelines for the management of small quantities of unwanted and obsolete pesticides, FAO Pesticide Disposal Series n.7. p. 25; 1999. [citado 25 nov. 2014]. Available from: URL: <http://www.fao.org/fileadmin/user_upload/obsolete_pesticides/docs/small_qties.pdfl>.

FARIA, N. M. X.; FACCHINI, L. A.; FASSA, A. G.; TOMASI, E. Processo de produção rural e saúde na serra gaúcha: um estudo descritivo The rural labor process and health in the Southern Brazilian mountains: a descriptive study. Cad. Saúde Pública, v. 16, n. 1, p. 115$128,2000$.

FARIA, N. M. X.; FASSA, A. G.; FACCHINI, L. A. Intoxicação por agrotóxicos no Brasil: os sistemas oficiais de informação e desafios para realização de estudos epidemiológicos. Ciência \& saúde coletiva, Rio de Janeiro, v. 12, n. 1, p. 25-38, 2007.

FASSA, Anaclaudia. Occupational exposure to pesticides, nicotine and mental health problems among tobacco farm workers in southern Brazil. In:The 20th IEA World Congress of Epidemiology (17-21 August 2014, Anchorage, AK). WCE, 2014.

FUNASA. Avaliação da Colinesterase Sanguínea Humana. [s.l.]: [s. n.], 2001.

GARCIA, E. G. Aspectos de prevenção e controle de acidentes no trabalho com agrotóxicos. São Paulo: Fundacentro, 2005.

GAWARAMMANA, I. B.; BUCKLEY, N. A. Medical management of paraquat ingestion. British journal of clinical pharmacology, v.72, n.5, p.745-757, 2011.

GIL, A. C. Como elaborar projetos de pesquisa. 3. ed. São Paulo: Atlas, 2005.

GIL, Y.; SINFORT, C.; GUILLAUME, S.; BRUNET, Y.; PALAGOS, B. Influence of micrometeorological factors on pesticide loss to the air during vine spraying: data analysis with statistical and fuzzy inference models. Biosystems Engineering, v. 100, n. 2, p. 184$197,2008$.

GILLIOM, R. J.; BARBASH, J. E.; KOLPIN, D. W.; LARSON, S. J. Peer Reviewed: Testing Water Quality for Pesticide Pollution. Environmental science \& technology, v. 33, n. 7, p. 164A-169A, 1999.

GLUSCZAK, L.; MIRON, D. S.; MORAES, B. S.; SIMÕES, R. R.; SCHETINGER, M. R. et al. Acute effects of glyphosate herbicide on metabolic and enzymatic parameters of silver catfish (Rhamdia quelen).Comparative Biochemistry and Physiology Part C: Toxicology \& Pharmacology, v. 146, n. 4, p. 519-524, 2007. 
REFERÊNCIAS

GOMES, Liane Oliveira Souza; AGUIAR, Maria Geralda Gomes. Programa de saúde da família: um espaço para a reconstrução das representações sociais do processo saúdedoença. Rev Bras Enferm, v. 59, n. 5, p. 614-9, 2006.

GREGOLIS, T. B. L.; PINTO, W. J.; PERES, F. Percepção de riscos do uso de agrotóxicos por trabalhadores da agricultura familiar do município de Rio Branco, AC. Revista Brasileira de Saúde Ocupacional, v.37, n.125, p.99-113, 2012.

GREGOLIS, Thais Blaya Leite; PINTO, Wagner de Jesus; PERES, Frederico. Risk perception associated to pesticide use among family agriculture workers in Rio Branco, Acre, Brazil. Revista Brasileira de Saúde Ocupacional, v. 37, n. 125, p. 99-113, 2012

GUERRERO, J. A.; VELANDIA, Y. Evaluacion de metodologías para el analisis de productos tóxicos de la degradación de fungicidas ditiocarbamatos. Revista Colombiana de Química, v. 42, n. 3, p. 1-21, 2013.

GUJARATI, Damodar. N, 2003, Basic Econometrics, 2008.

GUNNELL, D.; EDDLESTON, M.; PHILLIPS, M. R.; KONRADSEN, F. The global distribution of fatal pesticide self-poisoning: systematic review. BMC public health, v. 7, $\mathrm{n}$. 1, p. 357, 2007.

HEUDORF, U.; ANGERER, J. Metabolites of pyrethroid insecticides in urine specimens: current exposure in an urban population in Germany.Environmental health perspectives, $v$. 109, n. 3, p. 213, 2001.

HIRATA, R. Piretróides: estrutura química-atividade biológica. Química Nova, v. 18, n. 4, p. 368-374, 1995.

HOY, Casey W.; HEAD, Graham P.; HALL, Franklin R. Spatial heterogeneity and insect adaptation to toxins. Annual review of entomology, v. 43, n. 1, p. 571-594, 1998.

IBGE. Contagem da População 2007. Disponível em:〈www.ibge.gov.br〉. Acesso em: 12 jan. 2014.

INPEV. Inpev.org.br [internet]. Brasil: Instituto Nacional de Processamento de Embalagens Vazias - INPEV; 2007. [actualizado 07 jan. 2015; citado 23 jan. 2015]. Available from: URL: <http://www.inpev.org.br/institucional/inpev/inpev.asp>.

JACOBSON, L. S.V.; HACON, S. S.; ALVARENGA, L.; GOLDSTEIN, R. A.; GUMS, C.; BUSS, D. F. et al. Comunidade pomenara e uso de agrotóxicos: uma realidade pouco conhecida. Ciência e Saúde Coletiva, v.14, n.6, p.2239-2249, 2009.

KARUNAMOORTHI, Kaliyaperumal; MOHAMMED, Ahmad; JEMAL, Zeid. Peasant association member's knowledge, attitudes, and practices towards safe use of pesticide management. American journal of industrial medicine, v. 54, n. 12, p. 965-970, 2011.

KEGLEY, S. E.; HILL, B. R.; ORME, S.; CHOI, A. H. PAN Pesticide Database, Pesticide Action Network, North America. Oakland, CA: PAN Pesticide Database; 2014. [actualizado jun. 2014; citado 18 jan. 2015]. Available from: URL: 〈http://www.pesticideinfo.org> 
REFERÊNCIAS

KEIM, Sarah A.; ALAVANJA, Michael CR. Pesticide use by persons who reported a high pesticide exposure event in the agricultural health study.Environmental research, v. 85, n. 3 , p. 256-259, 2001.

KELlEY, M. A.; FlOCKS, J. D.; ECONOMOS, J.; MCCAULEY, L. A. Female Farmworkers' Health during Pregnancy Health Care Providers' Perspectives. Workplace health \& safety, v. 61, n. 7, p. 308-313, 2013.

KÖCHE, J. C. Fundamentos de metodologia científica: teoria e prática da pesquisa. Petrópolis: Vozes, 1997.

LESMES-FABIAN, Camilo; BINDER, Claudia R. Pesticide flow analysis to assess human exposure in greenhouse flower production in Colombia.International journal of environmental research and public health, v. 10, n. 4, p. 1168-1185, 2013.

LEVESQUE, D. L.; ARIF, A. A.; SHEN, J. Association between workplace and housing conditions and use of pesticide safety practices and personal protective equipment among North Carolina farmworkers in 2010. The international journal of occupational and environmental medicine, v. 3, n. 2 April, 2012.

LÓPEZ-ARRABÉ， J.; CANTARERO， A.; PÉREZ-RODRÍGUEZ， L.; PALMA， A.; MORENO, J. Experimental pyrethroid treatment underestimates the effects of ectoparasites in cavity-nesting birds due to toxicity. Ibis, v. 156, n. 3, p. 606-614, 2014.

LORENA, Douglas Ramos. Uso de produtos alternativos e fungicidas na cultura do morangueiro, sob condições de campo, em Brazlândia-DF. 2012. 32 f., il. Monografia (Bacharelado em Agronomia)—Universidade de Brasília, Brasília, 2012.

MACÁRIO, E. M. Complexidade e riscos no uso de agrotóxicos na agricultura: novas perguntas para velhas questões. 2001. Dissertação (Mestrado em Saúde Pública) - Centro de Pesquisas Aggeu Magalhães, Fundação Oswaldo Cruz, Recife, 2001.

MAGE, D. T.; ALAVANJA, M. C.; SANDLER, D. P.; MCDONNELL, C. J.; KROSS, B.; ROWLAND, A.; BLAIR, A. et al. A model for predicting the frequency of high pesticide exposure events in the Agricultural Health Study. Environmental research, v. 83, n. 1, p. 67$71,2000$.

MARONI, M.; COLOSIO, C.; FERIOLI, A.; FAIT, A. Organophosphorus pesticides. Toxicology, v. 143, n. 5, 2000.

MASCARENHA, T. K. S. F.; PESSOA, Y. S. R. Q. Aspectos que potencializam a contaminação do trabalhador rural com agrotóxicos: uma revisão integrativa. Trabalho \& Educação, v.22, n.2, p.87-103, 2013.

MATOS, F. A. C. Evolução, Tendência, Perspectivas e Desafio Futuro do Agronegócio da Olericultura no Brasil e Distrito Federal. EMATER/DF - Empresa de Assistência Técnica e Extensão Rural do Distrito Federal. 27 p. [serial on the internet] 2010 [cited 2014 Out. 14]. Available from: URL: <http://www.emater.df.gov.br/sites/200/229/00001806.pdf>. 
REFERÊNCIAS

MAUND, S. J.; CAMPBELL, P. J.; GIDDINGS, J. M.; HAMER, M. J.; HENRY, K.; PILLING, E. D.; WHEELER, J. R.; et al. Ecotoxicology of synthetic pyrethroids. In: Pyrethroids. Springer Berlin Heidelberg, 2012. p. 137-165

MEIRELLES, Luiz Antonio; GARRIGOU, Alain; BALDI, Isabelle. A contaminação por agrotóxicos e os Equipamentos de Proteção Individual (EPIs). Rev. bras. Saúde ocup, v. 32, n. 116, p. 57-68, 2007.

MEYER, T. N.; RESENDE, I. L. C; ABREU, J. C. Incidência de suicídios e uso de agrotóxicos por trabalhadores rurais em Luz (MG), Brasil. Revista brasileira de saúde ocupacional, São Paulo, v. 32.n, 116, p. 24-31, 2007.

MIAH, S. J.; HOQUE, A.; PAUL, A.; RAHMAN, A. Unsafe use of pesticide and its impact on health of farmers: a case study in Burichong upazila, Bangladesh. cancer, v. 21, p. 22, 2014.

MINAYO, M. C. S. O desafio do conhecimento: pesquisa qualitativa em saúde. 11. ed. São Paulo: Hucitec-Abrasco, 2009.

MIRANDA, F. S.; BORGES, B. L. Resíduos de agrotóxicos em alimentos: onde vamos parar? Cadernos de Agroecologia, v. 9, n. 3, 2014.

MOSTAFALOU, S.; MOHAMMAD, A. Pesticides and human chronic diseases: evidences, mechanisms, and perspectives. Toxicology and applied pharmacology, v. 268, n. 2, p. 157$177,2013$.

NASUTI, C.; CANTALAMESSA, F.; FALCIONI, G.; GABBIANELLI, R. Different effects of Type I and Type II pyrethroids on erythrocyte plasma membrane properties and enzymatic activity in rats.Toxicology, v. 191, n. 2, p. 233-244, 2003.

OLIVEIRA, Maurício Leite de; MACHADO NETO, Joaquim Gonçalves. Segurança na aplicação de agrotóxicos em cultura de batata em regiões montahosas. Revista Brasileira de Saúde Ocupacional, p. 15-25, 2005.

OLIVEIRA, N. P.; MOI, G. P.; ATANAKA-SANTOS, M.; SILVA, A. M. C.; PIGNATI, W. A. Malformações congênitas em municípios de grande utilização de agrotóxicos em Mato Grosso, Brasil. Revista Ciência \& Saúde Coletiva, v. 19, n. 10, 2014.

OLIVEIRA-SILVA, J. J.; ALVES, S. R.; MEYER, A.; PEREZ, F.; SARCINELLI, P. D. N.; MATTOS, R. C. O. C.; MOREIRA, J. C. Influência de fatores socioeconômicos na contaminação por agrotóxicos, Brasil. Rev Saúde Pública, v. 35, n. 2, p. 130-5, 2001.

PASIANE, Juliana de Oliveira. Conhecimentos, atitudes e práticas de trabalhadores rurais em relação ao uso de agrotóxicos e biomonitoramento da exposição. 2012. vii, 95 f., il. Dissertação (Mestrado em Ciências da Saúde)_-Universidade de Brasília, Brasília, 2012.

PERES, F.; ROZEMBERG, B.; LUCCA, S. R. Percepção de riscos no trabalho rural em uma região agrícola do estado do Rio de janeiro, Brasil: agrotóxicos, saúde e ambiente. Caderno de saúde pública, Rio de Janeiro, v. 21, n. 6, p. 1836-1844, 2005. 
REFERÊNCIAS

PERES, Frederico; MOREIRA, Josino Costa; DUBOIS, Gaetan Serge. Agrotóxicos, saúde e ambiente: uma introdução ao tema. Peres F, Moreira JC, organizadores. É veneno ou é remédio, p. 21-41, 2003.

PICANÇO, Marcelo C. et al. Manejo integrado de pragas de hortaliças. Manejo integrado de doenças, pragas e ervas daninhas. Viçosa: UFV, v. 2, p. 275-324, 2000.

PIGNATI, W. A.; MACHADO, J. M. H.; CABRAL, J. F. Acidente rural ampliado: o caso das" chuvas" de agrotóxicos sobre a cidade de Lucas do Rio Verde-MT. Cien Saude Colet, v. 12, n. 1, p. 105-114, 2007.

PINGALI, P. L. Green Revolution: Impacts, limits, and the path ahead.Proceedings of the National Academy of Sciences, v. 109, n. 31, p. 12302-12308, 2012.

RAMBOW, Camila; PANICHI, Valesca Beatriz Streppel; FIGUEIREDO, João Alcione Sganderla. Risco: a percepção da comunidade ribeirinha do Rio dos Sinos em relação ao uso de defensivos agrícolas. Revista Eletrônica em Gestão, Educação e Tecnologia Ambiental, v. 18, n. 2, 2014.

REBELO, F. M.; CALDAS, E. D.; HELIODORO, V. O.; REBELO, R. M. Intoxicação por agrotóxicos no Distrito Federal, Brasil, de 2004 a 2007 - análise da notificação ao Centro de Informação e Assistência Toxicológica. Ciênc. saúde coletiva, v.16, n.8, p.3493-3502, 2011.

REINER, E.; SIMEON-RUDOLF, V. Pyridinium, imidazolium and quinuclidinium compounds: toxicity and antidotal effects against the nerve agents Tabun and Soman. Arh Hig Rada Toksikol., v.57, n.2, p.171-179, 2006.

RIBEIRO, M. G.; COLASSO, C. G.; MONTEIRO, P. P.; PEDREIRA FILHO, W. R.; YONAMINE, M. Occupational safety and health practices among flower greenhouses workers from Alto Tietê region (Brazil). Science of The Total Environment, v. 416, p. 121$126,2012$.

RIGOTTO, R. M.; ROCHA, M. M. Pesticide use in Brazil and problems for public health. Cadernos de Saúde Pública, v. 30, n. 7, p. 1360-1362, 2014.

RIQUINHO, Deise Lisboa; HENNINGTON, Élida Azevedo. Agricultural diversification in a rural locality in southern Brazil: reflections and alternatives in compliance with the Framework Convention on tobacco control. Physis: Revista de Saúde Coletiva, v. 24, n. 1, p. 183-207, 2014.

ROSS, J. H.; DRIVER, J. H.; COCHRAN, R. C.; THONGSINTHUSAK, T.; KRIEGER, R. I. Could pesticide toxicology studies be more relevant to occupational risk assessment?. Annals of Occupational Hygiene, v. 45, n. suppl 1, p. S5-S17, 2001.

RUESS, W.; URECH, P.; EBERLE, J.; STAUB, T. Blend of mancozeb and a triazole component; fungicides. U.S. Patent n. 4.886.825, 12 dez. 1989.

SANTOS, S. P. A química dos Inseticidas (parte I). Boletim da Sociedade Portuguesa de Química, v.85, p.43-47, 2002;. 
SCARDOELLI, M. G. C.; BURIOLA, A. A.; OLIVEIRA, M. L. F.; WAIDMAN, M. A. P. Intoxicações por agrotóxicos notificadas na $11^{\mathrm{a}}$ regional de saúde do estado do Paraná. Ciência, Cuidado e Saúde, v. 10, n. 3, p. 549-555, 2012.

SILVA, G. R.; BORGES JÚNIOR, I.; FIGUEROA-VILLAR, J. D.; CASTRO, A. T. D. Chemical defense: history, warfare agent classification and action of neurotoxic agents. Química Nova, v. 35, n. 10, p. 2083-2091, 2012.

SILVA, G. R.; BORGES JÚNIOR, I.; FIGUEROA-VILlAR, J. D.; CASTRO, A. T. D. Chemical defense: history, warfare agent classification and action of neurotoxic agents. Química Nova, v. 35, n. 10, p. 2083-2091, 2012.

SILVA, J. B. D.; XAVIER, D. D. S.; BARBOZA, M. C. N.; AMESTOY, S. C.; TRINDADE, L. L.; SILVA, J. R. S. Fumicultores na zona rural de Pelotas (RS), no Brasil. Exposição ocupacional e a utilização de Equipamentos de Proteção Individual (EPI). Saúde em Debate, v. 37, n. 97, p. 347-353, 2013.

SILVA, S. E. F.; MAIA, E. C. F. A Butyrylcholinesterase variants (BCHE and CHE2 loci) associated with erythrocyte acetylcholinesterase inhibition in farmers exposed to pesticides. Hum Hered. , v.46, n.3, p.142-147, 1996.

SISINNO, Cristina LS. Disposição em aterros controlados de resíduos sólidos industriais nãoinertes: avaliação dos componentes tóxicos e implicações para o ambiente e para a saúde humana. Caderno de Saúde Pública, v. 19, n. 2, p. 369-374, 2003.

SLOVIC P. The Perception of Risk. London: Earthscan Publications, 2000.

SOARES, W.; ALMEIDA, R. M. V.R; MORO, S. Trabalho rural e fatores de risco associado ao regime de uso de agrotóxicos em Minas Gerais, Brasil. Caderno de Saúde Publica, Rio de Janeiro, v.19, n.4, p. 1117-1127, 2003

SOBREIRA, Antônio Elísio Garcia; ADISSI, Paulo José. Agrotóxicos: falsas premissas e debates. Cien Saude Colet, v. 8, n. 4, p. 985-990, 2003.

SOUZA, A. D.; MEDEIROS, A. D. R.; SOUZA, A. C. D.; WINK, M.; SIQUEIRA, I. R.; FERREIRA, M. B. C.; TORRES, I. L. D. S. et al. Avaliação do impacto da exposição a agrotóxicos sobre a saúde de população rural. Vale do Taquari (RS, Brasil). Ciênc Saúde Coletiva, v. 16, p. 3519-28, 2011.

SOUZA, C. S.; SOUZA, C. C. S.; VOSGERAU, M. Z. S. Conhecimentos e práticas na utilização de agrotóxicos e seu impacto na saúde de assentados de jardim alegre/pr. Divers@!,v. 6, n. 1, 2013.

SOUZA, M. V. Resíduos de agrotóxicos ditiocarbamatos e organofosforados em alimentos consumidos no restaurante universitário-UnB: avaliação da exposição humana. 2006. $91 \mathrm{f}$. Dissertação (Mestrado em Ciências da Saúde). Universidade de Brasília, Brasília, 2006.

SPADOTTO C. A.; SCORZA JUNIOR, R. P.; DORES, E. D. C.; Gebler, L.; MORAES, D. D. C. Fundamentos e aplicações da modelagem ambiental de agrotóxicos. Embrapa Monitoramento por Satélite. Documentos, 2010. 
SPADOTTO, Claudio Aparecido. Abordagem interdisciplinar na avaliação ambiental de agrotóxicos. Revista Núcleo de Pesquisa Interdisciplinar, São Miguel, 2006.

SPENCER, C. I.; YUILL, K. H.; BORG, J. J.; HANCOX, J. C.; KOZLOWSKI, R. Z. Actions of pyrethroid insecticides on sodium currents, action potentials, and contractile rhythm in isolated mammalian ventricular myocytes and perfused hearts. Journal of Pharmacology and Experimental Therapeutics, v. 298, n. 3, p. 1067-1082, 2001.

TEIXEIRA, J. R. B.; FERRAZ, C. E. D. O.; COUTO FILHO, J. C. F.; NERY, A. A.; CASOTTI, C. A. Intoxicações por agrotóxicos de uso agrícola em estados do Nordeste brasileiro, 1999-2009. Epidemiologia e Serviços de Saúde, v. 23, n. 3, p. 497-508, 2014.

THORN, G. D.; LUDWIG, R. A. The dithiocarbamates and related compounds. The Dithiocarbamates and Related Compounds., 1962.

UYEDA, J.; SUGANO, J.; CHOU, M. Y.; FUKUDA, S.; UCHIDA, J.; MELZER, M. et al. Major Basil Pests in Hawai 'i: Three Economically Important Basil Pests as of 2012. Plant Disease, 2012.

VEIGA, M. M.; DUARTE, F. J.; MEIRELlES, L. A.; GARRÍGOU, A.; BALDI, I. A contaminação por agrotóxicos e os Equipamentos de Proteção Individual (EPIs). Rev Bras Saude Ocup, v.32, p.57-68, 2007.

VERDI, Marta; CAPONI, Sandra. Reflexões sobre a promoção da saúde numa perspectiva bioética. Texto Contexto Enferm, v. 14, n. 1, p. 82-8, 2005.

VINHA, M. B.; DE OLIVEIRA PINTO, C. L.; PINTO, C. M. F; DE SOUZA, C. F.; DE MIRANDA SOUZA, M. R.; DE OLIVEIRA, L. L. Impactos do uso Indiscriminado de Agrotóxicos em Frutas e Hortaliças. Revista Brasileira de Agropecuária Sustentável, v.1, n.1, p.102-107, 2013.

WHO (World Health Organization) 1946. Constitution of the World Health Organization. Basic Documents. WHO. Genebra.

WILES, R.; DAVIES, K.; CAMPBELL, C. Overexposed: organophosphate insecticides in children's food. In: Overexposed: organophosphate insecticides in children's food. Environmental Working Group, 1998. 


\section{APÊNDICE 1- Termo de Consentimento Livre e Esclarecido Termo de Consentimento Livre}

\section{e Esclarecido}

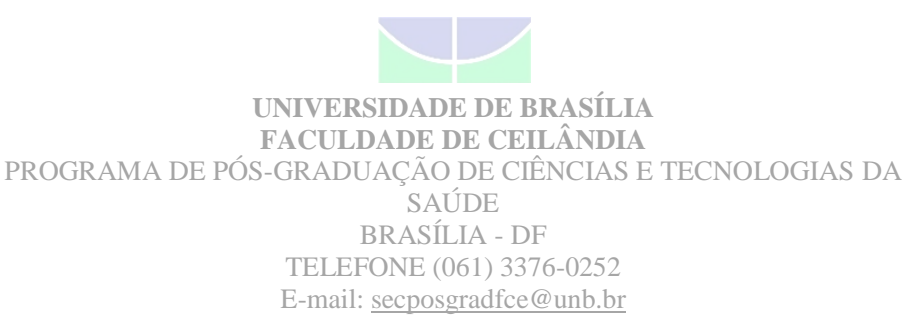

Convidamos o(a) Senhor(a) a participar do projeto de pesquisa "AGRICULTURA E SAÚDE: UMA ABORDAGEM SOBRE O PERFIL DE SAÚDE DO AGRICULTOR DA ZONA RURAL DE BRAZLÂNDIA.", sob a responsabilidade das pesquisadoras Marcela Fonseca Jonas e Maria Hosana Conceição. O projeto trata-se de uma pesquisa de campo de abordagem os agrotóxicos e que residem em chácaras do Núcleo Rural de Brazlândia, na região centro-oeste.

O objetivo desta pesquisa é delinear o perfil de saúde dos agricultores, trabalhadores e moradores da Zona Rural de Brazlândia a partir da análise dos dados referentes à exposição aos agrotóxicos.

$\mathrm{O}$ (a) senhor(a) receberá todos os esclarecimentos necessários antes e no decorrer da pesquisa e lhe asseguramos que seu nome não aparecerá sendo mantido o mais rigoroso sigilo pela omissão total de quaisquer informações que permitam identificá-lo(a)

A sua participação se dará por meio de entrevista semi-estruturada, a qual com perguntas referentes à situação socioeconômica e ao tema em questão. O encontro acontecerá em um local fora do estabelecimento de trabalho, na data combinada com um tempo estimado de 30 minutos para sua realização.

Os riscos decorrentes de sua participação na pesquisa são a possibilidade de expor de informações pessoais como sexualidade e opiniões sobre que possam lhe comprometer. Se você aceitar participar, proporcionará contribuições significativas para a área da saúde demonstrando a partir da ótica dos agricultores familiares a necessidade ou não de aperfeiçoamento de programas e desenvolvimento de projetos de educação a fim de promover o uso seguro de pesticidas no campo e proteger os agricultores e seus familiares da exposição aos agrotóxicos. Captando assim uma atenção especial das autoridades para assegurar proteção e segurança dos trabalhadores rurais no desempenho de suas atividades.

$\mathrm{O}$ (a) Senhor(a) pode se recusar a responder (ou participar de qualquer procedimento) qualquer questão que lhe traga constrangimento, podendo desistir de participar da pesquisa em qualquer momento sem nenhum prejuízo para o(a) senhor(a). Sua participação é voluntária, isto é, não há pagamento por sua colaboração.

Todas as despesas que você tiver relacionadas diretamente ao projeto de pesquisa (passagem para o local da pesquisa, alimentação no local da pesquisa ou exames para realização da pesquisa) serão cobertas pelo pesquisador responsável.

Caso haja algum dano direto ou indireto resultante dos procedimentos de pesquisa, você poderá ser indenizado, obedecendo-se as disposições legais vigentes no Brasil.

Os resultados da pesquisa serão divulgados na Faculdade Ceilândia da Universidade de Brasília podendo ser publicados posteriormente. Os dados e materiais utilizados na pesquisa ficarão sob a guarda do pesquisador por um período de no mínimo cinco anos, após isso serão destruídos ou mantidos na instituição.

Se o(a) Senhor(a) tiver qualquer dúvida em relação à pesquisa, por favor telefone para: Marcela Fonseca Jonas ou Maria Hosana Conceição, nos telefones (62) 3636-2839, (63) 8111-1903, (61) 3107-8400, (61) 8590-2631, nos horários 08:00 às 12:00 e 14:00 às 18:00.

Este projeto foi Aprovado pelo Comitê de Ética em Pesquisa da Faculdade de Ciências da Saúde (CEP/FS) da Universidade de Brasília. O CEP é composto por profissionais de diferentes áreas cuja função é defender os interesses dos participantes da pesquisa em sua integridade e dignidade e contribuir no desenvolvimento da pesquisa dentro de padrões éticos. As dúvidas com relação à assinatura do TCLE ou os direitos do participante da pesquisa podem ser obtidos através do telefone: (61) 3107-1947 ou do e-mail cepfs@ unb.br ou cepfsunb@gmail.com, horário de atendimento de 10hs às 12hs e de $14 \mathrm{hs}$ às $17 \mathrm{hs}$, de segunda a sexta-feira.

Este documento foi elaborado em duas vias, uma ficará com o pesquisador responsável e a outra com o Senhor(a).

Nome / assinatura de 
APÊNDICE 2 - Entrevista Semi-estruturada

Identificação do Trabalhador Rural - $\mathrm{N}^{\mathrm{o}}$

Data:

Sexo: ( ) Masculino ( ) Feminino

Idade (em anos completos)?

Estado civil?

Nível de Escolaridade

Renda Mensal Familiar

Há quanto tempo tem contato com os agrotóxicos?

1. O que é saúde pra você?

2. O que você acha do uso de agrotóxicos nas lavouras?

3. Você utiliza agrotóxico em sua lavoura?

4. O que você pensa sobre o uso do agrotóxico nas plantações onde trabalha e a relação com sua saúde?

5. Na sua rotina de trabalho, qual a etapa do processo de produção que usa o agrotóxico causa maior risco para saúde?

6. Alguma vez foi hospitalizado(a) ou procurou ajuda médica? E devido ao contato com o agrotóxico?

7. Qual a sua opinião sobre o uso do Equipamento de Proteção Individual (EPI) para proteger a saúde do agricultor?

8. Quais os EPI's que você utiliza?

9. Na sua opinião, quais os cuidados realizados pelos trabalhadores para proteger a tanto a sua saúde como a da comunidade? 
ANEXOS 
ANEXO A - Parecer do Comitê de Ética

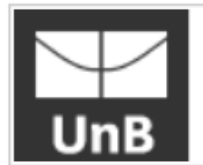

\section{FACULDADE DE CIÊNCIAS DA \\ SAÚDE DA UNIVERSIDADE DE BRASÍLIA - CEP/FS-UNB}

\section{PARECER CONSUBSTANCIADO DO CEP}

\section{DADOS DO PROJETO DE PESQUISA}

Titulo da Pesquisa: AGRICULTURA E SAÚDE: UMA ABORDAGEM SOBRE O PERFIL DE SAÚDE DO AGRICULTOR DA ZONA RURAL DE BRAZLÂNDIA

Pesquisador: MARCELA FONSECA JONAS

Área Temática:

Versão: 2

CAAE: 36742014.3 .0000 .0030

Instituição Proponente:PROGRAMA DE PÓS-GRADUAÇÃO EM CIÊNCIAS E TECNOLOGIAS EM

Patrocinador Principal: Financiamento Próprio

DADOS DO PARECER

Número do Parecer: 943.423

Data da Relatoria: 03/02/2015

Apresentação do Projeto:

Parecer Consubstanciado PENDÊNCIAS

AGRICULTURA E SAÚDE: UMA ABORDAGEM SOBRE O PERFIL DO

AGRICULTOR DA ZONA RURAL DE BRAZLÂNDIA

Projeto de mestrado do curso de pós-graduação em ciências e tecnologia da Universidade de Brasília.

ORIENTADORA: PROFa. DR. MARIA HOSANA CONCEIÇÃO

CO-ORIENTADORA: PROFa. DR. ALDIRA G. DUARTE DOMINGUEZ

Considerações sobre os Termos de apresentação obrigatória:

Documentos analisados:

1. Parecer consubstanciado do CEP.pdf.15/12/14

2. Carta pendências.pdf.17/12/14

3. Informações básicas do projeto.17/12/14

Recomendações:

Não se aplica.

Conclusões ou Pendências e Lista de Inadequações:

Análise das respostas às pendências apontadas no Parecer No. 911.653 de 09/12/2014

- O cronograma de atividades foi adequado. PENDÊNCIA ATENDIDA.

O projeto está de acordo com a Resolução CNS 466/2012 e suas completares.

Situação do Parecer:

Aprovado

Necessita Apreciação da CONEP:

Não

Considerações Finais a critério do CEP:

Em acordo com a Resolução 466/12 CNS, itens X.1.- 3.b. e XI.2.d, os pesquisadores responsáveis deverão apresentar relatórios parcial semestral e final do projeto de pesquisa, contados a partir da data de aprovação do protocolo de pesquisa.

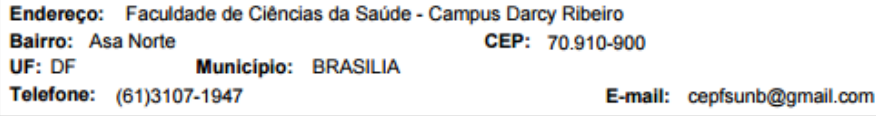


ANEXO B - Publicação

\title{
O trabalho agrícola e a saúde dos agricultores da zona rural de Brazlândia, Distrito Federal, Brasil
}

Agricultural work and health of farmers from the rural area of Brazlândia, Federal District, Brazil

El trabajo agrícola y la salud de los agricultores de la zona rural de Brazlândia, Distrito Federal, Brasil

\author{
Marcela Fonseca Jonas ${ }^{1}$ \\ Maria Hosana Conceição ${ }^{2}$ \\ Aldira Guimarães Duarte Domínguez ${ }^{2}$
}

\section{Resumo}

Este trabalho buscou investigar os efeitos do contato contínuo com agrotóxicos na saúde dos agricultores familiares. Trata-se de estudo quali-quantitativo, realizado com 10 agricultores em contato com agrotóxicos na Chapadinha, zona rural de Brazlândia-DF, por meio da entrevista semiestruturada e dados secundários de amostras sanguíneas. Coleta de dados realizou-se entre março de 2014 e março de 2015. Os depoimentos foram analisados com base na técnica de análise temática de conteúdo, e as amostras sanguíneas pelo método cinético, após a aprovação do projeto de pesquisa pelo Comitê de Ética da Faculdade de Ciências da Saúde da Universidade de Brasília. Identificaram-se duas categorias: "a proteção individual e coletiva realizada pelos trabalhadores rurais" e "o uso do agrotóxico e seus efeitos na saúde”. Os trabalhadores da região apresentam sintomas específicos da intoxicação por agrotóxicos, porém os exames de colinesterase sérica apresentam-se dentro da normalidade. Isso demonstra a importância do exame clínico por um profissional da saúde habilitado.

Descritores: Atenção à Saúde, agricultores, Inibidores da Colinesterase. 


\begin{abstract}
This paper aimed to investigate the effects of continuous contact with pesticides on the health of family farmers. This is a qualitative-quantitative study with 10 farmers exposed to pesticides in Chapadinha, rural area of Brazlândia, Federal District, Brazil, who were evaluated using a semi-structured interview and secondary blood sample data. Data collection occurred from March 2014 to March 2015. The interviews were assessed by means of thematic content analysis and blood samples were assessed by the kinetic method using butyrylthiocholine, after the research project was approved by the Research Ethics Committee of the School of Health Sciences of Universidade de Brasília. Two thematic categories were identified: "individual and collective protection measures taken by rural workers" and "use of pesticides and its health effects". The workers from the study area had symptoms specific of pesticide poisoning, but serum cholinesterase levels were normal. This discrepancy shows the importance of clinical examination by a qualified healthcare professional.
\end{abstract}

\title{
Introdução
}

A população no Distrito Federal, assim como em todo o mundo, aumentou nas últimas décadas e, consequentemente o consumo de alimentos ${ }^{1}$. Para atender essa demanda populacional, a agricultura começou a produzir cada vez mais alimento, considerando o uso de novas tecnologias. Pode-se citar como exemplo as práticas que auxiliam na proteção contra ações de pragas e doenças de insetos e ervas daninhas, tal como a utilização do agrotóxico ${ }^{2,3}$.

Apesar dos benefícios proporcionados por esses compostos; eles, também, são responsáveis por riscos causados à saúde humana e ao ambiente ${ }^{4}$. Os agrotóxicos podem causar intoxicações ao homem, acumulo de resíduos nos alimentos e no ambiente ou contribuírem para o desenvolvimento de pragas resistentes, se usado de forma inadequada ou se os usuários não estiverem cientes desses problemas potenciais ${ }^{5}$.

Existem vários fatores que levam à intoxicação dos agricultores e trabalhadores rurais, tais como o manuseio inadequado do produto químico, falta de conhecimento sobre o produto e seus efeitos, o uso indevido ou a falta de uso dos Equipamentos de Proteção Individual (EPIs), dentre outros ${ }^{6}$. Esses são alguns dos motivos que levam os governantes juntamente com os estudiosos procuram entender a dimensão do problema que a classe trabalhadora do campo vivencia, visando elaborar planos e estratégias de intervenção na saúde da população rural. 
Buscando a melhoria na qualidade de vida dos agricultores, além de contribuir para o processo de construção de estratégias de intervenção no meio rural, estudos são conduzidos com populações rurais no Brasil e no mundo ${ }^{7,8}$. No entanto, o estudo mais detalhado sobre a percepção dos trabalhadores rurais da região da Chapadinha, Zona Rural de Brazlândia Distrito Federal, quanto ao uso do agrotóxico, ainda não tinha sido realizado. Deste modo, justificou-se a necessidade de compreender os riscos e os agravos causados à saúde dos trabalhadores e moradores da Chapadinha, Zona Rural de Brazlândia - DF pelo contato com os agrotóxicos utilizados na agricultura.

A partir do conhecimento da opinião dos agricultores familiares e moradores da Chapadinha - DF, será possível desenvolver e implementar estratégias de enfrentamento dessa realidade. Além disso, será possível também propor a oferta de um serviço de saúde com qualidade direcionada a essa população supostamente exposta aos agrotóxicos. Por outro lado, este estudo disponibilizará informações que possam contribuir para a redução de risco a saúde do trabalhador e consequentemente o bem-estar das suas famílias.

Sobretudo, neste trabalho, foram abordadas questões específicas e correlatas sobre a saúde dos agricultores, o uso dos EPI's, assim como aspectos relacionados ao manuseio dos agrotóxicos.

Diante dessa dimensão, o objetivo principal deste trabalho foi investigar os efeitos na saúde dos agricultores familiares e moradores da Chapadinha, Zona Rural de Brazlândia - DF consequentes do contato contínuo com o agrotóxico; esperando, compreender e discutir melhor os efeitos que o manejo dos agrotóxicos possa causar a saúde dos trabalhadores a fim de contribuir para a elaboração de estratégias que auxiliem na sua qualidade de vida.

\section{Materiais e Métodos}

Estudo quali-quantitativo de natureza transversal, desenvolvido na Zona Rural de Brazlândia - região da Chapadinha e cuja duração foi de doze meses, de março de 2014 à março de 2015, durante os quais foram desenvolvidas etapas do projeto, como a aplicação das entrevistas e realização das análises. Trata-se de uma região de referência dentro do Distrito Federal, onde o trabalho agrário é intenso, sendo o celeiro de abastecimento do entorno. Vale salientar que a região possui muitos registros de consumo de agrotóxicos, o que instigou à busca de mais informações e questionamentos no que se refere ao uso do agrotóxico pelos agricultores familiares/moradores e seus efeitos na saúde da população da área estudada ${ }^{7}$. 
A amostra foi constituída, desde a perspectiva da pesquisa qualitativa, por dez entrevistados, entre agricultores familiares e moradores que têm contato direto ou indireto com os agrotóxicos, sendo esta uma condição elencada como critério de inclusão estabelecido para uma melhor homogeneização do grupo amostral. Foram excluídos, aqueles participantes que se recusaram a assinar, previamente, o Termo de Consentimento Livre e Esclarecido (TCLE) e não concordem em participar da pesquisa.

A determinação do número de participantes está relacionada com o critério de saturação de dados, a qual ocorre quando a coleta de dados para de produzir novas informações ou essas são redundantes.

A coleta de dados, para o estudo qualitativo, foi realizada por meio de entrevista semiestruturada individualizada, as quais foram gravadas e transcritas mediante autorização prévia dos participantes. Foram formuladas duas questões norteadoras que serviram para a apreensão da realidade, a saber: $\mathrm{O}$ que você pensa sobre o uso do agrotóxico nas plantações onde trabalha e a relação com sua saúde? e Na sua opinião, quais os cuidados realizados pelos trabalhadores para proteger a tanto a sua saúde como a da comunidade?

Os dados empíricos produzidos neste estudo seguiram as etapas preconizadas pelo método qualitativo de análise de conteúdo na categoria de análise temática ${ }^{9}$. A condução deste tipo de análise envolve passos sistemáticos, sendo eles: a codificação dos dados; a categorização dos dados e a interação dos núcleos temáticos. Dessa forma, a análise teve início com a leitura e re-leitura das entrevistas, buscando a identificação da percepção do agrotóxico, bem como os cuidados com a saúde do trabalhador e comunidade. Assim, foi possível identificar as categorias e integrá-las no núcleo temático.

Por se tratar de uma investigação com seres humanos, o projeto foi submetido ao Comitê de Ética em Pesquisa com Seres Humanos da Faculdade de Ciências da Saúde da UnB sob o Parecer número 943.423 e CAAE 36742014.3.0000.0030 (ANEXO A), como preconiza a Resolução 466/2012 do Conselho Nacional de Saúde. Os participantes assinaram o Termo de Consentimento Livre e Esclarecido, em duas vias, ficando com uma delas e a outra sob a posse do pesquisador responsável. Com o propósito de atender princípios éticos, os sujeitos envolvidos na pesquisa foram informados e esclarecidos sobre os seus objetivos. $\mathrm{Na}$ apresentação dos resultados, utilizaram-se as letras "TR" para identificar o trabalhador rural e/ou morador, seguido dos números arábicos que representam a sequência da realização das entrevistas. 


\section{Resultados e Discussão}

Dados socioeconômicos revelaram que os agricultores familiares e moradores da Chapadinha, Zona Rural de Brazlândia-DF participantes do estudo possuem faixa etária variável entre 26 e 63 anos, sendo seis do sexo masculino e quatro do sexo feminino. A maioria dos participantes é casada, apresentando renda familiar entre um e quatro salários mínimos e trabalham na agricultura há mais de oito anos. Dentre os dez participantes, sete säo não fumantes e todos utilizam agrotóxicos na sua plantação. Em relação à escolaridade, oito possuem o ensino fundamental incompleto, e dois com ensino médio completo.

$\mathrm{Na}$ Chapadinha, entre os 12 produtos comerciais diferentes utilizados pelos agricultores, metade classifica-se entre altamente e extremamente tóxico para a saúde humana de acordo com a Tabela 2. Sendo assim, os agricultores podem estar sob-risco de exposição química mesmo que apenas um desses produtos seja utilizado na agricultura em alguma das propriedades visitadas. Entretanto, a situação encontrada é ainda mais grave, visto que todos os agricultores que utilizam esses produtos concomitante com outros agrotóxicos. A tabela também ilustra os principais agrotóxicos utilizados pelos agricultores do estudo.

A partir da análise detalhada dos discursos dos participantes definiu-se a Unidade Temática Central ou Núcleo de Sentido, intitulando-se “A exposição e proteção dos trabalhadores rurais aos agrotóxicos".

Para possibilitar uma discussão mais aprofundada acerca do referido núcleo, mediante a técnica de Análise de Conteúdo na Modalidade Temática, emergiram três categorias permitindo assim um melhor direcionamento do estudo.

As percepções dos participantes foram agrupadas quanto às implicações por eles sofridas em relação à exposição e proteção aos agrotóxicos, constituindo as categorias: “ $A$ proteção individual e coletiva realizada pelos trabalhadores rurais" $e$ "o uso do agrotóxico e seus efeitos na saúde”, as quais serão apresentadas e discutidas a seguir.

\section{- Proteção individual e coletiva dos agrotóxicos: ações consumadas pelos trabalhadores rurais da Chapadinha}

A proteção individual e coletiva dos agrotóxicos no processo de produção é algo perceptível também em outros estudos ${ }^{10,11}$. As medidas de proteção individual são todas as 
atitudes relacionadas às práticas de trabalho do agricultor, as medidas higiênicas, e principalmente, o uso de equipamentos e vestimentas de proteção ${ }^{12,13}$.

Entretanto, os participantes do estudo associam a proteção individual somente ao uso do EPI, apenas um entrevistado relacionou a proteção individual ao cuidado com a direção do vento. Nas falas a seguir também percebe o uso fragmentado dos equipamentos, visto que eles não utilizam o conjunto completo, que seria o ideal para ter a proteção total.

"A minha, os meus cuidados, praticamente eu não cuido de mim, eu uso calça, uso botas, e procuro estar sempre do lado do vento" (TRI).

"Eu uso a Bota, calça, camisa, avental, luvas, mascara [...] quando não está ventando a gente não usa a viseira que embaça" (TR6).

"A máscara, ai tem aquela viseira, e a camisa de mangas compridas, a calça com a parte que não deixa passar o veneno [...]" (TR7).

"A gente usa as roupas que tem aquela EPI [...] e ainda usa máscara, ainda usa um pano também para cobrir o rosto, a camisa, luvas, botina" (TR10).

Os EPI's, na maioria das vezes, não são desejados pelos os agricultores familiares da Chapadinha, Zona Rural de Brazlândia - DF, pois os entrevistados mencionam o incômodo causado por estes, tais como falta de ar e calor intenso, além de alguns atrapalharem suas atividades laborais.

"[...] aquilo incomoda, demora você... Eu trabalhava numa chácara que o rapaz lá forneceu para a gente bota, a roupa, a máscara, mas o jeito que a gente trabalhava não aguentava, abafa aquele calor, a bota sua, se bota a máscara, a máscara, devido ao movimento que você faz cansa, começa a cansar e a respiração não fica solta, então prende a respiração" (TRI).

"[...] é um pouco desconfortável, mas a gente tem que usar, é quente, como eu falei, embaça, mas a gente está aos poucos se conscientizando, a gente passou muito tempo sem usar [...] a gente vai se conscientizando, ele é essencial" (TR4).

"[...] mas é porque é muito ruim ficar sem respirar direito $e$ morrendo de calor com a roupa” (TR9).

Um estudo desenvolvido no Município de Pelotas (RS) apresenta dados semelhantes. Os fumicultores do estudo de Silva et al. ${ }^{14}$, relatam a utilização de algum tipo de EPI, mas não da maneira adequada para proteção ideal, pois alguns dos EPI's são considerados desconfortáveis. De acordo com Oliveira e Machado Neto ${ }^{15}$, muitos agricultores realizam a 
pulverização, principalmente nos meses mais quentes do ano, sem os materiais necessários, visto que o mal-estar e o desconforto desencorajam os trabalhadores rurais.

Uma pesquisa desenvolvida por Almeida et al. ${ }^{16}$ com fumicultores demonstrou a rara utilização dos equipamentos de proteção recomendados, diante disso a pesquisadora questiona

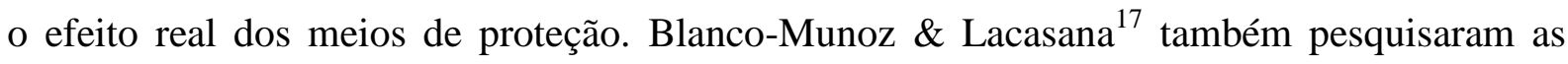
restrições laborais e dificuldades ligadas à utilização dos EPI's, e observaram que os equipamentos estão inadequados às condições ergonômicas e ambientais, esses dados corroboram como as informações apresentadas no estudo em Chapadinha, Zona Rural de Brazlândia - DF.

A divergência quanto ao uso do EPI pelos trabalhadores rurais é bem perceptível neste estudo, visto que um dos entrevistados deixa explícito que o EPI deve ser utilizado em todas as atividades que envolvem contato com o agrotóxico, no entanto outros agricultores declaram não utilizar os EPI's em algumas atividades como o preparo da calda de pulverização, alegando que os EPI's dificultam o manuseio retardando o preparo do produto $\mathrm{e}$ consequentemente atrasando o processo de produção.

"[...] em tudo que a gente for mexer que tiver veneno tem que estar com o equipamento de segurança, pra fazer a calda, pra pulverizar, pra tudo" (TR3).

"[...] o único cuidado que tenho é que eu não fico muito em cima, porque o cheiro é forte. [...] uso a minha roupa, calça e camisa, e às vezes a máscara e só" (TR4).

"[...] na hora da calda não tenho muito cuidado com isso não [...] Às vezes eu fico sem as luvas, sem as luvas, porque às vezes a gente vem com pressa e as luvas às vezes atrapalham um pouco para manusear os frascos" (TR7).

A via dérmica corresponde a mais de $99 \%$ da exposição total aos agrotóxicos, se destacando como a maior via de contaminação, logo em seguida está a via inalatória ${ }^{18}$. Diante desses dados, o uso do EPI é fundamental, sendo uma medida importante durante a preparação da calda, pois serve de barreira para a entrada da substância no organismo, colaborando para evitar contaminações e consequentes intoxicações ${ }^{19}$. Algumas medidas higiênicas foram observadas nas falas dos entrevistados, tais como a limpeza dos EPI's e o banho após o término do manuseio. A lavagem da roupa utilizada para o manejo do agrotóxico e a lavam da casa visando a manutenção da saúde dos residentes geralmente são 
realizadas por mulheres; no entanto eles não fazem a correlação dessas atitudes aos cuidados individuais.

"A minha roupa é lavada em casa mesmo, no tanque, na máquina [...] depois vou pro banheiro, pra banhar e tirar toda sujeira [...]" (TR1).

"A roupa nossa, a bota, luva avental, essas coisas... a gente lava aqui fora, nós lava ela em água corrente, a água correu, o veneno que está na roupa [...] tem vez que uso só a máscara, quando minha garganta coça. [...] E a minha roupa eu levo pra casa e minha mãe lava. [...] Ela colocar só a minha roupa na máquina, coloca sabão e muita água, pra diminuir o agrotóxico” (TR8).

"Eu gosto de lavar e esfregar á casa [...] fico de chinelo, mas eu tenho a bota" (TR9).

Os estudos de Júnior et al. ${ }^{20}$ apresentam resultados parecidos com o deste estudo, já que os autores também apontam as mulheres como responsáveis pela lavagem das roupas contaminadas, além disso a pesquisa informa que as mulheres tem dificuldade de visualizar os riscos que enfrentam ao desenvolver esta atividade, contribuindo assim para sua exposição somatória.

As medidas de higiene devem seguir alguns critérios, tais como lavar separadamente das roupas comuns, logo após o dia de trabalho; utilizar luvas e avental para proceder a higienização, aconselha-se realizar a pré-lavagem antes da lavagem propriamente dita, pois é o método mais efetivo para remover a contaminação da roupa ${ }^{21}$.

A lavagem da roupa deve ser feita apenas com água e sabão e será suficiente para diluir e neutralizar os resíduos do produto depois que acabar a lavagem da roupa. É necessário limpar o tanque ou a máquina de lavar para certificar-se de que eventuais resíduos sejam removidos ${ }^{21}$.

Objetivando proteger a saúde da comunidade em geral, os agricultores do estudo mencionam atitudes cuidadosas como a leitura do rótulo, pois este é a principal forma de comunicação entre o fabricante e os usuários. No rótulo contém informações sobre as culturas específicas para o agrotóxico; as dosagens para cada situação; a época em que o agrotóxico deve ser usado e o período de carência, ou seja, o intervalo de tempo, em dias, que deve ser observado entre a aplicação do agrotóxico e a colheita do produto agrícola ${ }^{22}$.

"[...] a gente tem que respeitar o prazo do veneno, do agrotóxico, e se é três dias, vamos colocar três dias para poder colher, e muitas vezes 
o produtor não respeita, e você vai fazer uma pesquisa está lá o produto com agrotóxico, porque faltou respeitar o prazo" (TR2).

“[...] cuidado pra pulverizar na estação certa [...] tem produto que é pra aplicar só no início da plantação, outros só podem quando tem uma situação mais grave, essas coisas a gente deve seguir, pra não prejudicar os outros animais [...]" (TR5).

"[...] sempre a dosagem aquilo que pede na bula, pra não ficar forte... Quando eu fiz o curso da EMATER, eles mostraram como o ambiente fica contaminado se a gente não tiver cuidado... [...] não colocar o veneno que é de uma planta em outra [...], por exemplo, tem vez que sobra o veneno da abobrinha e o produtor pega e coloca no morango, pra não estragar" (TR7).

Respeitar o período de carência significa colher produtos agrícola no final da safra livre de resíduos do agrotóxico em níveis acima do limite máximo permitido pelo Ministério da Saúde; além disso, é ilegal comercializar alimentos acima do limite máximo fixado por aquele Ministério $^{23}$.

O estudo de Vinha et al. $^{24}$ proporciona resultados indicando alto percentual de irregularidades no uso de agrotóxicos, pois foi constatada a presença de resíduos de agrotóxicos proibidos ou acima dos limites permitidos em frutas e hortaliças, deste modo os pesquisadores apontam a necessidade da sensibilização dos agricultores para importância de respeitar o período de carência dos agrotóxicos.

$\mathrm{O}$ armazenamento e o descarte das embalagens de agrotóxicos vazias também foram itens apresentados pelos agricultores quando questionados sobre os cuidados de proteção à saúde da comunidade. No entanto, as falas revelam sentimento de dúvidas quanto ao tema e diante da situação, foi observado que as ações nem sempre são realizadas de forma correta.

Verificou-se que a maior parte dos agricultores realiza a devolução das embalagens de agrotóxicos vazias, porém uma minoria devolve as embalagens sem os devidos cuidados, pois é perceptível a ausência da tríplice lavagem em algumas falas.

"Fazer o descarte certo das embalagens [...] As embalagens eu costumo [...] eu entreguei para o pessoal que veio recolher [...] está tudo guardada lá dentro de sacola [...] longe de casa. [...] lavo com água [...] só uma vez" (TR1).

"[...] a gente junta e devolve lá em Brazlândia [...] eu guardo no quarto ali, longe da casa. [...] a gente só joga água dentro e balança, passa uma água para tirar o forte e depois fura" (TR4). 
"[...] as embalagens têm um postinho perto de Brazlândia que a gente devolve, junta ali mais ou menos seis meses, um ano e aí vai lá e devolve, na entrada de Brazlândia. [...] A gente lava com água, só com água, três vezes... e fura o fundo" (TR6).

"[...] coloca dentro de um saco e joga lá no meio do mato [...]" (TR9).

Um estudo que analisou a tendência da devolução de embalagens vazias de agrotóxicos no estado do Paraná, observou um crescente aumento no fluxo de devolução de embalagens vazias de agrotóxicos, depois de que o governo desenvolveu campanhas educativas utilizando a mídia como ferramenta de divulgação. O estudo aponta também que o agricultor transforma-se em um produtor conscientizado ecologicamente ${ }^{25}$.

A lei que determina as responsabilidades compartilhadas entre agricultores, canais de distribuição, cooperativas, industrias e poder público quanto ao destino final das embalagens vazias de agrotóxicos é a Lei $\mathrm{n}^{\mathrm{o}} 7.802$, de 11 de julho de 1989 . Segundo Abreu \& Alonzo ${ }^{21}$ a devolução das embalagens vazias dos produtos devem ser realizadas de acordo com as instruções previstas nas bulas, no prazo de até um ano, contado da data de compra.

As embalagens, antes de serem devolvidas, devem passar pelo processo denominado de tríplice lavagem, a qual consiste no esvaziamento completo da embalagem, na adição de água limpa até $1 / 4$ do volume do recipiente e agita-lo; logo em seguida deve despejar a água de lavagem no tanque do pulverizador; essa operação deve ser feita 3 vezes, e pra finalizar deve perfurar o fundo, inutilizando a embalagem ${ }^{26}$.

\section{- Efeitos na saúde do agricultor familiar e morador da Chapadinha-DF}

O avanço científico e tecnológico empregado como o processo de desenvolvimento econômico, impulsionado pela globalização mundial tem favorecido vários setores da economia, dentre eles o setor do agronegócio. O Brasil ocupa desde 2008 o primeiro lugar no mundo em consumo de insumos agropecuários, graças ao desenvolvimento das indústrias químicas, com a utilização de agrotóxicos e fertilizantes ${ }^{27}$.

Desde 2004 o consumo de agrotóxico aumentou significativamente no Brasil, diante disso, o mercado brasileiro de agrotóxicos cresceu 190\%, enquanto o mercado mundial de agrotóxicos cresceu 93\%. Desde 2008, o Brasil é o maior consumidor dessas substâncias no mundo ${ }^{28,29}$. 
Nenhum grupo populacional brasileiro é tão vulnerável a esses produtos quanto os trabalhadores rurais, realidade essa que é um grande desafio para o setor da saúde que dedicase à assistência das populações rurais ${ }^{30}$.

Pesticide Action Network (PAN) ${ }^{31}$ informa que a o número de intoxicações por agrotóxicos em todo o mundo não pode ser estimado, visto que a subnotificação é alta. Apesar disso existem muitos estudos nas várias regiões do Brasil e do mundo que apresentam altas taxas de intoxicação por agrotóxicos ${ }^{32,33,34}$.

No Distrito Federal, durante o período de julho de 2004 a dezembro de 2007, foram registrados 1.085 casos de intoxicações ao Centro de Informação e Assistência Toxicológica do Distrito Federal, Brasil (CIAT-DF), esses registros foram principalmente nos hospitais da zuna rural $^{35}$.

A sintomatologia da intoxicação por agrotóxico pode ocorrer nas modalidades de intoxicação aguda leve, moderada ou grave; e na forma de intoxicação crônica ${ }^{36}$. O tipo da intoxicação (leve, moderada ou aguda) vai depender da quantidade de agrotóxico absorvido, do tempo de absorção, da toxicidade do produto e do tempo de exposição ao produto. A sintomatologia manifesta-se através de um conjunto de sinais e sintomas, que se apresentam de forma súbita, alguns minutos ou algumas horas após a exposição excessiva a um agrotóxico.

A intoxicação crônica é caracterizada pelos efeitos danosos sobre a saúde humana, incluindo a acumulação de danos genéticos, que surgem no decorrer de repetidas exposições ao tóxico durante longos períodos. Nestas condições os quadros clínicos são indefinidos, confusos e muitas vezes irreversíveis e o diagnóstico é difícil de ser estabelecido e associado ao agrotóxico. A intoxicação crônica manifesta-se através de inúmeras patologias, que atingem vários órgãos e sistemas, com destaque para os problemas imunológicos, hematológicos, psicológicos, neurológicos, malformações congênitas e tumores ${ }^{36,37,38}$.

No presente estudo os trabalhadores entrevistados relataram apresentar sintomas compatíveis com intoxicação por agrotóxicos após o manuseio com algum objeto contaminado ou o próprio composto químico.

"Eu passei a sentir alergia, ficava espirrando que dentro do nariz incha [...] dá muito pigarro, esse Decis ele dá muito isso, o Polytrin também, o Decis dá mais, tem outro que tem o mesmo cheiro que ele também dá. [...]eu ganhei uns herbicidas do meu pai e eu fui com a mão, eu passei assim mais ou menos uns dois dias com a mão assim, queimando e coçando" (TRl). 
"[...] quando lavei a roupa dele na mão, essa parte aqui da minha mão e essa aqui do braço ficou vermelho” (TR3).

"[...] diz que toda vez que entro com a roupa da pulverização ela começa a arder o olho [...]” (TR6).

"[...] quando o camarada bate eu já começo a espirrar, fechar as portas porque eu passo mal com isso. [...] eu sou alérgica [...] é veneno, é tudo [...]" (TR9).

"[...] muita vezes eu sinto dor no estômago, depois da aplicação [...] Ardência no olho, fico tonto, minha garganta fica seca, ardendo" (TR10).

De acordo com o Ministério da Saúde o quadro clínico da intoxicação aguda leve é caracterizado por cefaleia, irritação cutaneomucosa, dermatite de contato irritativa ou por hipersensibilidade, náusea e discreta tontura ${ }^{39}$. Já a intoxicação aguda moderada apresenta a cefaleia intensa, náusea, vômitos, cólicas abdominais, tontura mais intensa, fraqueza generalizada, parestesias, dispneia, salivação e sudorese aumentadas. Na intoxicação aguda grave os sintomas são mais bem definidos, como a miose, hipotensão, arritmias cardíacas, insuficiência respiratória, edema agudo de pulmão, pneumonite química, convulsões, alterações da consciência, choque, coma, podendo evoluir para óbito.

Estudo realizado na comunidade rural de Campo Mourão, Paraná, relatou que quando os agrotóxicos são aplicados nas lavouras através da pulverização, 54\% dos trabalhadores apresentam sintomas, como dor de cabeça, lacrimejamento, tontura e problemas dermatológicos $^{40}$. Outro estudo aponta dados semelhantes ao informar que mais da metade dos entrevistados notou algum problema de saúde relacionado à pulverização dos agrotóxicos, tendo como sintomas agudos mais frequentes os problemas estomacais e dores de cabeça ${ }^{37,41}$.

Todos os agricultores e morados da Chapadinha, Zona Rural de Brazlândia - DF, responderam nunca terem procurado assistência médica devido a problemas relacionados ao agrotóxico. No entanto, todos responderam positivamente ao serem questionados sobre hospitalizações ou internações; referiram a busca pelo serviço de saúde em situações como tosse persistente, dor de cabeça intensa e problemas gástricos.

"Quando eu tava com uma tosse, essa tosse não passava de jeito nenhum, pensava que era gripe, daquelas forte, mas o médico disse que era tosse alérgica" (TR4).

"Uma vez, há muito tempo eu procurei o médico, porque eu senti dor de cabeça, ai fu no medico, ai deu enxaqueca” (TR6). 
"Eu já fui no postinho porque sentia muita dor no estômago [...] acabei indo no médico que mexe com isso e ele falou em gastrite[...] tomo o remédio, mas mesmo assim, ainda sinto uma coisinha aqui outra ali" (TR10).

Fica evidente neste estudo que tanto os agricultores familiares como os trabalhadores da saúde não fazem uma relação direta entres os sintomas apresentados e o contato contínuo com os agrotóxicos. A pesquisa realizada na comunidade ribeirinha do Rio dos Sinos destaca que $93 \%$ não relacionam seus problemas de saúde à sua exposição ao agrotóxico, além de relatar não apresentar problema de saúde decorrente do uso de defensivos ${ }^{42}$.

Um dado relevante no presente estudo foram relatos de uma participante que confirma ter recebido um diagnóstico de depressão e fibromialgia. A entrevistada demonstra um sentimento de inutilidade, visto que a predominância dos problemas referidos geram incapacidade laborativa.

"[...] o médico me disse que é depressão. [...] a fibromialgia é um sacrifício, doe muito, já fiz de tudo. [...] é difícil eu dormir de noite, aí todo dia eu fico cansada e não dá vontade de você fazer nada, aí quando eu tô ruim, meu marido que faz as coisas dentro de casa [...] já fiquei no hospital por causa dessa depressão" (TR9).

Estudos relatam associações positivas entre pesticidas e depressão, mas poucos estudos foram prospectivos ou apresentaram resultados para as mulheres separadamente ${ }^{39}$. Um estudo em Iowa e Carolina do Norte destaca que a depressão incidente em mulheres é relacionada à intoxicação por agrotóxicos ${ }^{43}$.

A pesquisa realizada com o agricultor familiar e morador da Chapadinha, Zona Rural de Brazlândia - DF, demonstrou que os participantes do estudo apresentaram vários sinais e sintomas característicos da intoxicação pelo contato com o agrotóxico.

\section{Conclusões}

No cotidiano dos agricultores familiares, comumente, é percebido o uso e consequentemente o contato com o agrotóxico. Quando utilizado indiscriminadamente, evidencia-se significativa desorganização na dinâmica natural do meio ambiente, visto que a contaminação deste afeta diretamente os seres vivos não alvos do produto. Além disso, a intoxicação do trabalhador rural acomete a estabilidade do sistema de produção.

Percebe-se entre os agricultores da Chapadinha a necessidade de mais informações referentes ao uso correto do agrotóxico nas lavouras, também é importante o reajuste nas ações desenvolvidas para proteção da sua saúde e da comunidade, sendo necessário buscar 
estratégias para evitar possíveis contaminações e intoxicações, principalmente no que refere aos EPI's, pois grande parte não faz uso da roupa completa durante o manejo do produto químico.

Além disso, foi discutido o adoecimento desses trabalhadores com sintomas específicos da intoxicação por agrotóxicos, como mal-estar, cefaleia e dores gástricas, além da depressão presente entre os agricultores da Chapadinha, demonstrando a importância do exame clínico por um profissional da saúde habilitado.

Ressalta-se, contudo, como fator relevante para a prevenção das intoxicações a sensibilização dos agricultores quanto à maneira correta e segura de uso destes produtos. É fundamental, portanto, o envolvimento de profissionais de saúde, como o enfermeiro, para atuar nesse processo de conscientização, com o intuito de prevenir e promover a saúde desse trabalhador.

Com os estudos científicos sobre o assunto publicados, é possível desenvolver ações para preservar a saúde, combater as intoxicações e estimular a melhoria da qualidade de vida dos agricultores, além de divulgar informações de interesse para a saúde do trabalhador rural.

\section{Referências}

1. Ribeiro EP, de Lima MS, Nóbrega RS, Mota Filho FO. Segurança e saúde do aplicador de agrotóxicos: agricultores do município de São Joaquim do Monte-PE. Rev Geo (Recife) 2014; 31:39-57.

2. Seck PA, Diagne A, Mohanty S, Wopereis MC. Crops that feed the world 7: rice. Food Sec 2012; 4:7-24.

3. Köhler HR, Triebskorn R. Wildlife ecotoxicology of pesticides: can we track effects to the population level and beyond? Science 2013; 341:759-65.

4. Gunnell D, Eddleston M, Phillips MR, Konradsen F. The global distribution of fatal pesticide self-poisoning: systematic review. BMC Public Health 2007; 7:357.

5. Berti AP, Düsman E; Soares LC. Efeitos da contaminação do ambiente aquático por óleos e agrotóxicos. SaBios: Rev Saude e Biol 2009; 4:45-51.

6. Costa GB, Moreno EC, de Souza Trindade G; Studies Group in Bovine Vaccinia. Neutralizing antibodies associated with exposure factors to Orthopoxvirus in laboratory workers. Vaccine 2013; 31:4706-9.

7. Gomes KB, Oliveira GH, Carvalho JP, Cavalcante DF, Villa-Real ME. Diagnóstico da cadeia produtiva do morango dos agricultores familiares do Distrito Federal. Rev EIXO 2013; 2:3-12. 
8. Oliveira FD, Santos NR. Principais culturas e ações antrópicas no Rio Mamanguape no município de Lagoa Seca-PB: percepção dos agricultores ribeirinhos. Rev Scire 2013; 1:1-8.

9. Bardin, L. Análise de conteúdo. São Paulo: Edições 70; 2011.

10. Burkett DA, Cope SE, Strickman DA, White GB. The Deployed Warfighter Protection (DWFP) Research Program: developing new public health pesticides, application technologies, and repellent systems. J Integ Pest Mngmt 2013; 4:A1-A7.

11. Lesmes-Fabian C, Binder CR. Pesticide flow analysis to assess human exposure in greenhouse flower production in Colombia. Int J Environ Res Public Health 2013; 10:11681185 .

12. Kelley MA, Flocks JD, Economos J, McCauley LA. Female farmworkers' health during pregnancy: health care providers' perspectives. Workplace Health Saf 2013; 61:308-13.

13. Brown AE, Ramsay C, Foss C. Pairing epidemiological research results with a practical message to improve pesticide applicators' personal safety practices. J Pestic Saf Educ 2012; $14: 23-32$.

14. Silva JB, Xavier DS, Barboza MC, Amestoy SC, Trindade LL, Silva JR. Fumicultores da zona rural de Pelotas (RS), no Brasil: exposição ocupacional e a utilização de equipamentos de proteção individual (EPI). Saúde em Debate 2013; 37:347-53.

15. Oliveira ML, Machado Neto JG. Segurança na aplicação de agrotóxicos -em cultura de batata em regiões montahosas. Rev Bras Saude Ocup 2005; 30:15-25.

16. Almeida EA, Zimmermann MH, Gonçalves CS, Grden CR, Maciel MA, Bail L, et al. Agrotóxicos e o risco à saúde entre fumicultores. Publ. UEPG Ci Biol Saude 2011; 17:133-9.

17. Blanco-Muñoz J, Lacasaña M. Practices in pesticide handling and the use of personal protective equipment in Mexican agricultural workers. J Agromedicine 2011; 16:117-26.

18. Botti MV. Controle de Aedes aegypti: período residual de temefós na água em recipientes de plástico, vidro e borracha, ação larvicida residual em recipientes de borracha e segurança das condições de trabalho na nebulização de malathion [tese de doutorado]. Jaboticabal: Faculdade de Ciências Agrárias e Veterinárias, Universidade Estadual Paulista Júlio de Mesquita Filho; 2010.

19. Veiga MM, Duarte FJ, Meirelles LA, Garrígou A, Baldi I. A contaminação por agrotóxicos e os Equipamentos de Proteção Individual (EPIs). Rev Bras Saude Ocup 2007; 32:57-68.

20. Fontoura Jr EE, Souza KR, Renovato RD, Sales CM. Relações de saúde e trabalho em assentamento rural do MST na região de fronteira Brasil-Paraguai. Trab Educ Saude 2011; 9:379-97.

21. de Abreu PH, Alonzo HG. [Rural work and health risks: a review into de "safe use" of pesticides in Brazil]. Cien Saude Colet 2014; 19:4197-208. 
22. Uyeda J, Sugano J, Chou MY, Fukuda S, Uchida J, Melzer M, et al. Major Basil Pests in Hawai' 1 : Three Economically Important Basil Pests as of 2012. Plant Disease 2012; P92:1-4.

23. Sousa I, Chaves LH, Barros Jr G. Uso de agrotóxicos impactando a saúde de horticultores familiares na região de Lagoa Seca-Paraíba. Engenharia Ambiental, Espírito Santo do Pinhal $2011 ; 8: 232-45$.

24. Vinha MB, Pinto CL, Pinto CM, de Souza CF, Souza MR, de Oliveira LL. Impactos do uso Indiscriminado de Agrotóxicos em Frutas e Hortaliças, 2013. Rev Bras Agrop Sust 2011; $1: 102-7$.

25. de Carvalho SL, de Almeida F, Lima EA. Avaliação das condições sócio-econômicoambientais de algumas propriedades agrícolas no município de Santa Rita do Passa QuatroSP. Periódico Eletrônico Fórum Ambiental da Alta Paulista 2012; 8:348-59.

26. Iwani A, Ferreira CP, Dinnouti LA, Bueno F, Araújo RM, Gonsalves T, et al. Manual de uso correto e seguro de produtos fitossanitários - agrotóxicos. 1a ed. São Paulo: Linea Creativa; 2010. 28 p.

27. Rigotto RM, Paixão e Vasconcelos D, Rocha MM. Pesticide use in Brazil and problems for public health. Cad Saude Publica 2014; 30:1360-62.

28. Rigotto RM, Carneiro FF, Marinho AM, Rocha MM, Ferreira MJ, Pessoa VM, et al. O verde da economia no campo: desafios à pesquisa e às políticas públicas para a promoção da saúde no avanço da modernização agrícola. Cienc Saude Colet 2012; 17:1533-42.

29. Vieira Filho JER, Gasques JG, de Sousa AG. Agricultura e crescimento: cenários e projeções. Brasília: Ipea; 2011.

30. Peres F, Moreira CJ. Saúde e ambiente em sua relação com o consumo de agrotóxicos em um pólo agrícola do Estado do Rio de Janeiro, Brasil. Cad Saude Publica 2007; 23 Sup 4:S612-21.

31. Brasil. Ministério da Saúde. Secretaria de Vigilância Sanitária. Manual de Vigilância da Saúde de Populações Expostas a Agrotóxicos. Organização Pan-Americana de Saúde/Organização Mundial de Saúde. Brasília: Ministério da Saúde; 1997.

32. Teixeira JR, Ferraz CE, Couto Filho JC, Nery AA, Casotti CA. Intoxicações por agrotóxicos de uso agrícola em estados do Nordeste brasileiro, 1999-2009. Epidemiol Serv Saude 2014; 23:497-508.

33. SINITOX - Sistema Nacional de Informações Toxico-Farmacológicas. Casos Registrados de Intoxicação Humana, de Intoxicação Animal e de Solicitação de Informação por Região e por Centro. Brasil; 2011. Disponível em: http://www.fiocruz.br/sinitox/media/Tabela\%201.pdf

34. SINITOX - Sistema Nacional de Informações Tóxico-Farmacológicas. Evolução dos Casos Registrados de Intoxicação Humana por Agente Tóxico. Brasil; 2011. Disponível em: http://www.fiocruz.br/sinitox/media/Tabela\%2010.pdf 
35. Rebelo FM, Caldas ED, Heliodoro VO, Rebelo RM. Intoxicação por agrotóxicos no Distrito Federal, Brasil, de 2004 a 2007 - análise da notificação ao Centro de Informação e Assistência Toxicológica. Cienc Saude Colet 2011; 16:3493-502.

36. Brasil. Ministério da Saúde. Secretaria de Vigilância Sanitária. Agrotóxicos X Saúde Pública. Departamento de Vigilância em Saúde Ambiental e Saúde do Trabalhador. Brasília: Ministério da Saúde; 2012.

37. Mostafalou S, Abdollahi M. Pesticides and human chronic diseases: evidences, mechanisms, and perspectives. Toxicol Appl Pharmacol 2013; 268:157-77.

38. Richardson JR, Roy A, Shalat SL, von Stein RT, Hossain MM, Buckley B, et al. Elevated serum pesticide levels and risk for Alzheimer disease. JAMA Neurol 2014; 71:284-90.

39. Brasil. Ministério da Saúde. Secretaria de Atenção à Saúde. Departamento de Ações Programáticas Estratégicas. Diretrizes para atenção integral à saúde do trabalhador de complexidade diferenciada: protocolo de atenção à saúde dos trabalhadores expostos a agrotóxicos. Brasília: Ministério da Saúde; 2006.

40. Biazon AC, Baccon BG. Exposição a agrotóxicos: perfil dos trabalhadores de uma comunidade rural de campo Mourão-PR. SaBios: Rev Saude e Biol 2014; 9:13-9.

41. Souza CS, Souza CCS, Vosgerau MZS. Conhecimentos e práticas na utilização de agrotóxicos e seu impacto na saúde de assentados de Jardim Alegre/PR. Divers@! 2013; 6:62-72.

42. Rambow C, Panichi VB, Figueiredo JA. Risco: a percepção da comunidade ribeirinha do Rio dos Sinos em relação ao uso de defensivos agrícolas. Rev Elet Ges, Edu Tec Amb 2014; 18:796-802.

43. Weisskopf MG, Moisan F, Tzourio C, Rathouz PJ, Elbaz A. Pesticide exposure and depression among agricultural workers in France. Am J Epidemiol 2013; 178:1051-8. 